\title{
LAOCOONTE, O SOBRE LOS LÍMITES DEL PERIODISMO Y LA LITERATURA*
}

\author{
Hans Christoph Buch
}

\begin{abstract}
¿Es posible narrar el horror? A diferencia de la literatura, ¿cuáles son los límites de la representación de la realidad que nos promete el periodismo? En este ensayo sobre el célebre Laocoonte, de G. E. Lessing (1766), H. C. Buch se refiere a su propia experiencia y
\end{abstract}

Hans Christoph Buch. Escritor, crítico literario y periodista. Nació en Wetzlar, Alemania, en 1944. Es uno de los autores alemanes contemporáneos más importantes de la generación de los llamados "veteranos del 68" (Altachtundsechziger). Estudió germanística, lenguas y literatura eslavas en Bonn y Berlín (Dr. Phil.). Vivió algún tiempo en África Occidental, América Latina y en Haití. Ha sido profesor visitante en universidades de Alemania, Estados Unidos, Hong Kong, Buenos Aires y Cuba. Como corresponsal de Die Zeit y Spiegel ha estado en numerosas zonas de conflicto, incluidas Bosnia, Chechenia, Haití, Algeria, Zaire, Camboya, Timor Oriental, Pakistán y Liberia. Entre sus publicaciones se cuentan las recopilaciones de sus reportajes, Tropische Früchte y Blut im Schuh, así como la colección de relatos y crónicas sobre América Latina recogidos en su Aus der neuen Welt, y sus novelas Kain und Abel in Afrika (sobre las masacres en Ruanda), Die Hochzeit von Port-au-Prince, publicada en 1984 (año en que fue distinguido como Officier de l'Ordre de l'Art et des Lettres por el Ministerio de Educación y de las Artes de Francia) y Wie Karl May Adolf Hitler traf und andere wahre Geschichten.

* "Laokoon oder Die Grenzen von Journalismus und Literatur", tomado del libro de Hans Christoph Buch, Blut im Schuh. Schlächter und Voyeure an den Fronten des Weltbürgerkrieges (Sangre en el zapato o pisadas de sangre. Matarifes y voyeures en frentes de la guerra civil mundial), Francfort/Meno: Editorial Eichborn AG, 2001. Su traducción al csstellano y reproducción en esta edición cuentan con la debida autorización del autor.

El texto "Laocoonte, o sobre los límites del periodismo y la literatura", columna vertebral del libro Blut im Schuh, se compone de cuatro partes, las que se reproducen aquí como un solo cuerpo. En el libro, sin embargo, ellas aparecen distribuidas en distintas secciones. En una edición anterior ( $\mathrm{N}^{\circ}$ 82, otoño 2001), Estudios Públicos publicó un extracto de la primera sección, la que ahora se publica en forma íntegra.

Traducción y notas explicativas de Ricardo Loebell. 
vivencias en zonas de conflictos bélicos. En base a un tramado que sigue la estructura del Laocoonte de Lessing, se entremezclan crónicas, narraciones literarias y episodios biográficos, así como reflexiones sobre los medios de comunicación, el periodismo literario, la responsabilidad ética del corresponsal y la conducta humana frente a la violencia.

RUPRECHT: Y si me enviasen al diablo en una nave, y tuviera que luchar con los caníbales en los mares del sur, ¡iría! A dos mil millas estaré bien. EvE: Hay guerra, piénsalo, vas a la guerra: ¿Quieres separarte de mí con ese rencor?

(Heinrich von Kleist [1777-1811]: El Cántaro Roto)

I

magínese que acaba de aterrizar en Dili, la capital de Timor Oriental, y se encuentra ante una camioneta abollada en cuya carga diez personas encadenadas unas a otras han sido rociadas con bencina y quemadas vivas: un grupo de Laocoonte ${ }^{\mathrm{i}}$ que no está hecho de mármol sino de carne humana carbonizada. Le ahorro a usted la imagen de los huesos que sobre-

${ }^{\mathrm{i}}$ El grupo escultórico de mármol del Laocoonte, que da título a la obra de Lessing (Gotthold Ephraim Lessing: Laocoonte o sobre los Límites de la Pintura y la Poesía, Berlín, 1766), a la que Hans Christoph Buch se remite en su obra, fue hallado en el año 1506 en unas excavaciones efectuadas en Roma. Al parecer el hallazgo tuvo lugar en el mismo sitio que ocupó el grupo en tiempo del emperador Tito.

La obra se atribuye al escultor griego Agesandro de Rodas, con quien colaboraron sus hijos Polidoro y Atenodoro, realizada a partir de un bloque único. En ella se representa al sacerdote troyano Laocoonte y a sus dos hijos en el momento de morir bajo los efectos de las mordeduras venenosas de dos serpientes enroscadas en sus cuerpos. Esta muerte, según la leyenda, es el castigo impuesto al sacerdote y a sus hijos por no haber compartido Laocoonte el entusiasmo de los troyanos ante el simulado levantamiento del sitio por parte de los griegos, y haber desconfiado del regalo del célebre caballo de madera que éstos hicieron a aquéllos.

En el grupo escultorio se exageran los efectos teatrales del dolor con excesos en la anatomía. El subtítulo del libro de Lessing: "Sobre los límites de la Pintura y la Poesía", indica la intención de restablecer dichos límites, que los críticos en su tiempo se esforzaban por suprimir entre las dos artes. Cfr. el prólogo de Enrique Palau en su traducción del Laocoonte de G. E. Lessing (Barcelona: Editorial Iberia, 1957), p. 25s. (N. del T.) 
salen de la carne, así como el hedor dulzón que recuerda a las fiestas de asado a la parrilla; preferiría hablar de las flores y las monedas que los pobladores esparcen sobre las cenizas para apaciguar los espíritus de los asesinados. Es más consolador.

¿Usted dice que no se lo podría imaginar, pues Timor Oriental esté demasiado lejos?

Esta excusa no vale, Dili se halla a tan sólo dos o tres horas de vuelo de su lugar de vacaciones preferido, Bali o las Maldivias. Bajo el signo de la globalización, ya no hay más islas lejanas y todos los puntos del globo se acercaron virtualmente a su domicilio. A pesar de esto voy a admitir su excusa: dice que no tiene tiempo ni dinero para volar a Darwin en Australia y acreditarse junto a la UNAMET o INTERFET ${ }^{\mathrm{ii}}$ —así se llaman las tropas de Cascos Azules enviadas a Timor Oriental—, y después seguir a Dili en un avión militar, lo que no le costaría nada si tiene una credencial de prensa o trabaja para una organización humanitaria. Pero antes tendría que solicitar una visa indonesa, lo que puede demorar mucho, pues Timor Oriental pertenece aún de jure, pero no de facto, a Indonesia. Y no le quiero ocultar que la comunicación allí es difícil, porque ya no se habla ninguna lengua europea, sólo timoreses de mayor edad comprenden el portugués, y los jóvenes, es decir, la mayoría de la población, hablan sólo bahasa indonesia y tetum, idiomas locales. Además en Dili no hay hoteles ni restaurantes, ni agua ni electricidad, en cambio hay mosquitos y cocodrilos de agua salada que hacen riesgoso un baño de mar. Aún así, la probabilidad de ser devorado por un cocodrilo es mucho menor que la de ser alcanzado por la bala de un rebelde pro indonés, e incluso mucho menor que la de contraer tifus o malaria. Con tal objeto, veamos una vez más el siguiente diálogo de El Cántaro Roto de Kleist, que trata precisamente de aquella región del mundo:

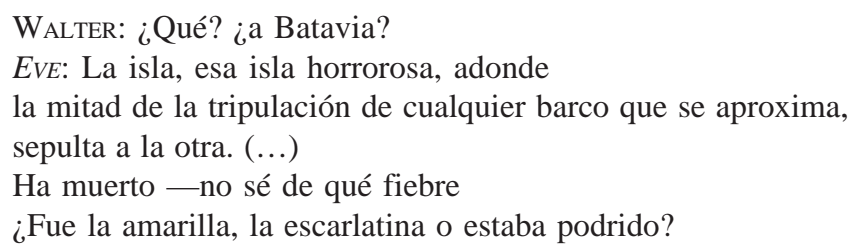

¿Y si nosotros fuésemos en su lugar a Kosovo? Priština se halla tan sólo a dos horas de vuelo de Viena o Berlín; si usted quiere, puede ir en auto. La moneda es la misma que en Alemania, pero su poder de compra es mayor que en la República Federal y para ingresar no se requiere más que la cédula de identidad. Imagínese que acaba de llegar a Gjakovë, que en serbio se llama Djakovica, y se encuentra con una fosa común que abren en su

\footnotetext{
${ }^{\text {ii }}$ Véase lista de siglas y abreviaciones al final del texto (N. del T.).
} 
presencia. De la tierra fresca removida se distingue una manga vacía por la que se arrastra un gusano. Y el nativo que lo acompaña dice más bien incidentalmente que ésa es la chaqueta de su hermano, acribillado por policías serbios y que fue enterrado secretamente junto a otros asesinados en el huerto, antes de que las autoridades pudiesen hacer desaparecer los cadáveres. Más tarde, en el camino por el antiguo casco musulmán de la ciudad, lleno de muescas y fisuras por los impactos de artillería, el lugareño indica una ruina ennegrecida por las bombas incendiarias y me dice que es su casa; solamente el Porsche traído de Alemania, adquirido con su dinero de trabajador inmigrante, ha sobrevivido a la guerra, escondido bajo una pila de heno.

Usted le ofrece un cigarrillo, su guía lugareño lo rechaza agradecido a pesar de que hace tres meses que no ha fumado Marlboro, como él dice. Usted le quiere regalar todo el paquete, pero él opina que es un regalo muy valioso, aceptando con resistencia un solo cigarro que guarda en el bolsillo de la camisa para fumárselo más tarde. Después lo conduce al antiguo cuartel general de la policía, un bloque de concreto de varios pisos, en el que un cohete teledirigido de la OTAN — cruise missile o tomahawk- abrió un profundo agujero en la fachada. La caja de la escalera ha quedado intacta y usted se trepa por sobre montones de escombros y vigas metálicas desencajadas para llegar a una oficina en el piso superior, en cuyo escritorio se acumulan fichas con fotografías e impresiones digitales de individuos buscados, y al lado, como en una mala película, una botella de slibovitz medio vacía y una revista pornográfica deshecha. "Éste", dice su guía, sacudiendo la ceniza de una ficha polvorienta, "fue un primo mío torturado a muerte en el sótano de la comisaría. Sin embargo, él no tenía nada que ver con la UÇK”.

$\mathrm{Al}$ abandonar el edificio, usted se ve rodeado por mujeres con lágrimas en el rostro que alzan las fotografías de sus esposos, hermanos e hijos secuestrados por la milicia. Una madre le pide a usted ayuda para buscar a su hijo de quince años que desapareció hace seis semanas sin dejar huellas. A usted le cuesta hacer comprender a la mujer que no es un miembro del Alto Comisariado de las Naciones Unidas para los Refugiados, UNHCR, ni de la Cruz Roja, y se siente entonces bastante miserable.

Al llegar a este punto usted protesta y quiere saber por qué expongo delante suyo toda la miseria del mundo. Desde luego, aunque lo quisiera, usted no podría hacer nada porque simplemente escapa a su influencia y, además, es "nieve de antaño". En su condición de auditor o lector, ¿¿cómo podría reaccionar si no es entrando en shock y sintiendo vergüenza, rabia de impotencia y consternación? Si al menos se le pidiera una donación para 
aliviar la miseria más agobiante, pero ¿de esta manera? A mi pregunta retórica de si acaso no siente curiosidad por el estado del mundo en el que vive, usted me responde indicando que su receptividad al sufrimiento ajeno es limitada y me da a entender que tiene suficiente con sus propios problemas, que prefiere un amor práctico al prójimo a un amor abstracto, impracticable desde la distancia, que no compromete en nada al autor de las buenas palabras y que sólo sirve para hacer alarde de buena conciencia. Sin embargo, hay una objeción que lo hace pensar: lo que sucede en otra parte, ¿̇no podrá ocurrir mañana o en un futuro remoto delante de su propia casa? La ciudad de Prizren, donde el jefe subrogante de la policía, Milan Petroviæ, según los informes de investigadores de la ONU ha torturado a muerte a civiles kosovares, está a una distancia de una hora y media de vuelo de Munich.

Éste es el primer día de la intervención de la OTAN y el Tribunal Internacional de derechos humanos de La Haya no ha enviado aún observadores a Kosovo. Recién hace una hora, unidades blindadas de vanguardia de la Bundeswehr (Fuerzas Armadas Alemanas) cruzaron la frontera albanesa cerca de Kukës y están acercándose lentamente a los distritos periféricos de Prizren, donde el jefe subrogante de la policía no descarga esta vez su ira con los habitantes del lugar, sus víctimas habituales, sino con dos periodistas que esperan en el check point (el puesto de control) intentando llegar al centro de la ciudad. Al reportero de Buenos Aires que me acompaña, el policía le arranca de la mano su credencial de la OTAN y la pisotea con el taco de sus botas. Cuando el argentino protesta gritándole "hijo de puta" [sic] el jefe de la policía se enfurece — como le ocurre al enano saltarín ${ }^{\mathrm{iii}}$ al escuchar por primera vez su verdadero nombre- y le encañona el arma cargada sobre el pecho. Temo por la vida del argentino y trato de calmarlo. Éste, con la punta de los dedos, como si se tratara de un objeto repugnante, aparta el cañón del fusil hacia un lado, pero la cólera del policía no se apacigua, por el contrario, muestra los colmillos como un perro de combate que está a punto de abalanzarse sobre su víctima.

En ese momento de angustia la salvación llega con el ruido estruendoso de una caravana de vehículos militares alemanes; tanques Leopard con soldados sudorosos y sonrientes nos saludan con muecas desde la torre del tanque, como si percibieran en esta escena un mal entendido o una broma. Bajo el ruido ensordecedor, nos envuelve una nube de gases de escape. Cuando el polvo se disipa, ya hemos cruzado el lugar de control

iii Se refiere al enano Rumpelstilzchen, del cuento de los hermanos Grimm Rumpelstilzchen (publicado en 1812), quien intenta llamar la atención de una manera furibunda e impertinente, tratando de compensar así su baja estatura física y humana (N. del T.). 
agazapados al resguardo del convoy, y logrado burlar a nuestro guardia que tose y maldice sacudiéndose la tierra del uniforme.

De noche, durante la conferencia de prensa en la antigua sede de la OSCE, que sirve ahora de cuartel del Estado Mayor, el comandante general habla de un éxito rotundo. El contingente alemán de la OTAN ha llegado conforme a Prizren y, pese a la tensa situación, no hubo saqueos ni disturbios. En ese momento aún no sabemos que dos reporteros del semanario Stern y su intérprete han sido acribillados por francotiradores al norte de Prizren.

“¿Por qué hace esto?, ¿por qué se pone voluntariamente en peligro, señor Buch?” No puedo responder más que con una sonrisa embarazosa a esta pregunta recurrente; porque no lo sé con exactitud. Actúo por un motivo que yo mismo no comprendo muy bien. No se trata de entusiasmo patriótico ni de convicción política, aquella fuerza moral que en otros tiempos incitó a los intelectuales de izquierda a integrarse a la Guerra Civil española o a la campaña de los aliados contra Hitler. No soy un soldado de primera línea como Ernst Jünger, ni un veterano como Hemingway, cuya pueril idea de macho se nutría de sus experiencias de guerra y caza. Soy un observador pasivo, que sin intervenir en los sucesos tomo partido apasionadamente: una contradictio in adiecto que debo aceptar tal cual. Por cierto lo que corresponde aquí es el espíritu aventurero, pero la palabra curiosidad lo describe mejor: curiosidad por la condition humaine después del fin de la Guerra Fría. Quiero saber cómo viven mis semejantes a comienzos del siglo XXI y de qué mueren; también tengo curiosidad conmigo mismo. Enfrentándome a situaciones extremas intento averiguar algo sobre mí mismo.

Lo que me interesa muy poco es lo que aparece en los diarios, aquello masticado y vuelto a masticar que luego se devuelve y derrama por todos los canales de televisión. La pregunta de si los medios manipulan nuestra percepción y cómo, me interesa sólo marginalmente. "En la guerra, más que en cualquier otro lugar del mundo, las cosas se dan de manera distinta a como uno las imagina, y es muy diferente verlas de cerca que a la distancia”, escribe Clausewitz. La realidad es más brutal de lo que muestra la televisión (las peores imágenes se ahorran a los espectadores) y, al mismo tiempo, menos grave, porque no se mata y se muere en todas partes a la vez. De todas maneras, batallas materiales como las de la Primera o la Segunda Guerra Mundial (o la Guerra del Golfo) no las viví. Conocí únicamente la llamada low intensity war (guerra de baja intensidad) que destruye mercados en vez de fábricas y cabañas en vez de palacios, con la excepción de la capital chechena, Grozny, cuya destrucción, sin embargo, no provocó en 
los medios una indignación comparable al evitable ascenso de Haider, el populista de derecha austriaco. La censura y la manipulación no sólo aparecen en la forma de comentar los sucesos, sino también en los preliminares, cuando se decide sobre qué parte del mundo, dónde y cuán exhaustivo se hará un reportaje.

Aún a mediados de los años 80, reportajes en vivo del Khmer Rojo en Camboya o de los boieviki en Chechenia, entonces parte integrante de la Unión Soviética, eran técnica y políticamente imposibles. Cuando vi el aparato de telex antediluviano en la embajada de la antigua RDA en Buenos Aires, al que sólo colaboradores de la Stasi tenían acceso, comprendí por qué el Pacto de Varsovia perdió la Guerra Fría. Hoy día, computadores, fax, teléfonos satelitales, transmiten en fracción de segundos textos e imágenes de un punto del planeta a otro, burlando sin esfuerzo cualquier control y censura oficial. El reverso del progreso tecnológico son los reporteros que no saben nada de la historia y la cultura del país al que llegan, y menos conocen o hablan su lengua. Tampoco es necesario, porque todos los hechos y datos se almacenan en sus computadores, y el texto que redactan rara vez es más largo que un pie de foto. El productor de palabras se transforma en asistente del fotógrafo, que es mejor pagado y por tanto irremplazable; buenos fotógrafos son escasos, pero proveedores de texto hay como arena en el mar, el newspeak lo denomina "printmedia".

Lo contrario del reportero es el experto al que no le gusta abandonar su oficina; en lugar de ir al frente de combate, va a la biblioteca o desciende un piso más abajo, al archivo. En congresos internacionales brilla por un conocimiento específico que encarga recopilar a sus estudiantes y preparar a su asistente, antes de entregárselo al gobierno. Junto a él ha aparecido un nuevo tipo que se puede encontrar hoy día en todas las regiones en crisis: el reportero con mochila, periodista equivalente al turista mochilero, casi siempre un estudiante de Canadá o Estados Unidos, que con laptop y cámara de video se interna en el país en guerra y vive en constante peligro de ser arrestado o fusilado como espía, porque nadie le cree que quiere reunir material para su tesis de magíster. A alguien como yo, armado tan sólo con un lápiz y un block de apuntes, le va mejor: los combatientes de ambos bandos lo toman a uno como un sacerdote o médico que puede sanar sus dolencias físicas y espirituales, mientras los reporteros de televisión se burlan condescendientemente, como si uno fuera una reliquia de la época de Gutenberg.

Pero no soy periodista sino escritor de profesión, y tampoco soy el primer autor que ha ido voluntariamente a una guerra, sin estar obligado, por fuerza mayor o por el Estado, como suele suceder. Desde mediados de 
los años 90 fui enviado por el semanario Die Zeit y otros medios a numerosos territorios en crisis o en guerra: Liberia, Sierra Leona, Burundi, Ruanda, Bosnia, Chechenia, Argelia, Kosovo, Camboya, Pakistán y Timor Oriental, no como reportero profesional sino como escritor. Aquí está la respuesta a la pregunta formulada anteriormente: hay desafíos existenciales que un escritor debe asumir si quiere averiguar algo sobre sí mismo y el mundo que lo rodea que no haya sabido antes. Me refiero a situaciones extremas como el nacimiento y la muerte, la prisión y el exilio, la tortura y la guerra, experiencias que no se pueden imaginar y que por lo tanto no son posibles de intuir en el escritorio, sino sólo alejándose del escritorio y exponiéndose. La literatura lo ha hecho en todos los tiempos.

En el verano de 1851, el conde León Nikoláievich Tolstoi viaja al Cáucaso. En vísperas de cumplir veintitrés años, el 28 de agosto (cronología antigua), se desahoga anotando en su diario de vida: "He tenido mujeres, me he mostrado débil en muchas ocasiones, en el simple trato con las personas, en el peligro, en el juego de naipes, y aún estoy lleno de falso pudor. He mentido mucho. Dios sabrá para qué he venido a Groznaia”.

Groznaia, llamada así según Iván el Terrible, actualmente Grozny, fue el escenario de una guerra que duró décadas, rebrotando casi sin tregua una y otra vez. En compañía de su hermano mayor, Tolstoi emprendió un penoso y peligroso viaje a sus expensas para participar como observador en una expedición militar del ejército ruso contra los insurgentes chechenos. Aun cuando jamás haya servido al ejército y no entienda nada de asuntos militares, sueña con una carrera de noble oficial; al mismo tiempo quiere ser escritor y reunir material para un cuento o una novela sobre la guerra del Cáucaso. A la pregunta de Tolstoi, de si puede incorporarse a su regimiento, le responde el oficial de servicio, capitán Chlopov: "De permitírselo yo, sí puede. Pero mi consejo sería que se abstuviera. ¿Para qué correr ese riesgo?” Y le recomienda la lectura de una obra clásica sobre la guerra que describe en detalle dónde se ubicaba cada cuerpo del ejército y cómo se desarrolló cada batalla. Precisamente eso, dice Tolstoi, no le interesa. "Bueno, ¿entonces qué? ¿Quiere ver sólo cómo se mata a la gente?” No, responde Tolstoi, y plantea una pregunta, que aún hoy, 150 años después, sigue sorprendiendo por su ingenuidad: él quiere saber qué significa el coraje, por qué los soldados van a combatir y a morir. "Prueba de coraje, dice el capitán Chlopov, muestra aquel que se comporta como corresponde"; sentencia que Tolstoi consigna en su diario de vida porque la encuentra más convincente que la definición de Platón, para quien el coraje consiste en "saber aquello que es de temer y aquello que no", lo que le parece muy abstracto.

Tolstoi acompaña al ejército ruso en una expedición punitiva, en la que saquean e incendian un pueblo montañoso (aúl) checheno: los habi- 
tantes son masacrados por los soldados. Dos cosas irritan a Tolstoi: el hecho de que a pesar de estar asignado al Estado Mayor no logra tener una visión general de la operación —las maniobras del ejército le hacen pensar en un hombre que gesticula en el aire con un hacha. Y que el comandante, el príncipe Bariatinski, dé incidentalmente la orden de destruir el pueblo, como si se tratase de mandar a poner la mesa en una recepción de palacio. “ ‘Pues ahora, coronel, la gente puede incendiar y saquear; ya veo que tienen unas ganas terribles de hacerlo', dice sonriente”.

El cuento de Tolstoi, La Incursión, escrito bajo la impresión inmediata del suceso, es inmaduro desde el punto de vista literario. Basado en las notas de su diario de vida, se lee como el informe de un corresponsal de guerra al que le falta la distancia necesaria. Recién diecisiete años más tarde, en su obra principal La Guerra y la Paz, el autor escribirá una novela a partir de sus experiencias acumuladas en el Cáucaso, refundiéndolas en una composición literaria transfigurada. El protagonista de la novela es Pierre, un civilista que, como el joven Tolstoi, no entiende nada de la estrategia militar y deambula sin rumbo entre muertos y moribundos por los campos de batalla de Borodino, con una mirada extraña que revela mejor la crueldad del combate que todo el conocimiento de un especialista. Se sabe que $L a$ Guerra y la Paz es una epopeya histórica que se desarrolla en la era napoleónica. Tolstoi necesitó otros treinta años para presentar en estado puro la experiencia traumática de su juventud, la guerra de Cáucaso, en la obra tardía Hadji Murat. De estas experiencias que abarcan toda una vida nace la gran literatura; frente a la guerra desatada hoy día en Chechenia es evidente la actualidad de la novela escrita hace cien años: "Sado fue con picota y pala en mano, acompañado de parientes, a cavar la tumba para su hijo. El anciano abuelo, sentado junto al muro de la casa destruida, tallaba mecánicamente la corteza de una varilla con la mirada perdida. (...) Lamentos de mujeres se oían desde todas las casas y de la plaza, adonde habían llevado a otros dos muertos. Los pequeños lloraban con las madres. El ganado bramaba hambriento, pero no había más forraje. Los niños más grandes dejaban de jugar y miraban con ojos asustados a los adultos”.

El sufrimiento sin solución no inspira compasión sino repulsión, así define Lessing el pensamiento fundamental de su Laocoonte: "Imaginad a Laocoonte con la boca abierta y juzgad, ahora dejadle gritar y veréis el efecto. Antes era una imagen que inspiraba compasión, porque encarnaba belleza y dolor a la vez; ahora es una figura fea, horrible, que nos fuerza a apartar la mirada, porque el espectáculo del dolor nos desazona hasta tal 
punto que ni la belleza del objeto sufriente puede transformar esta destemplanza en un apacible sentimiento de compasión"1, iv .

El Laocoonte de Lessing no es una consideración clásica sobre la nobleza de la simplicidad y la grandeza silenciosa del arte antiguo, ni como dice su promisorio subtítulo, un tratado académico sobre "los límites de la pintura y la poesía”; es más bien un ensayo sobre la representabilidad del sufrimiento y el dolor físico, de la crueldad y la violencia. A eso apunta la problemática esbozada en sus páginas, y a algo más, ya que el autor no confronta al lector con conceptos cerrados, sino que lo integra en un proceso de pensamiento haciéndolo participar en la creación de su texto.

Lessing distingue entre testigos oculares inmediatos de un suceso, a los que denomina asistentes, y observadores, es decir, el público. Entre ambos está el narrador o cronista, cuyo rol está representado hoy en día por el reportero. Es imposible que entre todos ellos haya empatía, no por falta de buena voluntad sino por incapacidad de ponerse en el lugar del otro; un mecanismo psicológico que no se puede confundir con la indiferencia, pues sirve ante todo para la autoprotección: la eliminación de la distancia exterior pone en peligro el equilibrio interno.

Por otra parte, el dolor físico no es susceptible de despertar en nosotros la misma compasión que nos inspiran otros sufrimientos. La imaginación percibe una parte tan pequeña del dolor ajeno, que su simple vista no puede evocar un sentimiento recíproco. (...) Y, entonces, ¿quién sabe si los dramaturgos modernos son más dignos de elogio que de vituperio, por haber evitado del todo este escollo, o al menos haberlo franqueado con su ligera embarcación?v

La observación de Lessing se me confirmó al regresar de territorios en crisis o en guerra. Tan pronto yo respondía a la pregunta de quien me interpelaba: “¿Cómo era en Ruanda? o ¿cómo era en Camboya?”, su ceño se fruncía en arrugas dolorosas que decían mucho más que las expresiones "terrible" o "grave". Por lo visto, lo que yo intentaba dar a conocer sobrepasaba la empatía de mis auditores, cuya imaginación no alcanzaba a trasladarlos a un campo de refugiados. Pero ellos sí tenían curiosidad por saber cómo era el clima en Ruanda o Camboya y qué se comía, es decir, utilizando como criterio sus experiencias de vacaciones hacían mensurable lo incon-

\footnotetext{
${ }^{1}$ Gotthold Ephraim Lessing (1729-1781), Laokoon. Über die Grenzen der Malerei und Poesie (Berlín, 1766).

iv Para la traducción al castellano se tuvo a la vista la traducción de Lessing realizada por Enrique Palau: Laocoonte o sobre los Límites de la Pintura y la Poesía (Barcelona: Editorial Iberia, 1957), p. 46 ( $\mathrm{N}$ del T.)

${ }^{\vee}$ G. E. Lessing, Laokoon. Traducción basada en la de Palau, p. 58. (N. del T.).
} 
mensurable. Frente a eso no hay nada que objetar. Lo que más me asombró fue el hecho de que las víctimas de crisis y/o guerras no querían saber nada del sufrimiento de otras personas en distintos lugares del mundo, aun cuando se trataba, como en Bosnia o Chechenia, de sus correligionarios musulmanes. Al contrario, mientras más me aproximaba a un territorio en guerra, menor era la capacidad de la población de admitir la miseria ajena, pues los sobrevivientes — víctimas, ejecutores y espectadores- estaban totalmente absorbidos (y frecuentemente sobrepasados) por la asimilación de su propio sufrimiento. Esto no es de extrañar.

La compasión activa presupone una existencia material asegurada; al finalizar la guerra, hubo limitada empatía hacia los judíos perseguidos y asesinados, incluso entre los soldados que regresaban y entre la población civil de las ciudades alemanas que habían sido bombardeadas. Esto no ocurría solamente por la propaganda antisemita de los nazis, que surtía efecto incluso en sus adversarios. También los aliados recibían con incredulidad los informes de fugitivos de los campos de concentración, y los sobrevivientes necesitaron años o décadas para llevar sus experiencias traumáticas al papel. Después de 1945, la prioridad fue asegurar la existencia, reunir a las familias dispersas, buscar un techo y procurarse el pan cotidiano. Los primeros testimonios publicados poco después del fin de la guerra sobre los crímenes nazis - Der SS-Staat (El estado SS) de Eugen Kogon, y Medizin ohne Menschlichkeit (Medicina sin humanidad) de Alexander Mitscherlich — no provocaron en la población la catarsis esperada ni consiguieron la desnazificación. Tampoco los procesos de Nuremberg contribuyeron a una reorientación verdadera del pensamiento. Incluso entre los antifascistas los informes de esta índole se calificaban como “cuentos atroces"vi, y entre los escritores del Grupo 47vii imperó por mucho tiempo el dogma de que el genocidio de los judíos no podía

vi Término empleado por los nazis para desacreditar la denuncia de sus crímenes. Cfr. Hans Christoph Buch, Archipel de la Douleur. Voyages au bout du Nouveau Désordre Mondial, trad. Nicole Casanova (París: Bernard Grasset, 2003), pp. 25 y 347 (N. del T.).

vii El Grupo 47 (Gruppe 47) era un conjunto informal de autores y críticos alemanes que tenía por objetivo revitalizar la literatura alemana de posguerra. Sus orígenes se remontan a 1946, cuando Alfred Andersch y Walter Kolbenhoff fundaron en Munich la revista literaria Der Ruf (La llamada). Su objetivo era informar y enseñar al público alemán sobre la democracia tras el fin del nazismo. Las fuerzas de ocupación norteamericanas les revocaron la licencia tras acusarlos de nihilistas. Más tarde, inspirándose en la Generación del 98, que había propugnado una transformación cultural y social de España tras la pérdida de las colonias en 1898, fundaron el Grupo 47 en torno a Hans Werner Richter. El grupo se reunía con regularidad dos veces al año y jóvenes autores leían sus manuscritos inéditos. En cada encuentro, se otorgaban premios literarios a autores todavía desconocidos, comenzando en 1950 con Günter Eich y luego, sucesivamente, Heinrich Böll, Ilse Aichinger, Martin Walser y Günter Grass. Debido a diferencias sobre la manera de entender la literatura y la política, el grupo se disolvió en 1977 (N. del T.). 
ser representado de forma artística porque rompía con el marco de la literatura. A pesar de que la Todesfuge (Fuga de muerte) de Paul Celan ya había rebatido la sentencia de Theodor W. Adorno de que después de Auschwitz sería una barbarie escribir poesía. Hubo que esperar hasta mediados de los años 60 para que el oratorio de Auschwitz de Peter Weiss, Die Emittlung (El Sumario), basado en el proceso de Francfort, provocara un cambio repentino en la opinión pública y se concretara, políticamente, con la genuflexión de Willy Brandt en el ghetto de Varsovia y la construcción de un monumento a las víctimas del Holocausto. La emisión de la serie televisiva con el mismo nombre, el filme de Steven Spielberg La Lista de Schindler, el debate histórico y la discusión en torno a las hipótesis de Daniel Goldhagen ${ }^{\text {viii }}$ fueron otros avances.

Desde entonces han surgido variados textos literarios sobre el Holocausto, no sólo de parte de los sobrevivientes, víctimas, ejecutores y observadores, sino de las generaciones posteriores. Más allá de simples testimonios, se han utilizado todas las formas y variedades artísticas: desde la historieta ilustrada hasta el teatro musical, desde el teatro documental hasta la comedia trágica, desde el diario íntimo hasta la novela. Sin embargo, la advertencia de Lessing en el sentido de no franquear el escollo con una embarcación demasiado ligera, sigue teniendo vigencia. En efecto, mientras más se cruza el umbral de inhibición que impide, por ser irrepresentable, representar aquello que ocurrió antes — la muerte en la cámara de gas - y se hermosea artísticamente en cualquier dirección, más se pierde el impulso original, mezcla de mudo estupor, vergüenza y shock. Quitarles a estos temas su carácter tabú va de la mano con su banalización. Auschwitz se transforma en una referencia entre otras y la indignación ritualizada se petrifica, como todo bien cultural devaluado y convertido en un cliché que nada dice. Probablemente Martin Walser hizo alusión a esta tendencia cuando desató su controvertida polémica contra la instrumentalización del Holocausto $^{\text {ix; }}$ controvertida, porque, al tirar al bebé junto con el agua de la bañera, le atribuye a la moral individual un valor superior que al discurso

viii En 1996 el historiador norteamericano Daniel Jonah Goldhagen publicó el libro Hitler's Willing Executioners (versión en castellano, Los Verdugos Voluntarios de Hitler, Madrid: Taurus, 1997). Goldhagen sostiene ahí que los alemanes, debido al arraigado antisemitismo en su cultura (así como en la Iglesia católica), serían los ejecutores de la Shoah. El exterminio de judíos no habría sido posible sin el consentimiento de todos los sectores de la población alemana. Estas hipótesis desataron controversias incluso en la academia alemana (N. del T.).

${ }^{\text {ix }}$ Cfr. Martin Walser, Erfahrungen beim Verfassen einer Sonntagsrede (Experiencias al redactar un discurso dominical). Discurso pronunciado durante la entrega del Premio de la Paz de Editores y Libreros Alemanes en Frankfurt/M, 1998 (N. del T.). 
moral público, definiendo la elaboración del pasado como asunto personal; el camino enigmático que conduce hacia el interior ${ }^{\mathrm{x}}$.

No era el primer muerto que yo había visto en Haití, pero éste se grabó de manera más profunda que los otros en mi memoria. No parecía dormir, como lo quisiera el cliché misericordioso. En sus ojos desorbitados se había plasmado el último horror de lo que le había ocurrido. Probablemente, al volver de una discoteca cayó en manos de una patrulla del ejército que se dedicaba a la cacería nocturna de adversarios, verdaderos o imaginarios, del régimen militar. Los barrios pobres, en la ruta que conduce al aeropuerto, eran reductos del presidente Aristide, elegido democráticamente. Los paramilitares lanzaban los cadáveres sobre un montón de basura al borde del camino, donde permanecían para amedrentamiento, y los pobladores no se atrevían a enterrarlos por temor a las represalias de la policía.

Cuando veinticuatro horas más tarde volví a ver el cadáver, ya no estaba de espaldas sino de vientre. Los ladrones lo habían despojado de sus zapatos y los perros vagabundos o cerdos que rondan libremente en los barrios pobres de Haití, habían desviscerado el cuerpo arrastrándolo al otro lado de la calle. Prefiero no describir la imagen. Con justa razón Alex

${ }^{x}$ Cfr. Novalis, Werke, Tagebücher und Briefe Friedrich von Hardenbergs, editado por Hans Joachim Mähl (Darmstadt, 1999), p. 233. Véase también Novalis, Heinrich von Ofterdingen, editado por Jochen Hörisch (Frankfurt am Main, 1982).

Esta idea también la expresa el filósofo alemán Heinrich Rickert (1863-1936): "Tenemos un conocimiento inmediato de la realidad tan pronto dirigimos la mirada hacia nosotros mismos. El camino enigmático que conduce hacia el interior, revela el enigma universal. Más allá de ir objetivando en torno a las cosas, debemos ir directamente a su interior; el portón que debemos cruzar para este propósito se encuentra únicamente en el Yo" ("Wir haben eine unmittelbare Erkenntnis der Wirklichkeit, sobald wir nur den Blick auf uns selbst richten. Nach innen geht der geheimnisvolle Weg, der das Weltgeheimnis entschleiert. Wir dürfen nicht objektivierend um die Dinge bloß herumgehen, sondern wir müssen mitten in sie hinein, und die Pforte, die wir zu diesem Zwecke zu durchschreiten haben, liegt allein im Ich.”), Heinrich Rickert, Vom Begriff der Philosophie, Philosophische Aufsätze (Mohr Siebeck UTB, 2078), p. 5 y siguientes, el destacado es nuestro.

Una formulación menos metafísica y quizá más concreta de esta idea aparece cuando Carl Schmitt, en 1938, después de haber tenido que renunciar a sus cargos públicos y haberse escapado a último momento de la tropas de la SS, dice: "Si la autoridad pública tan sólo quiere ser pública, y si el Estado y su adhesión al credo remiten la fe a lo privado, entonces el alma de un pueblo se dirige al 'camino enigmático' que conduce hacia el interior" ("Wenn aber wirklich die öffentliche Macht nur noch öffentlich sein will, wenn Staat und Bekenntnis den innerlichen Glauben ins Private abdrängen, dann begibt sich die Seele eines Volkes auf den 'geheimnisvollen Weg', der nach innen führt”, schrieb Carl Schmitt 1938, nachdem er alle seine öffentlichen Ämter hatte aufgeben müssen und dem Zugriff der SS nur mit knapper Not entronnen war"), en Martin Tielke, Der stille Bürgerkrieg. Ernst Jünger und Carl Schmitt im Dritten Reich (Berlin: Landtverlag, 2006) (N. del T.). 
Webb, el fotógrafo que me acompañaba, capturó solamente sus pies desnudos.

Extrañamente, no me hice ninguna de las preguntas que vienen a la mente del lector de periódicos o espectador de televisión, aquellas que el comentario del conductor o el pie de foto tienen que responder de forma clara y concisa: cómo se llamaba el joven, qué profesión ejercía, cómo y por qué fue asesinado. No se trata de que estas preguntas no me interesen, pero me parecieron banales en presencia de aquella vida humana que había encontrado un final tan brutal. Mientras los transeúntes se tapaban la nariz con pañuelos y contemplaban al muerto, mirando furtivamente a su alrededor antes de continuar su camino, me vino a la mente un verso de mi profesor Walter Höllerer que expresa mejor que cualquier crónica la congoja existencial de la situación: "Yacía sin esfuerzo a la vera / del camino". Aun cuando el poema de Höllerer no haya nacido bajo el sol tropical de Haití sino bajo el hielo y la nieve durante la retirada de la Wehrmacht ${ }^{\mathrm{xi}}$ alemana a través de un paso de los Alpes italianos, se aproxima más al suceso que un comentario que se afana por ser objetivo. En el muerto anónimo, Höllerer no ve tan sólo un soldado caído sino a un hermano: "No era un esclavo; no, era un hermano mío el que murió", dice Antígona y Creonte le responde: "El enemigo nunca es amado, ni aun en la muerte”. Años más tarde, cuando leí la tragedia de Sófocles comprendí que, sin saberlo, yo había asistido a una escena primigenia de la humanidad. Pero todavía no me daba cuenta de eso, cuando, frente al muerto anónimo, recordaba el poema de Höllerer.

El poeta se había hecho consciente — con una autenticidad difícilmente descriptible - de que él podría haber sufrido el mismo destino. Cuando no se tiene conciencia de eso, el texto se vuelve frívolo o banal, independientemente de si el muerto es celebrado como mártir o lamentado como víctima de una matanza absurda. Esto no es sólo una cuestión de estilo, sino de distancia espacial: desde el escritorio del editor o desde el podio del orador oficial, la inmediatez no es la misma que cuando a uno le llega el olor de la putrefacción a la nariz. Quien ha respirado el hedor de la muerte no se puede librar más de él, y cuando ve a alguien teorizar realidades que no ha vivido en carne propia, y cuyas palabras son por lo tanto palabras vacías,

${ }^{x i}$ Wehrmacht (1935-1945) es el nombre que recibieron las fuerzas armadas alemanas, hasta entonces llamadas Reichswehr (1921-1935), surgidas en 1935 tras la disolución de la Reichswehr por el régimen nazi. La actual Bundeswehr, sin embargo, no se considera como su sucesora ni sigue tradiciones de ninguna organización militar alemana anterior (N. del T.). 
siente una especie de furia divina, no importa si en esa conceptualización se exalta la guerra y la violencia o se la condena con henchida indignación.

Podría citar aquí a Heiner Müller, Botho Strauß, Rainald Goetz y otros autores que coquetean a gusto con imágenes de violencia, pero prefiero darle la palabra a uno más versado como George Orwell, cuya crítica al espíritu del tiempo de los tardíos años 30 se nutre de una experiencia semejante. Orwell sabía de lo que hablaba cuando reprochaba al entonces joven poeta W. H. Auden su glorificación de la violencia de tendencia fascista. Aun cuando -0 porque Auden se hallaba al otro lado de las trincheras - en el campo del estalinismo, lejos de mejorar, la cosa empeoraba: "Tomorrow for the young, the poets exploding like bombs, / Tomorrow the bycicles races / Through the suburbs on summer evenings. But today the struggle. / Today the deliberate increase in the chances of death, / The conscious acceptance of guilt in the necessary murder" (Spain) $)^{\mathrm{xii}}$.

"Sumamente edificadores”, observa Orwell sobre los versos de Auden. "Repárese sin embargo en la expresión necessary murder (asesinato necesario); esto sólo lo podía escribir alguien para quien el asesinato es a lo más una palabra. Personalmente no hablaría en forma tan descuidada sobre el asesinato. Yo vi los cadáveres de muchos hombres asesinados ... Hitler y Stalin defendían al asesinato como algo necesario. No destacaban su brutalidad ni la definían como asesinato, sino como liquidación, eliminación o algo parecido. La amoralidad del cuño de Auden sólo es posible para alguien que no está ahí cuando se aprieta el gatillo” (Orwell, “En el Vientre de la Ballena”).

Sin embargo W. H. Auden era de una moralidad íntegra y como poeta tenía mucho talento para perseverar en su radicalismo verbal. Que morir y muerte no eran conceptos vacíos lo demuestra el siguiente poema escrito después de una visita al Museo de Artes de Bruselas. Si George Orwell lo hubiera conocido, difícilmente se habría abstenido de aclamarlo:

About suffering they were never wrong, The Old Masters; how well they understood The human position; how it takes place While someone else is eating or opening a window or just walking dully along (...)

xii “Mañana para los jóvenes, los poetas estallando como bombas, / Mañana las carreras de bicicleta / A través de los suburbios en tardes veraniegas. Pero hoy la lucha. / Hoy el aumento deliberado de la probabilidad de la muerte, / La aceptación consciente de la culpa en el asesinato necesario”. (Trad. de R. L.) 
In Breughel's Icarus for instance: how everything turns away

Quite leisurely from the disaster... (W. H. Auden Musée de Beaux Arts) $)^{\text {xiii }}$

A fines de 1936, George Orwell visitó a Henry Miller en París. Su novela Trópico de Cáncer, publicada el año anterior, le había entusiasmado. Orwell se dirigía a España para luchar en la guerra civil y defender la República atacada por las tropas de Franco. Como muchos intelectuales de izquierda, deseaba que sus palabras estuviesen respaldadas por sus actos y “matar con sus manos a un fascista”, como explicó delante de Henry Miller, cuya reacción fue un shock para Orwell: “Lo que más me sorprendió fue descubrir que él (Henry Miller) no sentía el más mínimo interés por la guerra civil. Me aseveró que sólo un idiota podría ir a España en ese momento. Podía comprender que alguien fuese por razones puramente egoístas — por ejemplo, la curiosidad-, pero inmiscuirse en semejantes cosas por sentirse moralmente obligado era pura idiotez. Mis ideas sobre el combate contra el fascismo y la defensa de la democracia no eran sino una estupidez" (Orwell, “En el Vientre de la Ballena”).

El proyecto de Orwell de matar a un fascista, fracasó. En la guerra de trincheras frente a la ciudad de Huesca, tomada por las tropas de Franco, divisó por fin a un soldado enemigo en el momento preciso en que éste se estaba bajando los pantalones. Orwell no pudo echársele encima y derribarlo, porque el hombre que satisface una necesidad natural no es un fascista sino un hombre común y corriente. Dos semanas más tarde, mientras Orwell asomaba la cabeza por encima del borde de la trinchera, una bala de escopeta le impactó el cuello. "The bullet went clean through my neck but missed everything except one vocal cord. I am rather glad to have been hit by a bullet. (...) What I saw in Spain did not make me cynical but it does make me think that the future is pretty grim” (Orwell, “Letter to Rayner Heppenstall”) xiv.

xiii “Acerca del sufrimiento ellos nunca se equivocaron,

Los antiguos maestros; cuan bien comprendieron

La situación humana; cómo tiene lugar

Mientras alguien come o abre la ventana o camina sin ánimo por ahí (...)

En el Ícaro de Breughel por ejemplo: como todo se aparta

Completamente sereno del desastre...”. (N. del T.)

xiv "La bala atravesó mi cuello limpiamente, no dañó nada, salvo una cuerda vocal. Estoy bastante contento de haber sido impactado por una bala. (...) Lo que viví en España no me transformó en un cínico, pero me hace pensar que el futuro es bastante lúgubre”. (N. del T.) 
En esa carta escrita poco después de abandonar España, Orwell le da indirectamente la razón a su antípoda Henry Miller. Lo que más le desilusionó no fue la bala que por un pelo no lo mata, sino que al salir del hospital militar de Barcelona, donde la policía secreta estalinista acosaba a trotzkistas y anarquistas, mientras el ejército de Franco estrechaba más y más el cerco alrededor de la ciudad, Orwell, recién sanado de su herida, debió sumergirse en la clandestinidad para escapar de sus perseguidores, puesto que como miembro de la milicia de extrema izquierda del POUM ${ }^{2}$ figuraba en la lista negra del NKWD ${ }^{3}$. Él y sus compañeros de lucha no sólo estaban amenazados de muerte por los adversarios fascistas de la República Española, sino que por los comunistas — una esquizofrenia imposible de explicarle a un bolchevista de salón en Inglaterra.

La simultaneidad del terror y de la normalidad es mucho más antigua que la literatura moderna. Aquello que Walter Benjamin define como choc $^{\mathrm{xv}}$ surrealista y Bertolt Brecht como efecto de distanciamiento, fue una práctica corriente en el arte en la Edad Media tardía y en los inicios del Renacimiento, sin hablar del Manierismo ni del Barroco. Piénsese tan sólo en Breughel o Jerónimo Bosch, aludido por Auden. Con frecuencia vivencié escenas semejantes en territorios en guerra o en crisis: mientras una bomba estallaba en la plaza del mercado de Sarajevo, despedazando a una mujer con sus hijos que esperaban por agua en una fila, en el "Café Europa” se servían capuchinos; mientras el ejército de tutsis de Ruanda masacraba a miles de hutus en los campos de refugiados Kibého, al borde de la piscina del hotel Mille Collines, un alto parlante llamaba a los clientes a almorzar; y mientras en el Sniper Alley de Sarajevo los transeúntes eran baleados como conejos, algunas calles más allá, la vida seguía su curso normal, “como si nada hubiese pasado”, como dicen las novelas por encargo.

La simultaneidad de estos procesos es más espantosa que los muertos y que los borboteos de sangre que aparecen a diario en los noticieros de televisión y que satisfacen el voyeurismo de los medios; mientras más cerca se está del suceso, mayor es la distancia con el espectador: un movimiento contradictorio que tiene efectos retroactivos en la percepción de la realidad. Yo me siento como en "una película de guerra”, me dijo un soldado de la Bundeswehr al descender del tanque en Prizren, rodeado de niños

${ }^{2}$ POUM (Partido Obrero de Unificación Marxista), partido de extrema izquierda en la Guerra Civil española que fue acusado de "trotzkismo” por el Partido Comunista supeditado a Moscú. Muchos miembros del POUM fueron asesinados.

${ }^{3}$ NKWD (Comisariado Popular del Interior), policía secreta estalinista. Organización sucesora de la GPU y antecesora del KGB.

${ }^{\mathrm{xv}}$ Choc en el original del francés (N. del T.). 
alegres que agitaban banderitas de papel de color negro-rojo-dorado y que gritaban "Thank you Deutschland”. “Esto de aquí es absolutamente irreal!”. A pesar de que, como la mayoría de los soldados, no simpatizaba con los clichés patrióticos de los medios y no confiaba en esa paz.

Yo tampoco confío en esa paz. Como una piedra que asoma de la tierra y cuya parte inferior está llena de gusanos y escarabajos, la guerra saca a luz una cruel verdad escondida detrás de la fachada luminosa de la cultura: la regresión a la barbarie es posible en todas partes y en todos los tiempos. Con una cesantía superior al treinta por ciento, la democracia parlamentaria se transforma en una ilusión sangrienta. Bullets statt ballots (balas en lugar de escrutinios): la opinión pública no se orienta ni por el partido más fuerte ni por el mejor argumento. La victoria la consigue el más brutal y mejor armado. El gobierno cede su dominio de la calle a los lores de la guerra o a los demagogos populistas — con frecuencia reunidos en una misma persona-, cuyos adeptos recluta en los bajos fondos del proletariado lumpen o en medio de adolescentes armados que fueron raptados después de que asesinaron a sus padres. Grupos marginales como neonazis y skinheads ganan terreno en el centro de la sociedad, mientras la guerra se vuelve el empleo más importante y, con frecuencia, el único que existe. El ejemplo de la juventud hitleriana movilizada en los últimos días de la guerra hizo escuela; los niños le dan menos significado al peligro y pueden ser adiestrados para matar con mayor facilidad que los adultos. Al igual que el Khmer Rojo en Camboya, la milicia Interahamwe, responsable del genocidio en Ruanda, y sus adversarios, el Frente de Liberación tutsi, estaban integrados por jóvenes y niños menores que no sabían leer, escribir ni contar, pero habían aprendido a manejar armas y explosivos; esto vale tanto para los "combatientes de la fe", argelinos y chechenos, como para los rebeldes de Sierra Leona y Liberia.

Los restos del ejército regular, parapetado en el Barclay Training Center de Monrovia, no tenían ninguna posibilidad contra los niños soldados, superiores en número, del FNPL (Frente Nacional Patriótico de Liberia) - este nombre por sí solo es pura ironía - de Charles Taylor. Ellos no entendían nada sobre tácticas y estrategias militares, corrían sin protección bajo el fuego de las ametralladoras. En mi primer recorrido por Monrovia, devastada por la guerra de tropas, apenas reconocí la ciudad que había visitado un año antes. Experimenté la sensación de un déjà vu. Las calles estaban rodeadas de cadáveres descompuestos, desgarrados por buitres y perros, mensaje en una lengua codificada cuyo sentido recién comprendí más tarde. Cada mañana —mientras los jóvenes combatientes aún dor- 
mían- saludábamos a los muertos como a viejos conocidos que habían cambiado un poco su aspecto durante la noche; para qué hablar del hedor. Aunque se arriesgaba la vida al cruzar una carretera, al aproximarse los periodistas, los combatientes suspendían el fuego y gritaban a los que estaban atrincherados detrás de los restos de automóviles la orden de dejar pasar a los extranjeros. Todos los bandos de la guerra civil respetaban esta convención, fenómeno que sólo me explico por la fascinación que ejercían los medios. Los adolescentes, aguzados por videos con imágenes violentas, deseaban ardientemente aparecer ellos mismos en pantalla y posaban a lo Rambo delante del equipo de televisión. En Monrovia, una vida humana no valía más de cinco dólares, y los jóvenes armados, en lenguaje popular freedom-killers (asesinos por la libertad), estaban dispuestos a ejecutar a un rehén delante de una cámara en rodaje por menos dinero.

La hora de la verdad llegó cuando Corinne Dufka, fotógrafa de la agencia Reuters, procedente de Nairobi, fue testigo casual de cómo los soldados de la FNPL maltrataron a un presunto miembro de la milicia $\mathrm{Khran}^{4}$, xvi. Desnudaron al hombre y comenzaron a hacer ademanes de castrarlo con un machete, por sadismo o, más plausiblemente, para impresionar a la mujer reportera. Después de haber fotografiado la escena, Corinne Dufka compró la libertad del prisionero y convenció a los torturadores de que lo dejaran ileso. Ella estaba orgullosa de haberle salvado la vida a un ser humano. A la mañana siguiente, el hombre yacía acribillado a la entrada del hotel.

Cuando le pregunté a un muchacho de unos dieciséis años, que se hacía llamar "Field-Marshall Rommel” (Mariscal de campo Rommel), por qué mataba a sus hermanos y hermanas africanas, respondió encogiéndose de hombros: "Why not?” (¿Y por qué no?) Un año antes, en mi primera visita a Monrovia, mi guía de entonces, Molly, me respondió así a la misma pregunta: "Ellos no necesitan un motivo para matarte". Me recordó un reportaje sobre una pequeña ciudad del medio oeste de Estados Unidos, que había leído años atrás en el New York Times: estudiantes de la escuela secundaria local, que se declaraban simpatizantes de una secta satánica, habían matado a golpes, con bates de béisbol, al más pequeño y débil de su grupo. Cuando se les preguntó por qué lo habían asesinado, respondieron riéndose: "Because it’s fun!” (¡Porque es divertido!).

\footnotetext{
${ }^{4}$ Milicia Krahn, partidarios militantes del presidente liberiano Samuel Doe, asesinado en 1990, que ocupó las posiciones claves con miembros de su etnia Krahn.

${ }^{x v i}$ Krahn es una de las etnias del interior selvático que desde la independencia han rendido servidumbre a las elites américo-liberianas de la costa (N. del T.).
} 
Nunca he sentido fascinación estética por la guerra, pero sí el vértigo de la violencia y la atracción del mal. Durante mucho tiempo consideré que esa atracción era una mentira piadosa bajo la que se escondían dudosos apóstoles de la moral. Hoy creo que el mal existe y he sentido en mi propio cuerpo cuán contagioso puede llegar a ser. Quien lucha contra dragones se convierte a su vez en dragón, escribe Nietzsche. Los horrores que presencié en mis viajes por territorios en crisis me han ido embotando; paulatinamente me he vuelto más insensible ante el sufrimiento de las víctimas o, peor aún, me he sorprendido gozando del espectáculo obsceno de la humillación pública de un ser humano. Fue en el otoño de 1996, en Grozny, donde los boieviki (así llamaban en ruso a los combatientes musulmanes de la fe que se decían a sí mismos mudjahidines) habían introducido la ley musulmana, la charia. Para amedrentar a los que pensaban de otro modo y robustecer la disciplina y la moral socavadas por la guerra, se decretó que las mujeres adúlteras debían ser lapidadas y a los ladrones se les cortarían las manos. Al mismo tiempo, el debate en torno a la charia era la expresión de una lucha de poder entre los fundamentalistas musulmanes y los partidarios del presidente Maskhadov, que pasaba por moderado. Las dos agrupaciones coincidían sólo en su odio contra el ejército ruso, el que por medio de sus bombas quería hacer regresar a Chechenia a la Edad de Piedra. Ese día habían anunciado la flagelación pública de un alcohólico, suceso de alto valor simbólico ya que los chechenos también apreciaban el vodka y se identificaban con las tropas de ocupación, cuya soldadesca cometía los peores excesos en estado de ebriedad. No quiero describir el vergonzoso ejercicio que se produjo en la plaza, delante de la oficina de la Comandancia, en presencia de la prensa internacional: el sentimiento de culpabilidad que sentí al contemplarlo, se intensificó con la irritación que invadió a la multitud de reporteros y periodistas.

La tragedia tuvo un epílogo jocoso: durante la noche desperté por un ruido sospechoso, vi a dos hombres armados que intentaban adueñarse de mi equipaje, pensé en un asalto o en un secuestro -la toma de rehenes de periodistas de Occidente estaban a la orden del día y nadie sabía si detrás de eso estaba la mafia rusa, chechena o el KGB. Pero los boieviki tenían otra intención: buscaban alcohol. Cuando lo encontraron, brindaron amablemente por mí y, sentados en la cama, se bebieron toda mi botella de whisky; después cargaron sus fusiles y desaparecieron silenciosamente en la oscuridad, tal como habían llegado.

“JÄGERMEISTER — EUROPE’S MOST POPULAR LIQUOR” (Jägermeister, el licor más popular de Europa) se lee en la camiseta del alcalde que 
combate a los insurgentes y que al mismo tiempo trabaja de guardia de la Rutile Mining Company sudafricana. Actualmente organiza la autodefensa de la población local. Su nombre es Alfred Bangali, tiene 43 años y es padre de doce hijos, de los cuales cuatro murieron durante la guerra civil en Sierra Leona. Por todas partes hay cabañas desmoronadas con sus techos de paja quemados; no sólo las casas, también los troncos están perforados por los impactos; una esquirla de granada que resiste fácilmente una palmera, puede ser mortal para un ser humano.

"Nyandehun Village, Imperi Chiefdom, Bonthe District, Mende people", con estas palabras nos presenta el alcalde a sus guerreros, hombres jóvenes, armados con machetes, lanzas y bayonetas, cuyos torsos desnudos están pintados de blanco y adornados con collares de huesos de animales y conchas de cauris, fetiches que los harán invulnerables. Uno de los combatientes porta una Kalachnikov y para intimidar al enemigo lleva los cartuchos en su boca. Los kamajors — así se llama la liga de hombres iniciados en la magia de la caza y la guerra — se parecen a los aborígenes de una película de Tarzán. Pero el juego es serio: están empapados de sudor por haber arrastrado corriendo, como a un ternero reacio, a un prisionero atado con cuerdas, presumible espía del ejército de los insurgentes capturado por sorpresa en un campo de maíz colindante. El prisionero tiene quince o dieciséis años; sangra de una herida en el brazo y tiembla de miedo mientras sus guardianes le ponen machetes y bayonetas en la garganta y le hunden el cañón de la Kalachnikov en el vientre. Lo acusan de haberse hecho pasar por un kamajor y de haber robado dinero de una cabaña —mil leones, que corresponde a más o menos un dólar, dice Alfred Bangali. No tengo tiempo de preguntarme si la historia es verdadera o inventada para impresionar a los visitantes blancos. El alcalde pregunta a los presentes qué se debe hacer con el espía, todos están de acuerdo con su ejecución. Y como prueba, con la punta de los machetes y bayonetas, tajan su pecho, del que brotan oscuras gotas de sangre. Le ruego al alcalde que perdone la vida del prisionero, pero la representante de una organización caritativa que me acompaña tiene otro parecer: la administración de justicia es patrimonio de las autoridades locales; yo no tenía derecho, según ella, de inmiscuirme en los asuntos internos de un pueblo africano. "El ladrón tiene suerte", responde Alfred Bangali, "sin su intervención, ahora sería un hombre muerto”.

Lo que más me espantó no fue la brutalidad de los kamajors sino mi propia reacción, sentí una emoción extática que recrudeció hasta el placer sádico cuando la sangre del joven comenzó a fluir. No; la memoria engaña, fue el espectáculo del esbirro armado que lamió con su lengua una gota de sangre desde la punta de su bayoneta — detalle obsceno que se me grabó 
con ácido indeleble en mi memoria. La cara del hombre estaba desfigurada por la voracidad y el odio, como la de un vasallo de guerra en un retablo medieval, mientras el torso desnudo del prisionero evocaba la imagen del San Sebastián de Botticelli, cuyo cuerpo traspasado por flechas emite señales eróticas. Mientras luchaba para salvar su vida, habría preferido participar en la tortura del joven. En un instante de descontrol, la barbarie traspasó el delgado barniz de la civilización.

“Nunca más debe desatarse una guerra en suelo alemán”. Este conjuro ritual fue considerado por décadas la conclusión lógica de la guerra comenzada y perdida por Alemania: esto unió a adversarios ideológicos como Erich Honecker y Helmut Kohl, y conformó la base del "cambio para el acercamiento" en el marco de la política de distensión auspiciada por las potencias aliadas. La reunificación pacífica de Alemania y el fin de la confrontación de bloques en Europa dio posteriormente la razón a la frase citada más arriba. ¿Pero si la guerra no se desata en suelo alemán, sino en suelo yugoslavo? Para este caso imprevisto, la frase no entrega indicación sobre cómo actuar. En el "nuevo orden mundial” que George Bush padre anunció al término de la Guerra Fría, no había lugar para conflictos armados, menos aún en Europa, donde se creyó que se habían aprendido las lecciones de la historia. La guerra era absolutamente lo otro; se había convertido en lo inconcebible: un estallido de violencia atávica que hacía añicos de manera sangrienta el sueño evocado en el discurso oficial de una sociedad civil y multicultural. Como no puede ser lo que no debe ser, hubo resistencia a aceptar el conocimiento de la espantosa realidad; se prefirió meter la cabeza bajo tierra. El que infringió la prohibición de pensar — siguiendo la frase de Clausewitz, según la cual, la brutalidad de la guerra no es razón para no considerarla - y exigió una intervención militar a fin de impedir una masacre de civiles, fue acusado por los apóstoles autoproclamados de la paz como instigador de la guerra y puesto en la picota.

No quiero imputar motivos de mala fe a los críticos ni desempolvar una vez más los debates a favor o en contra de las intervenciones de la OTAN en Bosnia y posteriormente en Kosovo. Más que el ritualizado intercambio de golpes, donde los argumentos de ambos bandos son previsibles, me irrita la posición de aquellos sabelotodo que reducen una compleja amalgama de tradiciones históricas y conflictos políticos sociales a una causa única y mayoritariamente económica: comercio de armas, diamantes o petróleo. Como si uno pudiese impedir una guerra cerrando la llave del dinero y cortando las actividades de los aprovechadores, ¡eso sería muy fácil! Esas tentativas de explicación son tan ciertas como falsas, peor aún: son banales. 
Esto no quiere decir que el lucro tenga una importancia secundaria, pero constituye sólo un estrato en la compleja amalgama de intereses. Más interesante que esta teoría marxista desgastada, de una conjura económica, es la idea de un fenómeno de deslumbramiento contagioso, que como una espesura de manglares sólo puede esclarecerse con un trabajo duro y meticuloso. Así, un seguidor tardío de la teoría crítica me explicaba que en la guerra de los Balcanes y el Cáucaso la lucha se libraba entre los perdedores de la modernización, que entre los escombros del socialismo de Estado se mataban entre sí con arpones y hachazos, como los náufragos en la balsa de la Medusa. Él me calificó como representante de la “falsa inmediatez" porque tomaba por cierto todo lo que veía, entendía y sentía, en lugar de descubrir las leyes ocultas que determinan los sucesos. Actualmente, el neo-hegelianismo es la forma más avanzada de una teoría de la conspiración y redención del mundo que descansa sobre la idea fija de que detrás de todo y de cada cosa se esconde siempre algo muy diferente y, por cierto, negativo y desagradable. "Precisamente el carácter repulsivo de una explicación te puede llevar a aceptarla”, señala Ludwig Wittgenstein en sus Vorlesungen über Ästhetik (Lecciones de Estética), tras lo cual se esconde una polémica con Sigmund Freud: “En especial, una explicación del tipo ‘esto es en realidad sólo eso’”. Y para probarlo, Wittgenstein agrega: “Muchas de estas explicaciones se aceptan porque tienen un atractivo particular. La idea de personas con pensamientos inconscientes es atrayente. La representación de un submundo, de un sótano secreto. Algo escondido, ominoso. Compárase con la historia de Gottfried Keller, en la que dos niños meten una mosca viva en la cabeza de una muñeca, luego entierran la muñeca y salen corriendo. (¿Por qué hacemos algo así? Porque así lo hacemos)”.

El ejemplo que Wittgenstein extrae de la novela de Gottfried Keller, Romeo und Julia auf dem Dorfe (Romeo y Julieta en el pueblo), coincide de manera sorprendente con un cuento de los hermanos Grimm que por su tranquilo tono narrativo deja de lado la moral, llevando al extremo la ausencia de toda ilusión. La distribución de roles entre víctima y victimario es aquí tan fortuita como el asesinato que se lleva a cabo, literalmente en un abrir y cerrar de ojos. Culpa e inocencia aparecen como las dos caras de una misma moneda, y el relato no depara un consuelo metafísico que haga soportable lo insoportable. El cuento confirma la deprimente conclusión de Wittgenstein: no son los otros, somos nosotros quienes hacemos algo así, sin saber por qué.

En una ciudad llamada Franecker, situada en la Frisia occidental, ocurrió que niños pequeños, de entre cinco y seis años, 
jugaban al barón y a la doncella. A un chiquillo le ordenaron ser el carnicero, al otro el cocinero y a un tercero, el puerco. (...) Según lo convenido, el carnicero se abalanzó sobre el niño que hacía las veces de puerco, lo derribó al suelo y le cortó la garganta con un cuchillito, la doncella recibió la sangre en un pequeño recipiente. Un concejal que pasaba casualmente vio la desgracia: tomó al carnicero y lo condujo a la casa del gobierno local donde reunió inmediatamente al Concejo. Deliberaron sobre el acto, pero no supieron cómo tomarlo, pues pudieron apreciar que había sido realizado con candidez infantil. (Wie Kinder Schlachtens miteinander gespielt haben) (Como los niños jugando al carnicero.)

Una bala vuela más rápido que el pensamiento; la reflexión siempre surge posteriormente, cuando es demasiado tarde. El conocimiento libresco no ayuda cuando se está confrontando la agonía y la muerte: el escritor Danilo Kiš, poco antes de morir, me confidenció que la única literatura que en su estado aún le interesaba, eran los reportajes médicos sobre su cáncer al pulmón. Hay un verso de Goethe que viene a mi mente cada vez que me encuentro ante víctimas de una masacre o de expulsión étnica: “Das Unbeschreibliche / hier ist's getan.” (Lo indescriptible / está aquí realizado). No hay nada más que decir, la lengua de la violencia reduce a todas las otras al mutismo; como es sabido, las musas callan ahí donde las armas comienzan a hablar. Y los dos versos que preceden la cita anterior, en el coro final de Fausto II, son un comentario adecuado a las impotentes tentativas de los observadores y miembros de organizaciones humanitarias que intentan limitar el daño y reparar la porcelana destrozada en las catástrofes: "Das Un-

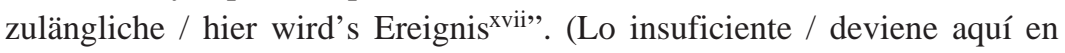
acontecimiento). Tal vez, entonces, la literatura pueda ayudar y no sea totalmente infructuosa frente al horror.

A propósito, no pienso tanto en la Campaña de Francia, obra de Goethe, con el clamor patético del poeta convertido en corresponsal de guerra: “¡Aquí y ahora se inicia una nueva época de la historia del mundo, y vosotros podréis decir que habéis participado en ella!” Aun cuando el informe que Goethe hace de su participación en la campaña militar contra la Francia revolucionaria agrada por estar exento de propaganda nacionalista, el poeta de Weimar expresó un pensamiento decisivo sobre la guerra y la paz en su Iphigenie auf Tauris (Ifigenia en Táuride), que tiene injustamente reputación de melodrama clásico, desligado de toda relación con la realidad.

xvii En Goethe, das Unzulängliche refiere a lo "imperfecto"o "insuficiente” y no a lo "inaccesible”. Cfr. Archipel de la Douleur, p. 348, nota de Nicole Casanova (N. del T.). 
"Sólo la felicidad de la mujer está encerrada en sus estrechos límites; ella constantemente agradece su bienestar a otros, con frecuencia extraños, y cuando su casa es destruida, el vencedor la conduce desde las ruinas humeantes a través de la sangre derramada de quienes ella ama y están muertos”, así se lee en el monólogo inicial, donde Ifigenia, con argumentos feministas, según el punto de vista actual, pone en tela de juicio el principio masculino de la realidad. El escenario en el que se desarrolla el drama, la isla Táuride, dominada por el rey bárbaro Thoas, se sitúa — supuestamente según la tradición - en la costa dálmata o en el Krim. El texto de Goethe también se puede leer como un comentario de la guerra en Kosovo o Chechenia. No sólo los escitas desprecian la ley de la hospitalidad y sacrifican extranjeros a sus dioses, los griegos también son bárbaros: desafiando sus discursos humanitarios, se libran a la piratería en costas lejanas, donde matan, violan y reducen a la esclavitud a sus habitantes. Lo mismo que en Chechenia o Kosovo, se confrontan dos principios excluyentes: la pretendida cultura superior y el referente ideal de humanidad de los griegos, que pisotean los derechos de otros pueblos, y la barbarie de los escitas, que efectúan sacrificios humanos y cuyo rey, como Winnetou, el cacique de los apaches, es un auténtico salvaje.

\footnotetext{
THOAs: No soy yo, es una antigua ley que ordena este sacrificio.

IFIGENIA: Otra ley, más antigua aún, me ordena resistir.

THOAs: ¡Tú sabes que hablas con un bárbaro y aún así confías que él percibirá la voz de la verdad!

IFIGENIA: La oye cada uno, en cada lugar bajo el cielo.
}

El drama de Goethe trata de un conflicto que es la base de todo proceso de civilización: el reemplazo del sacrificio humano y de la venganza - ojo por ojo, diente por diente- por el derecho codificado por los hombres. No es casualidad que Ifigenia — precisamente destinada a ser una víctima ella misma - convenza al rey bárbaro, que tiene rasgos de su padre, Agamenón, de renunciar a la violencia.

IFIGENIA: ¡Oh! ¡Tiéndeme la mano en son de paz!

THOAS: ¡Exiges demasiado en tan corto tiempo!

Ifigenia: Para hacer el bien, no se necesita reflexionar.

THOAs: Demasiado, a ver si del bien no surge el mal.

IfIGENIA: ¡No vaciles más! ¡Cede a tus sentimientos!

(Ifigenia en Táuride, versión en prosa de 1779) 
El sonido melodioso del lenguaje de Goethe no proviene de una ruptura con la realidad discordante, sino de la perseverancia de sus contradicciones; el poeta conquistó en su obra la belleza y la verdad en una época que no era menos dura que la nuestra. Y sólo aquel que lanza una mirada a su propio presente puede medir el prodigio estético realizado por el arte clásico.

\section{II}

¿Cuál es la verdadera realidad? ¿Nuevos combates en las afueras de Grozny entre rebeldes chechenos y unidades Spetsnats ${ }^{5}$ del ejército ruso; el bombardeo del aeropuerto de Asmara, la capital de Eritrea, por la fuerza aérea etíope; el acoplamiento de un nuevo módulo de la estación espacial Zvezda en la ionósfera, a 370 kilómetros sobre la tierra? ¿O lo que ocurre un día $x$ cualquiera? El director de la Reserva Federal de Estados Unidos, Alan Greenspan, desmiente los rumores de una próxima alza de las tasas de interés del dólar; Bill Clinton le hace saber a la prensa, reunida en la rosaleda de la Casa Blanca, su preocupación por la participación del populista de derecha, Haider, en el gobierno austriaco; el equipo nacional alemán de fútbol sale trotando de la cancha, derrotado; Pete Sampras tira su raqueta al aire y el piloto de la Fórmula 1, Michael Schumacher, riega a sus compañeros de equipo con una enorme botella de champaña. Las imágenes son intercambiables y corresponden a los noticieros, como el mapa meteorológico que permanece igual por más que las altas y bajas presiones cambien constantemente de nombre y lugar. Pero el carácter iterativo de los procesos engaña: mientras un módulo se acopla en alguna parte y los cosmonautas maniobran con destornilladores en el espacio, la tierra es bombardeada y ametrallada; en vez de ser el equipo nacional de fútbol el que deja la cancha, a veces es Pete Sampras quien sale de la cancha derrotado, o es el Ferrari de Schumacher el que se hace trizas escupiendo fuego y humo.

¿Cuál es la verdadera realidad y qué método de representación es el más adecuado? ¿La tragedia, cuyo final sangriento debe provocar en el espectador la esperada catarsis; la poesía lírica que compensa con el placer estético la miseria real existente; o la narración épica que reposa sobre la infinita variación de lo semejante? "Entre tanto la ciudad de Lisboa, en Portugal, fue destruida por un terremoto; la Guerra de los Siete Años pasó, el emperador Francisco I murió; la Orden de los Jesuitas fue suprimida;

${ }^{5}$ Unidades especiales rusas, análogas a las special forces del ejército de Estados Unidos. 
Polonia fue dividida; la emperatriz María Teresa murió; América se liberó, (...) la Revolución Francesa y la larga guerra comenzó; Napoleón conquistó Prusia, los ingleses bombardearon Copenhague; los labradores sembraron y segaron. El molinero molió, los soldadores martillaron y los mineros excavaron en busca de filones de metal en su taller subterráneo"6.

Este célebre texto de un escritor del área de habla alemánica [alemannisch] $]^{\text {xviii }}$, que no tenía nada de provinciano, marcó la irrupción de la política en la literatura. Su origen coincide con la introducción de aquello que hoy calificamos como mass-media. El Schatzkästlein des Rheinischen Hausfreundes (Cofrecillo de joyas del amigo de la casa renano) era asimismo una especie de diario que, bajo el título Vermischtes (Miscelánea), reunía en la misma página impresa enseñanza y pasatiempo, diversión y formación. La descuidada yuxtaposición de faits divers (hechos diversos) del macrocosmos y los microcosmos, de la historia y la naturaleza, de la patria y el vasto mundo, que había sido natural para Johann Peter Hebel, no lo sería para Adalbert Stifter cincuenta años más tarde. Stifter no sólo excluyó de su universo poético la política sino también, a causa de su incidencia en las revoluciones de 1848, las catástrofes naturales, las que se volvieron sospechosas para el poeta idílico cuya vida finalizó, de manera muy poco idílica, con el suicidio.

El soplo del aire, el murmullo del agua, el crecimiento del trigo, la ondulación del mar, el resplandor del cielo, el centelleo de las estrellas, esto considero grande. La tormenta que arrasa majestuosamente, el rayo que parte las casas en dos, la tempestad que impulsa el oleaje, la montaña que escupe fuego, el terremoto que sepulta comarcas enteras, son fenómenos que no me parecen más grandes que los evocados anteriormente; por el contrario, parecen más pequeños porque únicamente son consecuencias de leyes superiores, se producen en forma aislada y como resultado de causas unilaterales.

El accionismo fanático que se expresa en el siguiente pasaje del Manifiesto del Futurismo, frecuentemente citado, se sitúa en un lugar diametralmente opuesto a la meditación budista zen de Adalbert Stifter. Verlo como una glorificación púber de la guerra que Marinetti sólo conocía de

${ }^{6}$ Johann Peter Hebel, Schatzkästlein des Rheinischen Hausgreunds (1811), colección de novelas, anécdotas y ensayos en forma de un almanaque. [Para la traducción al castellano se tuvo a la vista la versión de Alba Editorial: Cofrecillo de Joyas del Amigo de la Casa Renano (s.l., 1998).]

xviii Alemánico (Alemannisch) pertenece a la familia de las lenguas germánicas del alto alemán. Alrededor de diez millones de personas lo hablan en Alemania, Francia, Suiza, Italia y Liechtenstein. (N. del T.) 
segunda mano, es tomarlo demasiado a la ligera. En comparación con la batalla material de Verdún, la guerra colonial etíope, a la que se refiere el manifiesto, fue una escaramuza anodina. A pesar de, o más bien, a causa de su exaltación, se trata de un texto fundacional del siglo XX que relaciona la concepción arcaica de la guerra como madre de todas las cosas, con la embriaguez de la velocidad y el pathos por la técnica moderna:

¿Para qué miramos hacia atrás, ahora que derribamos los portones misteriosos de lo imposible? Nosotros ya vivimos en lo absoluto, puesto que hemos creado la eterna velocidad omnipresente. Queremos glorificar la guerra — esta única higiene de mundo-, el militarismo, el patriotismo, el gesto destructor de los anarquistas, los bellos pensamientos que matan...

Sobre mi escritorio hay un cartucho de 13,5 milímetros, no se trata del proyectil de una Kalachnicov, que se encuentra masivamente en todos los escenarios - iqué palabra! — de las guerras civiles del mundo (la AK 47 ha matado a más personas que la bomba atómica y su galardonado inventor aún vive en un asilo de ancianos en Rusia), pues no es el cartucho de una Kalachnicov sino de una ametralladora. La bala de plomo, inserta en el casquillo plateado en forma de cohete escalonado, todavía está intacta y apta para matar. Esta afirmación es parcialmente cierta pues la punta del proyectil es cónica, no tiene forma de bala y no está hecha de plomo sino de acero recubierto con una aleación de cobre. Lo mismo que el emblema de Córcega, una cabeza adornada con una cinta que hace recordar a quien la mira sus últimas vacaciones en la isla, este cartucho me evoca el sitio donde la recogí. No sé bien si fue en el verano de 1995 en Mostar o en la Neretva donde musulmanes bosnios y croatas, del llamado ejército patrio, se ametrallaron unos a otros durante meses. No solamente las casas de la antigua ciudad musulmana, distinguidas por la insignia con azul y blanco como patrimonio cultural de la humanidad, sino también los postes de los faroles del antiguo paseo de la ribera estaban perforados por los impactos - troquelados sería una palabra más precisa. ¿O fue en la Plaza Minutka, en el antiguo centro de la ciudad de Grozny, donde soldados del OMON ${ }^{7}$, provenientes de la lejana Siberia, se inmortalizaron por medio de obscenos graffitis que dibujaron en el palacio destruido donde el presidente Dudajev había gobernado Chechenia? Imágenes sacadas de un filme de Eisenstein: lámparas colgantes tumbadas en el piso, cajas de municiones vacías, el esqueleto de un caballo; gran Avenida Lenin, calle de la Paz, ornamentada con las

${ }^{7}$ Tropas especiales del ministerio del Interior moscovita. 
ruinas calcinadas, cavidades sin ventanas, el agua goteando de los radiadores de calefacción, pasaje subterráneo minado, restos de carrocería de un tanque. Aquí, el convoy del comandante ruso de la ciudad fue dinamitado en el aire y unos metros más allá el ejército ruso abatió "por equivocación" a una reportera americana. No recuerdo bien dónde recogí este cartucho, pero cuando cierro los ojos, veo una flor que crece en todos los escenarios de guerra, azul como un aciano o tal vez una margarita ligeramente sombreada con tinta por un calígrafo del Lejano Oriente; sin embargo se trata de un diseño que dejó sobre el asfalto la explosión de una granada al impactar el suelo y lanzar esquirlas en todas direcciones: no se trata de un profundo cráter ni de un embudo rajado por la cavidad de una bomba, es una composición abstracta dibujada por finas rayas, rasguños y escarificaciones minuciosas, como un minimalismo estético. Como la magdalena que Proust sumerge en su taza de té, la flor grabada en el asfalto despierta en mí un mundo sepultado, aparentemente más real que la llamada cotidianeidad normal que me rodea. Esto no quiere decir que yo busque una infancia perdida, aunque haya crecido, al igual que la mayoría de los autores alemanes de mi generación, en ciudades destruidas por las bombas: nací en 1944 —un crimen de guerra imprescriptible. Pero las heridas que el combate final de la toma de Berlín infligió en calles y casas, y que hasta hoy no han cicatrizado, se ven diferentes a las "flores de asfalto" en los territorios en crisis y en guerra del tercer mundo. Que la guerra total desatada por Hitler haya cubierto zonas más extensas y haya sido más mortífera que las guerras civiles moleculares de los años 90 es un nimio consuelo para sus víctimas. Así como la referencia al genocidio perpetrado por los nazis sobre el pueblo judío no hace inofensivos otros crímenes contra la humanidad.

Para mí no se trata de fascinación estética. Por el contrario, las imágenes de la destrucción son monótonas y aburridas, "codificadas por un mutismo atroz", como escribía Franz Marc en sus Briefe aus dem Felde (Cartas desde el frente), aunque cada bomba deje un cráter diferente que la otra. El espanto inicial cede lugar rápidamente a la rutina, más terrible aún, porque muestra la rapidez con que uno se acostumbra a lo insoportable. Para mí tampoco se trata de un sentimiento de déjà-vu que vuelve a surgir cada vez que me aproximo a una zona de combate y saludo las huellas de la violencia como antiguas conocidas que no veía hace mucho tiempo: una cocina o un refrigerador en un pastizal, un sofá cuyos cojines y borlas son arrasados por la corriente de un arroyo en la montaña — escenas de la guerra de los Balcanes a la que también corresponden los ladridos de los perros que después del desalojo de sus amos vuelven a reunirse en jaurías, o los 
caballos que pastan las uvas de una viña. De un auto en movimiento no se puede distinguir si se trata de ladrones o desalojados que intentan salvar sus bienes, ya que saqueadores y habitantes en fuga son difíciles de distinguir a simple vista, incluso en Liberia o Timor Oriental, cuando portan tejas de chapa ondulada enrolladas sobre su cabeza. La realidad se transformó en algo funcional; la vista que nunca engaña ya no dice nada más sobre los sucesos concretos, pues la pregunta decisiva acerca de si alguien es víctima o victimario, hutu o tutsi, timoriano o indonés, es tabú en la mayoría de los territorios en guerra. Para los involucrados todo está claro, la curiosidad del reportero es tan absurda como si en un campo de concentración se le preguntara a un hombre con pijama de rayas si es un detenido o un guardia.

Zapatos de mujeres y niños, fotografías de familia y papeles de identidad en la vereda de las calles exacerban el horror, pues ningún fugitivo se separa voluntariamente de su pasaporte o cédula de identidad. Cuando uno se topa con estos vestigios, no se halla lejos de la fosa común, que se nota por la tierra fresca y recién excavada de la que emana un hedor dulceamargo a putrefacción. Pero la desaparición de las huellas de los crímenes, la sepultura, el entierro provisorio de los muertos son excepciones. Generalmente éstos yacen sin sepultura porque la retirada precipitada no dejó tiempo, o porque la exposición de los cadáveres cruelmente mutilados sirve para espantar al adversario e intimidar a la población civil, como es habitual en Haití, Liberia y Sierra Leona, tres Estados fundados por los esclavos liberados y donde el legado de la esclavitud produce aún sus efectos. "Pregúntele a aquel vendedor de carne humana, qué es la propiedad. Él dirá, mostrando el largo ataúd al que llama nave, dónde encajonó y hacinó a los hombres que llama vivos: he aquí mi propiedad; yo pagué tanto por cada unoxix". Yo vi esa nave en Monrovia a un costado del cementerio, donde el último presidente civil, Tolbert, fue enterrado vivo después de haber sido descuartizado en su cama con su mujer y sus hijos; su sucesor, el suboficial Samuel Doe, fue asimismo víctima de la guerra civil desatada por su soldadesca bajo un pretexto insignificante. Un lord de la guerra llamado Prince Johnson lo torturó a muerte delante de las cámaras. El cassette de video que muestra la tortura del jefe golpista fue un bestseller en Monrovia. Lo que se parece a una nave varada de esclavos es la prisión del Estado de Liberia: un bloque de concreto con estrechos tragaluces en lugar de ventanas, recalentado

xix Robespierre, Discurso sobre la Propiedad, 24 de abril de 1793. Comentario hecho al proyecto de Declaración de Derechos que él propuso a la Convención. Véase Jean Massin, Robespierre (Paris: Alinéa, 1988), p. 168 s. Cfr. H. C. Buch, Archipel de la Douleur, p. 349 s. (N. del T.). 
como una sauna por el sol del trópico. Del interior oscuro de la galera de presidiarios se escucha el rechinar de las cadenas y el canto rítmico de los presos que protestan porque los dejan morir de hambre y se pudren vivos. A mi pregunta acerca de dónde quedó el dinero donado por las organizaciones humanitarias para la alimentación de los presos, el director de la prisión me responde: "¡Liberia es un país libre, pero si usted sigue haciendo preguntas indecentes, lo voy a tomar preso!"

La guerra invierte el interior hacia el exterior: esta metáfora es literal en un cruce de Monrovia donde una cabeza cortada reemplaza al semáforo para indicarles a los automovilistas: hasta aquí y no más allá. Al mirar de cerca reconozco que la cuerda tendida a través de la calle, bloqueando el acceso al puente, es el intestino de un asesinado cuyo cuerpo decapitado está sentado en una silla de oficina. La expresión naturaleza muerta es aquí doblemente propicia: el asesinado tiene en su vientre una cornucopia con frutas que parecen uvas manando del borde de una copa, como en las pinturas holandesas; el jugo fermentado atrae a las moscas irisadas. Gottfried Benn habría escrito aquí uno de sus poemas sobre la morgue, pero las fotografías de prensa son más discretas que el espantajo burgués expresionista: ellas capturan la escena y apartan la vista simultáneamente. Con frecuencia constaté esta paradoja de mirar y, al mismo tiempo, apartar la vista, de los horrores de la guerra. En la morgue de Nairobi, el corresponsal para África oriental del New York Times sostenía su sombrero delante de la cara para no ver de tan cerca a las víctimas del atentado contra la embajada norteamericana, para no tener que inhalar el hedor: impotente reacción de rechazo, basta un fragmento de segundos y la horrorosa imagen queda para siempre marcada a fuego rojo en la memoria — esto se llama quedar traumatizado. Después, el reportero se puso verde y vomitó, aunque había visto peores cosas en otras partes. Lo peor no eran las entrañas arrancadas por la presión de la explosión que el muerto sostenía como un paquete en su regazo, o la cabeza de la mujer reducida a una masa de puré: mucho más consternante era la coexistencia apacible del espanto y de la normalidad: los zapatos marrones del hombre y los pantalones Levi's de la joven mujer que pocas horas antes, cuando aún tenía un rostro, había sido rubia y bella.

"El sufrimiento de esta sola criatura me roe el tuétano del hueso (...) y tú, ríes sarcástico y tranquilo sobre el destino de miles de otros”, dice Fausto a Mefistófeles, antes de entrar al calabozo donde Margarita espera al verdugo. Y Mefistófeles le responde:

¿Por qué andas en nuestra compañía, si tú no puedes soportar las consecuencias? ¿Es que nosotros te hemos invocado o es lo contrario? 
(...)

FAUSTO: ¡Sálvala! ¡... Oh, ay de ti!

MefistófELEs: ‘¿Sálvala!’ —¿Quién era el que quería su perdición? ¿Yo o tú?

Fausto mira conternado en torno suyo.

La sensación de déjà vu que me invade ante escenas de este tipo no se refiere a una experiencia precisa que he suprimido de mi conciencia en vigilia, sino al olvido en general; no al olvido de alguna cosa, sino de cosa alguna, como se decía antes, cuando se usaba el verbo conmemorativo —al pensar en o recordar a - aún con el genitivo objeto: I forgot to remember to forget. No se trata de una pena de amor como en la canción de Elvis Presley, que uno preferiría olvidar antes que conservar en la memoria. Se trata de algo fundamental: una dimensión de la existencia que es tan seria y profunda, que hace difícil si no imposible continuar viviendo, porque a partir de esta perspectiva todo lo que otros consideran normal aparece como ilusión sin consistencia: “FUI QUOD ESTIS, ERITIS QUOD SUM ${ }^{\mathrm{xx}}$,, se lee sobre el portal a la entrada del camposanto San Juan en Nuremberg, donde Albrecht Dürer fue sepultado. “Todo es vanidad”, dice el Eclesiastés, un conocimiento que se sobreentendía en sociedades premodernas y que se perdió más tarde, por más que en la Fenomenología de Hegel la vida del espíritu sea definida como "conservar y contener la muerte en sí”. Pero no soy promotor de una metafísica barata, una mixtura popular de existencialismo sartreano y ontología heideggeriana. Se trata de una experiencia empírica que debí hacer en los territorios en crisis o en guerra, porque en casa, el entorno habitual deforma la mirada: el desorden es más fuerte que el orden, que asimismo es una especie de desorden —entropía es otra palabra para aquello. El conocimiento de que en los sistemas inestables el caos es la única constante no está lejos de la idea de que bajo tales circunstancias el “worst case scenario" no es la excepción sino la regla. Desde este punto de vista, la idea de la "paz eterna” es una utopía totalitaria que sólo una dictadura mundial podría imponer, como Kant la demostró, y “el hombre nuevo”, que fue proclamado con bravuconería por fascistas y comunistas, se parece más a Frankenstein que al Apolón de Belvédère. Pero también el ideal modesto de "la educación para la paz" ha naufragado como lo demuestra el retorno de la guerra en la agenda política internacional después de la inflexión y transición histórica de 1989.

xx “Yo fui lo que usted es, usted será lo que yo soy”. Véase el soneto de Corneille a Marquisse. Cfr. H. C. Buch, Archipel de la Douleur, p. 350 (N. del T.). 
Hay heridas que son peores que la muerte. A un hombre joven, por ejemplo, en el campo de refugiados de Kibeho, le han volado la mandíbula inferior con un golpe de machete - no hace semanas, meses, años, sino pocos minutos antes de tenerlo frente a frente. Kibeho está situado al sur de Ruanda y el 22 de abril de 1995 se celebra el primer aniversario del genocidio que costó la vida a más de un millón de tutsis y hutus moderados que renunciaron a hacer causa común con los sangrientos asesinos. Ese día el ejército tutsi de Ruanda, que desterró a la milicia hutu del país, se vengó por el genocidio, no contra los uniformados que asesinaron a sus parientes, sino contra los refugiados civiles desarmados: hombres, mujeres y niños previamente hacinados en un lugar del porte de una cancha de fútbol, sometidos a disparos continuos, desconectados de cualquier tipo de suministros y expuestos a un sol ardiente y a una lluvia glacial. En ese momento, no me pude percatar que se trataba de un acto de venganza planificado, la comprensión llega siempre demasiado tarde, post festum, cuando lo acontecido no puede revertirse: "lo indescriptible, está aquí realizadoxxi”. El hombre joven ignora quién y por qué voló su mandíbula inferior; si fue un soldado tutsi o un miembro de la milicia extremista hutu que aterroriza a los refugiados en el campamento; él no lo sabe y si lo supiera, después de este corte que transformó su cara en una fuente que en lugar de agua mana sangre, no podría importarle menos. El herido emite un ruido gargarizante mientras un colaborador de Médicos sin Fronteras (MSF) desinfecta los bordes de la herida con micromina, un remedio casero que se utilizaba contra llagas y rasguños en mi periodo escolar francés a fines de los años 50. “Lo insuficiente, deviene aquí en acontecimientoxxii”. Ni en una clínica de urgencia equipada con tecnología moderna tendría este joven una mínima oportunidad de sobrevivir — pero ¿y en esta enfermería provisoria, rodeada de muertos y agonizantes, huérfanos que perdieron aquella mañana a sus padres y médicos al borde de una crisis nerviosa? En su lugar yo le pediría al soldado ucraniano de casco azul, apostado en la entrada de la enfermería, que me diera un disparo, pero las tropas de la ONU no tienen armas y los combatientes del ejército tutsi no complacerían su deseo. Con la misma argumentación, en la obra de Büchner el Collot d’Herbois niega la petición a una aristócrata condenada a ser ejecutada con prontitud: "Ciudadana, no hace mucho que deseabas la muerte”.

Intento apartar la mirada, pongo mi brazo en el hombro de la auxiliar de desarrollo argelina que al ver al herido vomita y casi se asfixia, pese a

\footnotetext{
xxi Aquí refiere a Goethe, Fausto II. Véase la sección I, supra (N. del T.).

xxii Ibid. Véase sección I, supra (N. del T.).
} 
que minutos antes había expresado su comprensión por la intervención masiva del ejército ruandés. Mi gesto de consuelo no está exento de atracción erótica: ¿la violencia como afrodisíaco? Más bien se trata de una tentativa de soportar lo insoportable, ya que mi deseo sexual pareciera ser la única cosa normal en este día. Poco antes había presenciado morir a una joven mujer con una herida abierta en el cuello — presumiblemente por un golpe de machete-, ingresada en la atención de urgencia, apartada del resto del campamento: su respiración intermitente se detuvo después de que una asistente de Médicos sin Fronteras le fijara el suero en el pliegue del codo. La muerta fue envuelta en una frazada y levantada por encima del alambrado. Soldados tutsi la lanzaron junto a los muertos del día en un camión que aguardaba con el motor encendido. De pronto la asistente quiere ver mi credencial de prensa: mi ingenua pregunta, quién dispara a quién, la hace desconfiar, 'aunque', o 'porque', ni ella misma puede responder a esa pregunta. La palabra masacre me viene a la mente y aun cuando intento percibir el horror sólo de reojo, para no dejar que las horribles imágenes de este día se impregnen en mi conciencia, éstas reaparecen semanas y meses después en mis pesadillas. Apenas cierro los ojos, escucho su respiración jadeante y agónica, veo su pecho desnudo, que se empina y desciende por última vez. ¿Violencia como afrodisíaco?

La relación entre sexualidad y violencia era casi palpable durante las luchas callejeras —matanzas sería más apropiado- en abril de 1996 en Monrovia. Cada mañana un jeep robado, con el emblema de la OMS (Organización Mundial de la Salud), atravesaba la frontera en el medio de la ciudad distribuyendo drogas estimulantes y videos de violencia y pornografía a los combatientes del FNPL (Frente Nacional Patriótico de Liberia), jóvenes armados que se denominaban a sí mismos freedom fighters, traducido en dialecto liberiano por freedom killers. Niños soldados del FNPL de Charles Taylor, adiestrados para matar como perros de riña. Tal vez eso explica por qué les tenían un máximo respeto a los camarógrafos mientras abrían fuego contra los reporteros que no traían cámaras consigo. Este fenómeno no sólo se observaba en África: los skinheads de extrema derecha que en los alrededores de Berlín "golpeaban a los fidschis" —así se le llama a la cacería de vietnamitas en la jerga neonazi-, posaban complacientes ante fotógrafos japoneses, no porque la Alemania de Hitler haya estado aliada con Japón durante la Segunda Guerra Mundial, sino por respeto a su imperturbable profesionalismo. "I like Neo-natshi”, me decía Sato, un reportero japonés que se hizo famoso en su país por sus fotos a neonazis, "German Neo-natshi very good story”. Sato caracterizaba de la siguiente manera la lucha por el poder en Haití, finalizada por una intervención militar interna- 
cional en otoño de 1994: "¡President number one fight president number two: bang, bang, bang!” Eso explica que sus documentales sobre el horror de la guerra en la antigua Yugoslavia se hayan vendido clandestinamente en videoclubes japoneses como pornografía, no por interés político en el conflicto de los Balcanes o por empatía con las víctimas, sino porque los espectadores se excitaban mirando las escenas de crueldad.

Más evidente aún se hace la relación entre sexo y violencia a partir de la siguiente historia, lamentablemente verdadera, que me contó un sobreviviente del genocidio perpetrado por el Khmer Rojo en Camboya. Sok Sinn, que actualmente trabaja para periodistas extranjeros como chofer y traductor, tenía 11 o 12 años cuando en abril de 1975 el ejército de partisanos de Pol Pot entró victoriosamente en Phnom Penh. Aunque no pertenecía a la clase de los privilegiados — su padre cayó en la guerra y su madre alimentaba a los hijos con la venta de helados-, fue arrancado de su familia y enviado desde la ciudad al campo, donde se convirtió en miembro de una chalat, o brigada de jóvenes. De la mañana a la noche debían cavar fosas, levantar diques y trabajar en arrozales inundados. La alimentación consistía en un ligero puré de arroz —el robo de un mango o un trozo de caña de azúcar era castigado con la pena de muerte-; después del trabajo había asambleas políticas donde los adolescentes ejercían su autocrítica, condenaban al imperialismo y agradecían a Angkar, el partido omnipotente, por sus beneficios. Por la noche los soldados dispuestos para la guardia se emborrachaban y recorrían la fila de los dormidos buscando mujeres jóvenes que violar. Los que se quedaban con las manos vacías, buscaban de manera arbitraria una víctima y la golpeaban con pico y pala hasta matarla - las balas eran demasiado preciadas para usarlas contra los enemigos del Khmer Rojo. Cuando le pregunté por qué lo hacían, Sok Sinn, que agradecía el hecho de haber tenido un ataque de diarrea en el momento de su condena, me miró sorprendido: "ellos siempre encontraban un motivo para matarte —así me dijo-, pero te mataban también sin motivo”.

Esa frase la había escuchado ya hace diez años, después de la masacre del día de las elecciones, el 29 de noviembre de 1987, cuando en el centro de Port-au-Prince, el ejército abrió fuego contra jóvenes desarmados que se hallaban en fila en el patio de una escuela esperando para hacer uso de su derecho a voto. Eran las primeras elecciones libres después de la dictadura de Duvalier; ya en la víspera había habido atentados de incendio, amenazas de muerte, y se temía irregularidades en el escrutinio o una manipulación de su resultado. Pero lo que entonces ocurrió, no lo hubiese imaginado ningún observador internacional llegado a Haití: de la plataforma de 
un camión militar, el ejército disparó a la población civil y asesinó a varias docenas de personas, en la mayoría jóvenes votantes. Media hora más tarde, mientras permanecía estupefacto en el patio de la escuela sembrado de cédulas electorales ensangrentadas, regresaron los soldados y masacraron con cuchillos y machetes a heridos y muertos, algunos de los cuales aún parecían jadear como en medio de un sueño agitado. Ante las cámaras que grababan, cargaron los cadáveres en el camión y partieron con rumbo desconocido dejando una estela de sangre tras de sí.

Dos días más tarde se efectuó una conferencia de prensa en el palacio presidencial de Port-au-Prince. "El ejército de Haití es una institución soberana”, dijo el jefe de la Junta Militar de Gobierno, general Namphy, contestando a una periodista judía de Nueva York, "y siempre puede matar, cuando y a quien quiera. Mientras se trate de ciudadanos haitianos, no necesitamos rendir cuentas al extranjero". Su representante, Prosper Avril, antiguo jefe de la guardia de palacio bajo Baby Doc, con gafas de sol siempre puestas, le susurró algo al oído. Namphy tragó saliva y se corrigió: "Lo que acabo de declarar no quiere decir que todo lo que hagan nuestros soldados proviene de una orden de arriba. Ni siquiera nosotros sabemos si fueron miembros del ejército los que participaron en el incidente de la ruelle Vaillant. En el caso que así fuera, entonces se trató de servicios subordinados que actuaron por propia iniciativa. Por supuesto que los responsables serán sancionados. Pero debemos esperar el resultado de la investigación”.

Desde la perspectiva de Namphy, estos dichos no parecían ser contradictorios. Pero su forma de pensar era tan primitiva que escapaba a la comprensión de los corresponsales de prensa: según la lógica del general, el pueblo era ingrato. El ejército había liberado a Haití de la esclavitud en 1791, 1804 y ahora de nuevo. El ejército se había sacrificado por el pueblo. En vez de agradecer a los militares, la gente se manifestaba en las calles y escribía en muros y paredes de las casas: “À BAS L’ARMÉE”. Y en vez de confiar en la dirección del ejército, seguían a los cazadores de ratas venidos del extranjero e iban a votar. Los soldados habían sancionado al pueblo por esta insubordinación. Todo esto era evidente, pero sobrepasaba el entendimiento limitado de una periodista de Nueva York que prefería difundir mentiras y calumnias sobre el ejército de Haití.

Hay heridas que son peores que la muerte. Por ejemplo, el muchacho de once años —llamémoslo Hassan- que me fue presentado en el centro de prensa de Argel por la organización Madres por la Paz, o tal vez se llamaba Madres contra la Guerra. La palabra "centro de prensa” es bastante inadecuada: se trata de la imprenta de los periódicos controlados por el 
Estado, El Watan y El Moudjahid —bajo el régimen militar de Argel no existe prensa independiente-, que después de los atentados con bombas perpetrados por fundamentalistas islámicos, se halla rigurosamente vigilada y para ingresar a ella se requiere autorización especial. En un primer momento pareciera estar ante una niña, ya que el muchacho porta un paño sobre su rostro, pero no es un velo, como prescriben los islamistas a sus mujeres, sino una capucha a la que su madre le recortó agujeros para los ojos. Hassan viene de un pueblo al pie del Atlas. Como casi todos los habitantes de la montaña pertenece a los beréberes kabiles que desde los tiempos de Heródoto habitan el África del norte. Habiendo resistido a árabes y franceses durante siglos, su madre y su tía llevaron al muchacho herido de muerte a Argel para que recibiera ayuda médica. El ejército había interceptado caminos con barricadas y los terroristas islamistas disparaban a buses y camiones. Una mañana, hacía dos meses, él muchacho fue a buscar agua y no volvió más. En la penumbra del alba, un francotirador lo confundió con un soldado y le disparó, tal vez lo hizo como represalia debido a que los habitantes del pueblo no dieron a los combatientes islamistas los alimentos prometidos. La bala penetró en la nuca, al lado de la oreja, y salió por la raíz de la nariz. Aunque no hirió ningún órgano vital, el nervio óptico fue lesionado y Hassan quedó ciego de un ojo. En lugar de nariz tiene una herida abierta cuyo aspecto es tan horrible que durante el día la cubre con un paño. Los niños del pueblo se niegan a jugar con él y sus propios hermanos no soportan su presencia. Hassan respira por la boca, pero la inflamación se trasladó de la nariz a la cavidad bucal y le es difícil tragar. Su ojo sano también está supurado y su visión disminuye rápidamente. La tía de Hassan pregunta en un francés, con acento lugareño, si deseamos hacer fotos, y la reportera de televisión que me acompaña asiente, da una señal a su camarógrafo y la madre levanta el paño. En el rostro de Hassan hay un agujero, al verlo tengo que cerrar los ojos. Mientras la madre seca el pus de la herida, la reportera comenta que en Bruselas hay una clínica especializada en cirugía plástica donde podrían rehacer la nariz a Hassan. Ella quiere hacer una colecta a través de los telespectadores belgas para financiar la operación. Para eso se necesitaría que las formalidades de salida e ingreso del territorio fuesen sin trámite burocrático, un deseo irrealizable debido a la rigidez del régimen militar argelino. Quiero que él mismo me diga lo que quiere ser cuando grande. La tía traduce mi pregunta al kabil. “Médico”, dice Hassan, y no queda claro si solloza o traga sangre por su herida. Quiere ser médico para ahorrarles a otros niños lo que él debe sufrir. 
“La existencia de lo terrible en cada partícula del aire”, escribe Rilke en su novela Los Cuadernos de Malte Laurids Brigge, publicada en 1910, donde articula experiencias limítrofes semejantes: "Pues todo lo que en tormentos y torturas se haya dado en lugares de suplicio, en cámaras de la Inquisición, en manicomios, en salas de operación, bajo los arcos de los puentes, al final del otoño; todo esto es de una tenaz intemporalidad. Todo esto subsiste y depende, celoso de todo ser, de su espantosa realidad”.

\section{MARAT}

(Se dirige a Sade por encima de la plataforma, ahora desierta)

Yo te leí una vez Sade

en uno de tus escritos inmortales

que el principio de toda vida estaría en la muerte

SADE

Y esa muerte sólo existe en la imaginación;

sólo nosotros somos los que tenemos esa idea.

La Naturaleza no la conoce.

Hasta la más cruel de todas las muertes

se abisma en la indiferencia absoluta de la Naturaleza.

Sólo nosotros otorgamos a nuestra vida cierta importancia.

La naturaleza podría asistir sin inmutarse

al exterminio de la raza humana

(...)

MARAT

Al silencio de la Naturaleza

opongo yo mi acción.

En la indiferencia universal

hago surgir un sentido.

En vez de ser un testigo apático

yo intervengo

y nombro ciertas cosas como falsas

y trabajo por cambiarlas y corregirlas $(. . .)^{\mathrm{xxiii}}$.

El drama de Peter Weiss, de donde se extrajo este diálogo, fue un caso único para el teatro de lengua alemana. Pero la obra prescinde de toda acción dramática y se asemeja más bien a un coitus interruptus: Marat en la bañera y Sade enfermo en un manicomio declamando su texto histórico universal. La dirección de la puesta en escena siempre vuelve a retener el brazo que Charlotte Corday mantiene levantado para asestar el golpe mortal, pues aún no se ha dicho todo. A diferencia de las piezas unidimensionales

xxiii Se tuvo a la vista la traducción de Alfonso Sastre del libro de Peter Weiss, Persecución y Asesinato de Jean-Paul Marat, traducción y adaptación teatral (Barcelona: Grijalbo, 1969), pp. 74, 77 s. (N. del T.). 
que Peter Weiss escribió después de su conversión al marxismo, no sólo transpuso aquí el espíritu revolucionario de los años 60 sino también sus obsesiones personales y políticas, llegando a la fascinación erótica de la violencia que se extiende como subtexto por toda su obra. Ya en la puesta en escena de Hans Anselm Perten, en la RDA, Sade fue presentado como un décadent aristocrático; Marat personifica el progreso al que se le otorga razón de modo parcial. Peter Weiss no tuvo objeción alguna, pues aquello correspondía a la posición ideológica que en el intertanto había adoptado. Como es frecuente en la literatura, el texto es más complejo e inteligente que el pensamiento no dialéctico del autor: ambos adversarios del drama tienen razón y se equivocan a la vez; la verdad no está simplemente al medio, entre Marat y el marqués de Sade. Hoy se podría pensar que esta posición no solamente es la más radical sino que la más esclarecida, pues reduce la historia a una cadena de actos atroces cuyo único 'sentido' es generar placer a sus autores. Sade pone al descubierto la crueldad fundamental en la que se basa toda comunidad humana — lo que se llama el monopolio de la violencia-, inmunizándose, a sí mismo a la vez que a sus lectores, contra la realización de su crueldad. En sus fantasías sexuales, Sade pone en escena sus orgías sangrientas, pero retrocede con horror ante la realidad política de dichas prácticas; se espanta ante el terror jacobino, y convertido en miembro de un tribunal revolucionario intercede a favor del indulto de un condenado a muerte:

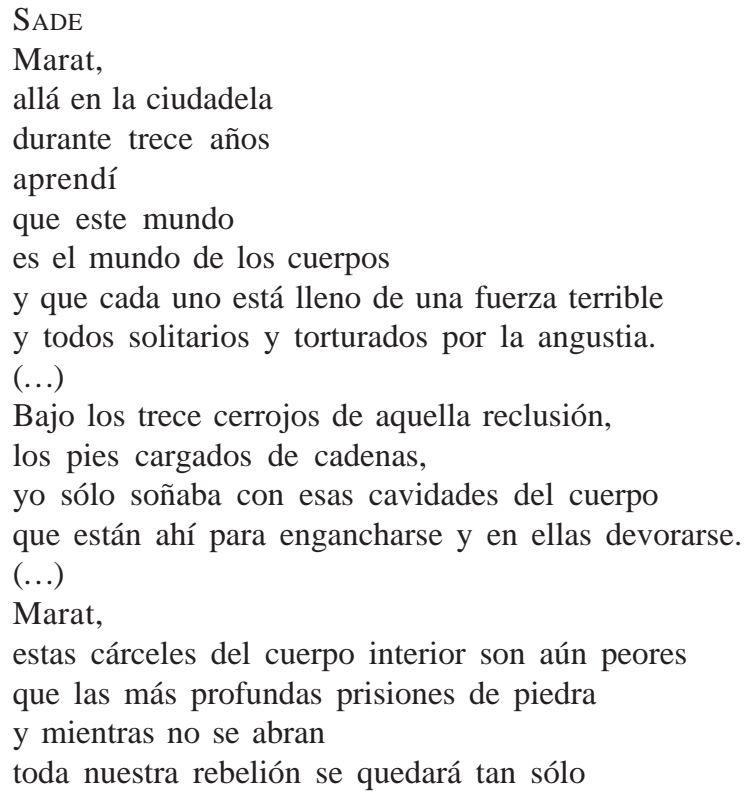


en un motín de presos aplastado

por compañeros de celda sobornados $(\ldots)^{\mathrm{xxiv}}$.

La verdad que Sade convoca con su nombre es más perturbadora que cualquier teoría de conspiración ideológica. Para él, las reglas de los conflictos militares o políticos sólo son pretextos para el desencadenamiento de un potencial de agresión y destrucción que duerme bajo la cubierta de la civilización y del cual ésta se sirve (y lo hace manifiesto) en cada ocasión apropiada; un diagnóstico que confirma el análisis del totalitarismo moderno: "el asesinato no es una consecuencia de segundo orden, sino el verdadero programa del totalitarismo. El retorno a la muerte significa un retorno a la médula de nuestra existencia, una piedad arcaica y terrible: lo brutal como escapatoria a lo banal”, escribió Alexander Schuller en la revista Merkur, en un estudio comparado de asesinatos masivos perpetrados por el estalinismo y el holocausto nazi que aparecieron documentados en El Libro Negro del Comunismo. Ya en los años 30 Elías Canetti llegó a las mismas conclusiones cuando describió a Adolfo Hitler como el único político de la República de Weimar que les prometió fidelidad a los caídos de la Primera Guerra Mundial, programa que sólo se llevó a efecto cuando Hitler incrementó el volumen de muertos al iniciar una nueva guerra. Lo fascinante en el gran ensayo de Canetti sobre Masa y Poder, en el que se pueden seguir estas reflexiones, es que razona sin hacer referencia al marxismo ni al psicoanálisis, ya que no necesita rendir honores a la lucha de clases marxista ni al instinto de muerte freudiano.

A finales de los años 70 asistí en un barrio de Río de Janeiro a una ceremonia de Umbanda. La Umbanda que se practica masivamente en Brasil es una religión que mezcla elementos del culto vudú originario de África occidental — llamado Macumba en Río de Janeiro - y la doctrina espiritista de Allan Kardec. La tumba del espiritista, en el cementerio parisino Père Lachaise, está siempre adornada con velas y flores, y los seguidores del ocultismo vienen del mundo entero a encontrarse aquí. Allan Kardec era un contemporáneo de Karl Marx y cuando entré al templo, situado en la calle más animada de Niteroi, pensé que me había equivocado de dirección y que estaba en un local del Partido Comunista. Los retratos monumentales de un hombre con barba rizada, un cruce entre Marx y Engels, flameaban como banderas en el viento tibio que entraba a través de las ventanas abiertas; un gentío extático que cantaba y bailaba me empujó hacia el altar, donde una

xxiv Traducción basada en la de Alfonso Sastre. Véase nota xxiii, supra. 
sacerdotisa vestida de blanco murmuraba letanías rítmicas y me bendecía con una rama de palmera. Después de esto me sentí milagrosamente renovado, refrescado y tuve una fuerte repulsión contra la nicotina y el alcohol. La magia había hecho su efecto, pues según el consejo de un amigo brasileño, yo había viajado a Niteroi para quitarme la costumbre de fumar. Después de la ceremonia fui llevado a un cuarto trasero y se me presentó a la sacerdotisa de Umbanda, cuyo nombre olvidé; lo único que recuerdo es que tenía los cabellos teñidos de rubio y ojos azules, pese a su color de piel oscuro.

La conversación desembocó, ignoro el motivo, sobre la Alemania nazi. La sacerdotisa quería saber si estaba yo en conocimiento de que el partido nazi NSDAP era una secta oculta, mejor dicho, de un culto de la muerte. La cruz gamada era una rueda del sol invertida, es decir, un símbolo de vida puesto al revés, y los uniformes negros de la SS con la calavera en la gorra hacían evidente alusión a la meta secreta del movimiento, incrementar la masa de los muertos. A eso se debían la guerra total, los campos de concentración, el Holocausto y la última orden de Hitler antes de suicidarse: destruir Alemania. Me fue difícil resistirme a la lógica de su argumentación, pues lo que parecía a primera vista una charlatanería supersticiosa, al examinarlo más de cerca coincidía con los descubrimientos de psicoanalistas como Erich Fromm, cuyos libros la sacerdotisa de Umbanda seguramente no había leído.

El carácter pseudo-religioso de la ideología nacional-socialista (nazi) ha sido continuamente confirmado, al igual que la contradicción entre su irracionalismo arcaico y los medios modernos que Hitler y Goebbels utilizaron para la difusión de su propaganda. Pero en el centro de la ceremonia de este culto de la muerte no estaban las mascaradas medievales y místicas que Himmler puso en escena en el castillo de caballeros de la SS, sino aquellos actos que se desarrollaron en su centro secreto, el lugar de los asesinatos del campo de concentración:

Delante de ellos se elevaba un bello edificio de madera ornamentada al estilo de un antiguo templo, cinco anchas gradas de hormigón conducían a unas puertas bajas, pero muy anchas, macizas y bien trabajadas. Delante de la entrada había flores en maceteros; sin embargo, alrededor reinaba el caos, de todas partes se veían montañas de tierra excavada. (...) Las anchas puertas de la casa de la muerte se abrían lentamente y dos ayudantes de Schmitt, el jefe de la empresa, aparecieron en la entrada. Simultáneamente los SS soltaron los perros amaestrados que se lanzaron hacia la multitud, encarnizando sus dientes sobre los cuerpos desnudos de los pri- 
sioneros condenados a muerte. Bajo gritos salvajes, los SS golpeaban con la culata de sus rifles a las mujeres, afectadas por lo que parecían contracciones convulsivas, haciéndolas avanzar. En el interior del edificio estaban los subalternos de Schmitt ejecutando la obra, empujaban a la gente por las puertas abiertas de las cámaras de gas. (...) Esto se repetía dos, tres, cuatro y hasta cinco veces por día. Treblinka no era un lugar de ejecución cualquiera, se trataba de una empresa de asesinatos a destajo.

He citado este texto de manera extensa porque surgió bajo la impresión inmediata del acontecimiento. Su autor, Vasily Grossman, oficial del Ejército Rojo, visitó el campo de Treblinka poco después de su liberación en septiembre de 1944. Su informe El Infierno de Treblinka apareció en 1947 en Moscú, en una editorial de literatura para lenguas extranjeras. La administración militar soviética lo difundió en grandes tirajes en la tardía RDA, antes de que el autor cayera en desgracia por Stalin. Vasily Grossman murió en 1964; su novela de guerra, Leben und Schicksal (Vida y destino), estuvo veinte años bajo llave y fue publicada en Occidente póstumamente. La pretensión de lo políticamente correcto que hoy gravita sobre cualquier discurso acerca del Holocausto, haciendo que cada escrito sobre este tema se convierta en una fatigosa danza para evitar suspicacias, no existía todavía en aquella época, a pesar o a causa de la censura omnipresente del estalinismo. Más tarde apareció en primer plano la pregunta de Theodor W. Adorno sobre la manera correcta de superar el pasado, cuestión que en el debate de los historiadores alemanes condujo a situaciones absurdas: al absurdo de que por miedo a relativizar o tomar a la ligera el exterminio de los judíos, éste no debe compararse con ningún otro genocidio. Si al Holocausto no se lo debe comparar, entonces no se lo puede comprender y queda fuera de la Historia, lo contrario de lo que Adorno entendía por elaboración crítica del pasado. En comparación, el texto de Vasily Grossman, dictado por los propios acontecimientos, formula ambos rasgos de este problema: el horror elemental ante una realidad que sobrepasa la facultad del entendimiento humano y, asimismo, las conclusiones elementales que el reportero resume:

Con los sobrevivientes del ghetto de Varsovia, los SS practicaban un juego atroz. Las madres, trastornadas por el horror, debían llevar a sus hijos a las parrillas ardientes sobre las que miles de cuerpos muertos se retorcían en las llamas y el humo, y los cadáveres se crispaban como si revivieran. (...) Imágenes que Dante jamás pudo ver para su Infierno. Es infinitamente difícil leer aquellos textos. Ojalá el lector pueda creer 
que no es menos difícil escribirlo. Referir una verdad terrible es el deber de un escritor, así como el deber cívico del lector es conocerla. Todo aquel que se desvía, cerrando los ojos para pasarla por alto, hiere la memoria de los asesinados.

La mirada precisa de Grossman y la denuncia moral que se deduce de ella coinciden casi literalmente con las reflexiones de un autor que se sitúa al otro extremo del espectro ideológico y del cual uno no esperaría dichas ideas. El ensayo de Ernst Jünger, Der Friede ${ }^{\mathrm{xxv}}$ (La Paz), fue escrito 1945, en la misma época que el relato sobre Treblinka de Vasily Grossman, después del atentado fallido contra Hitler y el desembarco de los aliados en Normandía. Jünger rebate al pasar la hasta hoy difundida leyenda de que la Wehrmacht se había comportado de manera "correcta” y que la mayoría de los alemanes no sabía nada: "Sólo sombras de rumores anunciaban las horrorosas fiestas en las que esbirros y verdugos se saciaban del miedo, del envilecimiento y de la sangre de sus víctimas. Esto quedará como una lacra a lo largo de nuestros siglos; no se podrá respetar a quien haya carecido de corazón y ojos para ver lo que allí pasó. Esto vale particularmente para la juventud guerrera (...). Lo oculto, la lejanía de la claridad, las masacres en los sótanos y en los lugares de desgracia y el ocultamiento de las víctimas, delataron claramente que no se trataba de la ejecución de veredictos justos y que en los ultrajantes asesinatos se actuó con genuino perjurio (...). Estos antros de la muerte perdurarán a través de los tiempos en la memoria de los hombres; éstos son los verdaderos monumentos conmemorativos de la guerra, como anteriormente lo fueron Douaumont y Langemarck”.

Si bien la mujer de Río fue algo visionaria, no se trataba de una clarividente, pues el sortilegio del vudú me sanó sólo provisoriamente: el deseo de la nicotina fue más fuerte que el culto de la Umbanda. Quince años más tarde - entretanto perdí el hábito de fumar- adopté otra adicción que todavía hoy me da que hacer. La fascinación negativa de la violencia tiene el efecto de una enfermedad contagiosa que no sólo afecta a víctimas y victimarios, sino también a asistentes humanitarios y periodistas observadores de una guerra. Como con todas las drogas, su efecto disminuye con el tiempo —embotamiento y embrutecimiento, se podría decir- y entonces se debe aumentar la dosis. Todo comenzó con lo que expertos, médicos y psicólogos, denominan “síndrome postraumático”; igualmente se podría llamar fenómeno de supresión. A mi regreso me sentía abatido, irritable y

xxv Ernst Jünger, Der Friede. Ein Wort an die Jugend Europas und an die Jugend der Welt (La Paz. Una palabra a la juventud de Europa y del Mundo), Amsterdam: Erasmus Verlag, 1946 (N. del T.) 
nervioso. Sufría de insomnio y pesadillas, noche tras noche se repetía lo que había visto y vivido. Mientras más terribles habían sido mis experiencias, más torturantes eran las pesadillas. A preguntas bien intencionadas yo reaccionaba agresivo o las eludía. No tenía ganas de explicar a personas que nada comprendían o que no querían saber verdaderamente lo que significa presenciar la apertura de una fosa común. Explicar es la palabra equivocada, pues se trataba de experiencias que no se dejan resumir en una o dos frases. De otra manera hubiese tenido que contar la historia; sin darme cuenta, habría sobrepasado la paciencia de mis auditores. Para contar siempre falta tiempo. Los debates públicos en la República Federal sobre la prolongación de la hora de apertura de los almacenes, la legalización de las parejas homosexuales, los pros y contras de la reforma de la ortografía, no sólo me parecían una banalidad, sino frivolidades ante los niños hambrientos en Sudán y los cadáveres descompuestos en las calles de Monrovia. Mi capacidad de establecer contacto social estaba perturbada, incapaz de conversar de lo que había vivido, peor aún, incapaz de escuchar a los otros, me aislé de mis amigos y conocidos. Cada vez que se golpeaba una puerta o un motor tenía un encendido defectuoso, me cobijaba y recogía mi cabeza con temor. En una mesa redonda me sorprendí imaginando un atentado con bomba, junto a los cuerpos destrozados de los asistentes del foro. Las ciudades destruidas me parecían normales; por el contrario, percibía los edificios intactos como escenografías de teatro. La presión se aligeraba cuando descendía del avión en una zona de guerra y podía ver delante de mí restos de carrocerías de autos, tanques, cráteres de bombas o las fachadas perforadas por los impactos.

Eso era la verdadera realidad, el resto era una ilusión sin consistencia; de repente, tenía la sensación de haber llegado a casa.

Los síntomas de esa perturbación son conocidos. Fueron registrados y analizados por primera vez cuando miles de soldados americanos que habían visto y vivido cosas mucho peores que yo regresaron de Vietnam marcados por un estrés postraumático que hizo difícil y muchas veces imposible su reinserción en la vida civil. A diferencia de esos reclutas yo había partido voluntariamente al frente. Alexander Schuller da indicaciones que permiten comprender este comportamiento que limita en el masoquismo, en un ensayo publicado por el Merkur: Von der Habgier zur Gefühlsgier (De la avaricia a la concupiscencia): "La adicción reconcilia los contrarios aparentes, crea orden y éxtasis a la vez. Libera al adicto de todas las obligaciones sociales $\mathrm{y}$, al mismo tiempo, lo somete a una dependencia sin tregua ni cuartel. En ninguna parte — excepto en el totalitarismo— la desinhibición y el terror están ligados tan estrechamente”. 
Dos caminos permiten la cura de la adicción: la lenta pérdida del hábito o la privación brutal. Para mí, no venían al caso. Es posible comparar la destrucción en un segundo de una casa, cuya reconstrucción tarda meses y años, con alguien que al mirar el rostro de la medusa, no puede continuar viviendo como antes ni olvidar lo que vio. Tampoco podía esperar ayuda de los psicólogos que reaniman a policías y a bomberos traumatizados por sus intervenciones en las catástrofes y que los alientan a relatar lo vivido. Mi medio de sanación era la literatura. Con esto no me refiero a los bestsellers de temporada o a los últimos libros de culto de la nueva generación, sino a la literatura mundial: Kleist, Goethe, Stendhal, Tolstoi, para citar algunos nombres. En sus obras no encontré respuestas a las preguntas que me conmovían y perturbaban, pero estaban planteadas de tal manera que me abrían un camino posible a la reflexión. La violencia mortífera, en la que se basa toda comunidad social, dejaba de ser tabú y, en un suspiro, se transformaba estéticamente en un lenguaje que siendo terrible y bello a la vez, no se dejaba reducir a conceptos abstractos. Un ejemplo de la capacidad de la literatura de traspasar su dependencia histórica y obrar como si el texto, aquí y ahora, estuviera especialmente hecho para ti, es la parábola de Lu Xun (Lu Hsin), a quien denominan el Gorki chino. Lu Xun escribió su libro bajo pseudónimo y, como Gorki, cuyo nombre significa amargo, no pudo suprimir sus dudas y su melancolía, convirtiéndolas en literatura fecunda, al contrario del optimismo falaz de la doctrina oficial del partido del que fueron víctimas los amigos y discípulos de Lu Xun después de su muerte.

Lu Xun murió en 1936 en Shangai, mucho antes de la victoria del Ejército Rojo y la fundación de la República Popular. El siguiente poema en prosa se extrajo de la colección de textos Wilde Gräser (Mala hierba) que fueron prohibidos durante la Revolución Cultural por su tónica fundamentalmente pesimista, en los que se entregan reglas y ejemplos de aquello que intenté exponer en las páginas precedentes. Se trata de matarifes y voyeuristas de sexo y violencia, de asesinos y espectadores. Debido a la falta de espacio cito el texto abreviado:

La piel de un ser humano probablemente tiene apenas medio milímetro de espesor; por debajo circula una red muy densa de vasos sanguíneos, más densa que el hormigueo de los gusanos de seda cuando trepan unos sobre otros para remontar el muro de sangre radiante de calor (...). Pero con la sola puñalada de un chuchillo puntiagudo, a través de la delgada piel color de durazno, la sangre caliente y roja brota como una flecha, esparciendo inmediatamente el calor sobre el ejecutor. Es así 
como ambos están cara a cara con los cuerpos desnudos en el desierto abandonado, blandiendo cuchillos cortantes. Ellos se abrazarán el uno al otro; ellos se degollarán el uno al otro.

De todos lados los transeúntes se aglomeran apresurados como gusanos de seda trepando un muro, con sabor a sudor y a sangre en la lengua, estirando el cuello con avidez para saciarse en la mirada de un abrazo o un degüello.

Sin embargo, los dos que están frente a frente en el vasto desierto, con sus cuerpos desnudos, blandiendo cuchillos cortantes, no se abrazan ni se matan. Los transeúntes se aburren. Sus gargantas y lenguas se secan, sus cuellos se ponen tiesos. Finalmente se miran embobados y paulatinamente se dispersan.

Todo lo que queda después es el vasto desierto y los dos, con sus cuerpos desnudos, frente a frente blandiendo cuchillos cortantes. Con los ojos desvaídos, como de muertos, ante el marasmo de los transeúntes se sacian en su degüello sin sangre, elevándose para siempre en el extremo y supremo arrobamiento extático de la vida.

\section{II}

La comunidad internacional, que ante cada crisis política o catástrofe humanitaria (¡una de esas expresiones que no existían hace algunos años!) se invoca ampulosamente, es una piadosa ficción que aparece periódicamente cuando el Consejo de Seguridad de la ONU tiene sesión y, ante la falta de una estrategia común de los Estados miembros, decide sanciones. Estas sanciones dañan siempre a la población que se halla en crisis y no afecta a los dirigentes de cuyas garras debe ser rescatada; la nomenklatura dominante elude con facilidad el embargo de armas o el bloqueo económico, lucra con la escasez, se enriquece con el contrabando y consolida así su poder. Miloševiæ y Saddam Hussein son los más conocidos, pero también otros regímenes impopulares en Occidente se hallan en la lista de los Estados infames: Irán, Afganistán, Libia, por nombrar sólo a los más conspicuos. Por el contrario, el escritor y ex espía John Le Carré observa que no hay ángeles ni demonios en la arena de la política mundial, sólo semi-ángeles que luchan contra semi-demonios.

Por más que las sanciones sean contraproducentes, la comunidad internacional se atiene a este medio poco apropiado, porque un embargo económico es menos dispendioso que una intervención armada que no sólo representa un gasto de dinero sino de vidas humanas. No se trata de la vida 
de los soldados o civiles del bando enemigo, que ni siquiera aparecen en los cálculos militares, sino de las propias pérdidas que deben mantenerse lo más reducidas posible: zero casualty (cero víctimas), es la nueva doctrina militar americana, aplicada por primera vez en Grenada (isla-país en el mar Caribe). Además, un embargo no polariza a los telespectadores. Puesto que en la democracia mediática la apariencia es más importante que la esencia, queda la impresión de que los responsables políticos hacen todo lo humanamente posible. Porque a diferencia de lo que se quiere hacer creer a la opinión pública, las crisis o conflictos armados no terminan automáticamente con el envío de observadores de la ONU o el estacionamiento de tropas de Cascos Azules, más bien, pasan a otro plano: es entonces cuando realmente comienzan las dificultades. Así como en la vida privada, la regla no resuelve los problemas; después de un tiempo éstos se desplazan hacia otros peores y más difíciles de resolver. Para ello un ejemplo.

A mitad de junio de 1995, sonó el teléfono en mi habitación del hotel Intercontinental en Zagreb. Era mi primera visita a la antigua Yugoslavia. Dos horas antes había aterrizado en el aeropuerto y la conversación con el chofer de taxi que me condujo a la ciudad fue una degustación de lo que me esperaba. "Hier nix Balkan, hier Europa" (Aquí no Balcanes, aquí Europa). Con esta información, transmitida en un excelente alemán de trabajador inmigrante, el chofer — creo que se llamaba Bogdan— entabló conversación. Sin perder de vista la ruta, volteó y me miró, quería saber si yo tenía en Berlín un departamento. “¿Tú hacer limpieza departamento Alemania? Nosotros también hacemos limpieza departamento Croacia”. Durante una temeraria maniobra para adelantar, Bogdan dijo que no tenía nada en contra de serbios ni bosniacos, al contrario, tenía amigos y parientes en todas las repúblicas de Yugoslavia, pero el canto de los monjes serbios no le gustaba. ¿Había estado yo alguna vez en una iglesia ortodoxa? Los serbios son cristianos, pero su música es insoportable, igual que la hediondez en una mezquita frecuentada por bosniacos. ¿Había estado yo alguna vez en una mezquita durante el oficio religioso? El olor hace llorar las piedras, porque los fieles, antes de entrar a la mezquita deben sacarse sus zapatos y la mayoría de los habitantes de los Balcanes no se lavan los pies. Entonces comprendí que por limpieza, él entendía "purificación étnica”. La observación del chofer se refería a la Krajina, por la cual el ejército croata había expulsado a los serbios que vivían allí. Como muchos racistas, Bogdan tenía una apariencia más bondadosa y jovial que fanática y agresiva, sus ideas parecían tan normales que se indignó cuando objeté que era un extremista. “¿Tú hambre?”, me preguntó repentinamente, deteniéndose ante un meren- 
dero situado en las afueras de la ciudad. “¿Cuántos kilos?” La especialidad del restaurante era cordero asado; no se vendía en porciones, sino en kilos. Pedí doscientos cincuenta gramos, Bogdan opinó que era demasiado poco, lo mínimo era una libra por persona. La carne era exquisita, el Loza también —en Croacia no se bebe slibovitz, sino aguardiente de orujo- . Bogdan insistió en vaciar una botella entera conmigo. Su hospitalidad no toleraba contradicciones y era despótica, esto se reflejaba en la alcoholización forzada, como en otros tiempos, en la Unión Soviética.

"Hier nix Europa, hier Balkan" (Aquí no Europa, aquí Balcanes), balbuceé solo y ebrio sobre la cama, con mis maletas sin abrir, cuando sonó el teléfono. La agregada de prensa del delegado de la ONU en la antigua Yugoslavia — quizás aún era su secretaria—me invitó a un encuentro informal de intercambio de opiniones con Yasushi Akashi y el general Janvier, comandante de las tropas de Cascos Azules, en el Cuartel General Militar de las Naciones Unidas.

"Nosotros estamos en una guerra, pero no estamos en guerra", dijo el diplomático japonés de las Naciones Unidas, primero en francés y después en inglés, mirándome ansiosamente para asegurarse de que yo había comprendido bien la sutileza de su declaración. El general Janvier hizo un gesto afirmativo con la cabeza. En las últimas semanas, el ejército bosnioserbio había tomado como rehenes a cien soldados de Cascos Azules. Algunos oficiales de la ONU reclamaron que órdenes venidas desde arriba les impidieron intervenir. Una parte de la prensa dejó entrever suposiciones de que había divergencias de opinión entre las tropas locales de los Cascos Azules y el Secretario General de la ONU en Nueva York. Para desmentir estos rumores es que Akashi, de carácter tímido y reservado, me había llamado a mi llegada. Estaba harto, decía el general Janvier, mientras garabateaba figuras de hombrecitos en su libro de apuntes, de que a él y sus soldados se les acusara de falta de fuerza y eficacia mientras arriesgaban la vida diariamente. Por la limitación de su mandato estarían con las manos atadas, pero en el futuro la "Rapid Reaction Force" (Fuerza de intervención rápida), supeditada a su Comandancia, impediría del todo las violaciones del armisticio y las trabas a la circulación de convoyes humanitarios. A la pregunta de si esto incluía la apertura a la fuerza del corredor aéreo que conduce a Sarajevo, bloqueado por el ejército bosnio-serbio, respondió evasivamente: caso por caso será examinado y dependerá de las proporciones de los medios; como es sabido, una tropa de paz no es un bando en guerra.

"La ONU no se cruza de brazos", decía Akashi, mientras su secretaria traía una bandeja con tazas de café y galletas. "Yo estoy en contacto con todos los bandos del conflicto y llamo por teléfono diariamente a mi amigo 
el Dr. Radovan Karadzie para convencerlo de liberar a los Cascos Azules secuestrados como rehenes. El Dr. Karad•iæ se mostró siempre cooperador conmigo”.

Más revelador que el propósito fue la manera en que el responsable de la misión de la ONU me lo decía. Aquella expresión lo traicionaba: “mi amigo el Dr. Karadzie”. Akashi no sólo había sobrevalorado diplomáticamente al lord de la guerra en Pale, responsable de sumir a los habitantes de Sarajevo en un sufrimiento sin fin. Había confirmado involuntariamente todo lo que había querido desmentir de manera oficial: que la ONU era un tigre de papel que se limitaba a protestas sin efecto, en lugar de impedir por medio de una intervención enérgica los asesinatos perpetrados en Bosnia. La convención de Dayton aún estaba lejos.

De camino al aeropuerto, la conversación trató sobre otro doctor. “Algo raro está pasando”, dijo Bogdan, que me esperaba en su taxi, delante de la sede de las Naciones Unidas, en una calle con barricadas de sacos de arena y alambres de púas. “Algo raro está pasando aquí, pues hace una hora y media que el Dr. Franjo Tudjman no se menciona más en la radio. Normalmente su nombre aparece cada dos frases: Dr. Franjo Tudjman ha inaugurado un jardín de infantes, una iglesia o un colegio; Dr. Franjo Tudjman ha telefoneado a la Casa Blanca en Washington, la hija de Dr. Franjo Tudjman ha inspeccionado el Duty-free-Shop en el aeropuerto. Y ahora esto, como si nuestro presidente hubiera desaparecido sin dejar huellas, como si se hubiese disuelto en el aire. ¡Ojalá que no le haya pasado nada grave!”

El temor del chofer era prematuro, pues Tudjman no murió sino cuatro años más tarde en el hospital de Zagreb, luego de una operación de cáncer efectuada en secreto en los Estados Unidos. Sólo tras su muerte empezó a circular lo que los conocedores del país denunciaran en vano años después: el dictador de Croacia, que había comenzado su ascenso político disimulando las masacres perpetradas por los ustacha fascistas y ocultando el número de víctimas, no había sido mejor que el criminal de guerra Karadzie. Títulos de doctores no son garantía contra atentados a los derechos humanos; esto no es así sólo en la ex Yugoslavia.

Nada sucede como uno lo espera, dice un antiguo proverbio. Eso vale para territorios en guerra y en crisis, donde el conocimiento adquirido en los libros se revela a primera vista, no ciertamente falso, pero sí insuficiente. En el lugar, todo es diferente de lo que uno imagina a través de las informaciones de catástrofes. Esto comienza ya con la gente denominada por los medios como víctimas o afectados, quienes nunca aparecen con 
expresión fúnebre, sino que sonríen y se muestran más alegres que sus congéneres de los países donantes, que preocupados por su bienestar y seguridad han terminado por perder la espontaneidad. Me he preguntado hace tiempo a qué se debe esto. ¿Es una característica de las sociedades pre-industriales, cuya amabilidad no depende aún del cálculo económico, o es que las personas se acercan unas a otras para defenderse ante el peligro que los amenaza a todos por igual? En los refugios antiaéreos de la Segunda Guerra Mundial, en los comedores diarios de la RDA, había una solidaridad semejante, que en tiempos menos difíciles se evocaba con nostalgia.

Un indicador de las alteraciones psíquicas que ocasionan las presiones externas se revela en el comportamiento de reporteros y periodistas, cuya vida cotidiana profesional generalmente se caracteriza por una competencia despiadada. Sin embargo, en una situación de crisis, como en Monrovia, donde se enfrentaban los bandos armados de la guerra civil, en lugar de la rivalidad brutal había solidaridad y acotada colaboración. Nació una extraña camaradería que daría paso a un humor negro para hacer más soportable las amenazas provenientes del exterior. La US-Navy había evacuado a casi todos los extranjeros de Liberia, muchos de ellos comerciantes libaneses que subían a helicópteros con maletas llenas de diamantes de contrabando, como narraban con envidia los mal pagados marines americanos. Hoteles y restaurantes, negocios y oficinas de organizaciones humanitarias fueron incendiadas y arrasadas. Tan sólo en el hotel Mamba Point, cuyo propietario libanés había sobornado a los dirigentes de los ejércitos de la guerra civil por 50.000 dólares, según rumores, se había reunido un puñado de audaces fotógrafos y periodistas. Hacía semanas que la ciudad y sus alrededores carecían ya de agua y de luz; en la noche se escuchaban balazos y explosiones de granadas, que se acercaban lentamente, mientras los clientes del hotel bebían champaña saqueado del Duty-free del aeropuerto. Después de medianoche, cuando el generador del hotel sufría un apagón, se servía Johnnie Walker Blue Label, una marca de lujo que jamás volví a probar fuera de la Monrovia destruida. No había arroz, ni pan, ni carne, ni pescado, sin embargo el congelador del hotel estaba repleto de langostas que se preparaban cada noche de una forma diferente: asada a la parrilla, dorada con mantequilla o al estilo thermidor. En su diario titulado Strahlungen (Diarios parisinos), Ernst Jünger describe delicias culinarias semejantes durante la retirada de la Wehrmacht de París, como si la guerra pusiera de relieve de manera aún más extrema que lo habitual el contraste entre la miseria de la mayoría y la vida lujosa de una minoría privilegiada.

El héroe del día era un francés, fotógrafo aficionado, que había llegado a Liberia para aprender inglés antes de que estallaran los combates. No 
es broma, como se podría pensar, fue realmente así. Los niños soldados del FNPL de Charles Taylor lo habían aceptado en sus filas como miembro de honor y compartían con él sus cigarrillos de marihuana, hasta que el fotógrafo aficionado fue herido en un intercambio de disparos. Los bandos beligerantes cesaron provisoriamente el fuego y sus colegas reporteros, arriesgando la vida, cargaron al herido en un carretón y lo trasladaron al hotel donde se celebró con champaña su salvación. Después de ser evacuado por la US Navy se formó una leyenda heroica en torno a este fotógrafo aficionado. Se decía que habría llegado al último círculo del infierno, mientras que los otros periodistas tan sólo habían alcanzado el limbo: la verdadera vida $\longrightarrow \mathrm{o}$ la verdadera muerte $—$ presuntamente tiene lugar en otra parte.

Lo opuesto al fotógrafo aficionado, respetado en todas partes, fue John McWethy, el corresponsal del canal de televisión ABC, que sólo tuvo una pequeña actuación entre los periodistas reunidos en el Mamba Point. Una mañana, poco después del amanecer, un vehículo anfibio de la US Navy se detuvo delante de la entrada del hotel escoltado por un jeep, cuyos pasajeros, francotiradores con chalecos antibalas, habían cercado la calle a la redonda. Un reportero pelirrojo y pecoso se bajó de la tanqueta y corrió zigzagueando de un muro a otro hasta el hotel, mientras sus protectores dirigían sus fusiles telescópicos a las ruinas del entorno, de donde salía un fino humo. Nada parecía fuera de lugar, excepto una madre joven que lavaba a su bebé en un badén al borde de la calle y un niño desnudo, que con un largo palo trataba de hacer caer de las ramas algunos mangos aún no maduros. Los combatientes de la FNPL, atrincherados detrás del próximo cruce, a esta hora dormían. Todos los empleados del hotel y clientes del Mamba lo sabían y se lo podrían haber dicho a los americanos, pero los marines no debían arriesgarse porque transportaban un bien precioso, McWethy, uno de los célebres periodistas de la televisión de Estados Unidos. Parecía haber emergido de una película de James Bond, llevaba un casco tropical, un mosquitero y un chaleco safari con numerosas cremalleras, lazos y bolsillos que contenían un survival kit completo, con medicamentos contra la fiebre amarilla y malaria hasta raciones para sobrevivir en el desierto o en la selva, cohetes de señalización y aparatos para la visión nocturna. Pero a diferencia de los fotógrafos franceses o al equipo de televisión de Sudáfrica que hablaban distintas lenguas - familiarizados con muchos territorios en guerra-, McWethy sólo hablaba inglés y se encontraba por primera vez en África. Durante las dieciocho horas de su estadía en Monrovia estuvo constantemente conectado con su redacción por teléfono satelital y nunca salió del hotel, burlándose de la osadía de sus compañeros reporteros que 
asumían un riesgo calculado patrullando la ciudad en grupos. Sin embargo, durante la noche en el bar, él se dejaba contar todo detalladamente y después lo transmitía en vivo a Washington como si él mismo hubiese vivenciado los combates de Monrovia.

$\mathrm{Al}$ amanecer hubo una explosión, de granadas, que a través de la ventana parecía una violenta tormenta de truenos y relámpagos. La milicia Krahn, surgida del ejército del gobierno liberiano, había tomado por asalto una posición de la FNPL y ocupado la ruta que conducía al Mamba Point; dos niños soldados muertos yacían sobre el césped delante del hotel. Poco después de la salida del sol se presentó un blindado de la US Navy para llevar al corresponsal del Pentágono. "Duck and dive" (Agacha la cabeza y sumérgete), dijo John McWethy, y corrió zigzagueante como un conejo hacia la tanqueta que lo llevaba al campo de aterrizaje de helicópteros; desde ahí fue trasladado y subido a bordo de una nave de guerra que cruzaba delante de la costa. Durante el desayuno, vi en el noticiero del ABC el reportaje transmitido por teléfono desde Monrovia por el corresponsal del Pentágono; decía haber escapado con peligro de vida desde su hotel, tomado por bandas de asesinos. “Are you okay John?”, preguntó preocupada la presentadora del noticiero. "No dormí mucho la noche anterior, pero estoy bien”, decía McWethy. Después se insertó un mapa de la costa occidental de África, donde Monrovia estaba señalada con una flecha roja.

“Tú no eres periodista”, dijo Razouk, el propietario del hotel venido de Beirut a quien todo el mundo llamaba Papi, mientras le daba agua y azúcar con una pajilla a su papagayo enfermo. Después del estallido de los combates, el pájaro había perdido su plumaje y rechazaba el alimento. Yo esperaba en la recepción, con las maletas hechas, para pagar la cuenta. Razouk ojeaba mi pasaporte moviendo la cabeza. "Tú no eres un periodista alemán, sino un contrabandista de diamantes. Yo te conozco, tú no estás por primera vez en Liberia. Durante la guerra se hacen buenos negocios con los diamantes, pero es tremendamente arriesgado. Cuídate de que no te alcance una bala”.

Las circunstancias excepcionales modifican la sensación del tiempo. Mientras que en casa los días me parecen todos iguales — desde el desayuno hasta el noticiero televisivo nocturno-, en los territorios en crisis o en guerra tengo muchas más vivencias en un solo día que lo acostumbrado durante semanas y meses a mi regreso. Allá sólo puedo dormir unas pocas horas, y no me alcanza el tiempo para tomar notas y registrar lo que ocurre a mi alrededor. A eso se deben la sensación de vitalidad durante el viaje —el peligro surte el efecto de un golpe vitamínico- y de agotamiento posterior. 
Y mientras en casa el círculo de amigos y conocidos se reduce más y más, allá se cruzan en mi camino los personajes más locos, que parecen brotar directamente de la literatura: Don Quijote, por ejemplo.

El periodista de Buenos Aires no sólo se parecía al caballero de la Triste Figura, él era Don Quijote. La cabeza erguida, con orgullo; el talle alto y delgado como un alfiler; un copete brillante teñido de negro azabache bajo el cual destellaban sus ojos grises; su piel curtida, como el cuero, por el sol y el viento. En lugar de una armadura de caballero, llevaba un traje azul de mezclilla con una hebilla plateada en el cinturón y una cruz de oro kitsch en su dorso velludo. Caminaba tan abierto de piernas que parecía escucharse el sonido de las espuelas, con la espalda anormalmente recta, como si los médicos le hubiesen adaptado un corset de fierro; o tal vez era una columna vertebral artificial en platino. Esto se debía a que se fracturó dos veces la nuca, me confió los primeros minutos de nuestra presentación: "I broke my backbone twice", la frase sonaba tan inverosímil que le pedí que me la repitiera. La primera vez que se rompió la columna vertebral fue porque no se abrió su paracaídas, la segunda vez ocurrió durante un aterrizaje fallido con un parapente. Para tal extremo deporte, así como para Kosovo, Juan era en realidad demasiado viejo. Entre los reporteros y periodistas reunidos en la ciudad fronteriza albanesa de Kukës, en junio de 1999, que esperaban el ingreso de las tropas de la OTAN en Kosovo, él no sólo destacaba por su anacrónico traje de mezclilla sino por su avanzada edad. Ninguno de los otros superaba los cuarenta años, Juan tenía más de sesenta. Cuando cometí el error de preguntarle la edad, reaccionó con mal humor. Había olvidado que los porteños —así llaman a los habitantes de Buenos Aires - se tiñen el pelo en salones de peluquería, donde también se maquillan y se hacen la manicura como las señoras. En venganza me dio la receta de su delgada figura: "no colesterol", gruñó Juan en su inglés argentino, "because I don't want to get fat". El secreto de su régimen consistía en no comer platos con harina, leche o huevos, nada de hidratos de carbono ni grasa. Cuando le pregunté, “¿Qué es lo que queda entonces?”, me dijo: "bistec y ensalada”. Eso es “típico argentino”, pensé yo y retorné a mi pizza medio deshecha que servían de mañana, de tarde y por la noche en el bar americano. No había otra cosa. Eran las siete de la mañana, Juan iba de mesa en mesa por el comedor del hotel buscando una oportunidad para compartir un auto, todos los disponibles estaban reservados desde hace días. A los jóvenes reporteros les parecía sospechoso, tal vez sólo porque hablaba un mal inglés. Yo le ofrecí una plaza que había quedado libre de la noche a la mañana, decidimos compartir los gastos y sellamos nuestro acuerdo con un café. 
Juan trabajaba para un periódico argentino cuyo nombre no puedo recordar. Solamente después me vino la sospecha de que no era un periodista profesional, sino un aventurero que vino de Buenos Aires a Tirana por su cuenta; había llegado en taxi a Kukës to look for some action, como él decía.

En lugar del chofer con el que yo me había entendido el día anterior, apareció otro individuo que aseveraba ser el hombre indicado. Conducía un Mercedes Benz con matrícula de Stuttgart que él o su primo, camuflado detrás de las gafas de sol y sentado en el asiento trasero —emparentados como todos los kosovares_- habían comprado o robado, trayéndolo a Albania por caminos clandestinos. No poseía documentación del auto, tan sólo la green card de un seguro emitida a otro nombre. Para nuestro chofer, su Mercedes estaba en primer lugar: la guerra en Kosovo, la intervención de la OTAN y la presencia de la prensa servían solamente para el desplazamiento de su coche —al igual que en la novela de ciencia ficción de Kurt Vonnegut junior The Sirens of Titan, cuyo relato sobre la construcción de las pirámides, las Cruzadas y el desembarque de Napoleón en Egipto, son sólo informaciones codificadas para señalar la avería de una nave espacial perdida en el cosmos: Pieza de repuesto en camino; estamos llegando.

Después de atravesar la frontera, en viaje por tierra de nadie, le pregunté al chofer, mientras contorneábamos cráteres socavados por minas o bombas, si había tenido miedo. Miedo por su vida no, dijo él, después que su primo Halil tradujo la pregunta, pero sí por una raya en la pintura de su Mercedes. El grado de seriedad con que realmente estimaban el peligro quedó en evidencia cuando nos cruzamos en la ruta de Prizren con un convoy de camiones del ejército yugoslavo; los soldados en retirada hacían gestos obscenos y uno disparó al aire al pasar, pero el convoy continuó su marcha sin controlar los documentos de nuestro vehículo. El chofer agradeció a Dios — ¡Hamdulillah! — mientras su primo se quitó las gafas oscuras para secarse la transpiración de su frente.

A la entrada de Prizren, doblamos a la derecha y nos detuvimos delante de una casa con jardín en la que se escuchaban unos ladridos. Un gigantesco San Bernardo — quizá pudo ser un pastor albanés— saltó sobre Halil moviendo la cola, lamiéndole las manos y la cara. De una ruina ennegrecida por un incendio salió un hombre viejo que abrió el portón. El chofer nos invitó a pasar la noche en su casa; junto con su primo, limpiarían la basura dejada por los serbios; era más seguro aquí que en la ciudad controlada por la milicia. Don Quijote no estaba de acuerdo: la casa estaba demasiado sucia y ordinaria, él prefería pasar la noche en el hotel y cenar en un buen restaurante; tenía ganas de comer un bistec, pues desde el desayuno no había ingerido nada. 
En vano intenté explicarle que como consecuencia de la guerra en Prizren no había hoteles ni restaurantes. Don Quijote se obstinó en su punto de vista. El chofer nos llevó al check point de la Bundeswehr, cuya vanguardia de unidades blindadas había avanzado entretanto hasta el centro de la ciudad. A la mañana siguiente se confirmó que Juan había tenido razón: en el transcurso de la noche milicianos serbios minaron la casa. Al orgullo de casta de Don Quijote no le debo solamente la vida sino un opíparo ágape. En alusión a su estómago vacío, el argentino encargó a nuestro chofer requisar el último pollo que se pudiera hallar en Prizren. Bajo las miradas envidiosas de la mesa vecina, compartimos con nuestros amigos kosovares el pollo asado al palo y lo acompañamos con una botella de un litro de vodka; el ejército yugoslavo había saqueado las reservas de vino antes de su retirada. “El Ladrón de Gallinas de DIE ZEIT”, titulaba a la mañana siguiente el periódico berlinés Tageszeitung, cuyo corresponsal para los Balcanes había tenido que conformarse con galletas. Después de la comida nuestros caminos se bifurcaron, Juan se incorporó a un equipo de la TVE, cadena de Televisión Española. Le había gustado la asistente del camarógrafo, de veinte años, y Don Quijote juró a los dioses que Dulcinea sería el amor de su vida.

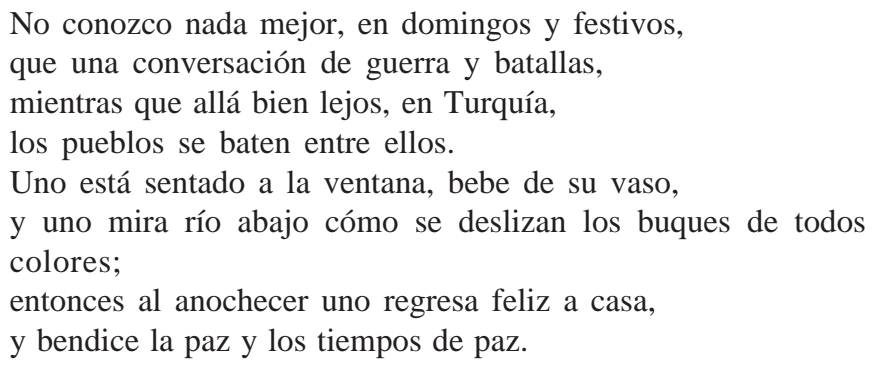

El confort fariseo de los pequeños burgueses del Fausto de Goethe ya no es posible hoy día. Las redes globales de los medios transmiten en vivo y en directo a sus livings los combates que se desenvuelven "allá bien lejos, en Turquía”, y los refugiados de Kurdistán o Kosovo golpean a nuestra puerta días más tarde, solicitando asilo político. "Vagabundo y errante serás en la tierra”, se dice en la historia de Caín y Abel; como en Kosovo o con los kurdos, la guerra comienza con derrame de sangre inocente. A través de este veredicto irrevocable, el enfurecido Dios del Antiguo Testamento ha definido más que una condition humaine atemporal: cada masacre y cada genocidio del siglo XX desatan una nueva ola de refugiados. En el umbral del Tercer Milenio hay tantas categorías de "vagabundos y errantes en la tierra” que la lengua capitula ante la sombría realidad, su vocabulario 
no alcanza a designar causas y efectos: expulsados externos e internos; solicitantes de asilo y falsos beneficiarios del derecho de asilo; trabajadores inmigrantes y emigrantes a causa de las crisis económicas; evacuados a último minuto, personas desplazadas y boat people, etcétera. Muchos habitantes de los Estados industrializados se sienten sobrepasados por la simultaneidad; confrontados diariamente con las consecuencias negativas de la globalización — miedo de una revolución social y tecnológica, crisis económicas y catástrofes ecológicas—-, su receptividad para la miseria ajena disminuye, mientras la alegre utopía de los años 80 , el sueño de una sociedad civil multicultural, va quedando en el camino.

"Considerar la posibilidad del derrumbe de la civilización es algo muy distinto que verlo cumplirse en la realidad”, escribió Klaus Mann en 1949 bajo la impresión de las ciudades destruidas de la Segunda Guerra Mundial. “Ciertas escenas e imágenes apocalípticas que al estudiante de filosofía en Kansas City o al poeta de Johannesburgo les parecen lejanas y fantásticas, por cierto increíbles, son muy familiares para los habitantes de Berlín, Varsovia, Dresde y Rotterdam”. Hoy en día es al revés: en las townships de Johannesburgo o en el ghetto de negros de Kansas City, la tasa de asesinatos es tan elevada que el Apocalipsis corresponde allí a la vida cotidiana, mientras que en Berlín y Varsovia, Dresde y Rotterdam, los habitantes han suprimido de su conciencia la destrucción de la guerra.

Lo que se filtra de las olas diarias de información lo deciden los medios: no a fuerza de manipulación o de censura - la cifra de muertos en Argelia o la de cesantes en Nuremberg no está manipulada por falsificadores de noticias_-, sino según la coyuntura de mercado. Para ser más preciso: según la ley de la oferta y la demanda. Los secuestros de aviones o de personas en los que estén involucrados turistas alemanes, interesan naturalmente más a los telespectadores de la República Federal Alemana que cuando se trata de víctimas y victimarios filipinos. Asimismo, los Estados industrializados no se interesan por guerras desatadas en regiones del mundo que no se vinculan con sus intereses estratégicos o económicos. A esto se añade un fenómeno que tiene que ver con la naturaleza misma de los medios más que con el mensaje que ellos transmiten: para que un acontecimiento aislado franquee el umbral de percepción del público y alcance el rango de una noticia permanente, es preciso que la información se concretice en una noticia, la que debe repetirse una y otra vez para que llegue a transformarse en un hecho establecido; este mecanismo es suficientemente conocido por la publicidad. Pero no es todo: depende del énfasis $-\mathrm{y}$ de la cantidad de espacio y tiempo- con que el redactor trate el tema. La retórica de los antiguos anticipó y analizó este fenómeno mucho antes de que nacie- 
ran los medios modernos. Para definir la transición desde el breve despacho de dos líneas hasta el reportaje que cautiva emocionalmente al lector, Quintiliano entrega un ejemplo y regla a la vez:

Sin duda, la noticia de que una ciudad ha sido saqueada expresa todo lo que el destino conlleva, pero a causa de su brevedad, ella no penetra con suficiente profundidad en los sentimientos del auditor. Pero si se libera aquello que está encerrado en las palabras, entonces emergen las llamas que se elevan de las casas y los templos, el estruendo de techos que se derrumban, y los gritos de todas las voces se condensan en un único sonido; los unos buscan su salvación en la fuga, los otros se aferran estrechamente abrazados a sus parientes; mujeres y niños lloran y los ancianos maldicen el destino que les ha mantenido en vida hasta este día... (Quintiliano: Retórica).

Los redactores de periódicos alemanes proceden al revés de los maestros de la antigua retórica: desde su punto de vista, todo lo que un autor escribe es muy exhaustivo y debe ser reducido hasta que el reportaje se vuelve un breve despacho. Lo que se llamaba antes colorido local, la descripción atmosférica del tiempo y del lugar, vale por quantité négligeable, porque a los lectores supuestamente les interesan sólo los facts: nada de faite divers (diversos hechos) recogidos del ir y venir de rumores sino facts duros, no crudos, sangrientos y coriáceos como un bistec a las brasas. Y cuando las víctimas, testigos oculares o sobrevivientes de un conflicto, toman la palabra más de una vez, se coloca una corta frase citable en soundbit que puede resumirse en dos o tres palabras; declaraciones contradictorias podrían confundir inútilmente al lector, quien supuestamente no es capaz de discernir entre hutus y tutsis. Quizás ésta es la razón por la cual raramente se leen en los periódicos de lengua alemana reportajes que van más allá de la superficie de las cosas. El archivo de prensa tiene mayor validez que el relato de la evidencia in situ; las informaciones múltiples, a veces remasticadas de segunda o tercera mano, aparecen más serias que la experiencia subjetiva y personalmente vivida, con su grado de incertidumbre. Análisis sociopolíticos que pueden redactarse en el escritorio de la casa toman el lugar de la observación precisa proveniente de la realidad. La primacía del conocimiento académico por sobre la observación empírica es un legado del Estado autoritario. No es de asombrar que el reportaje como género literario no haya surgido en Alemania o Francia sino que provenga del mundo eslavo y anglosajón: de Chéjov a Orwell, pasando por Hemin- 
gway, hasta Ryszard Kapuscinski y Joan Didion; Egon Erwin Kisch y Marie Luise Scherer son célebres excepciones que confirman la regla.

Pero no quiero sumarme a las críticas de mi país, tan en boga entre los intelectuales alemanes, pues no se trata de un problema político sino más bien estético. Me refiero al "arte poética” de la literatura de consumo masivo que, inadvertida, ha proliferado en el periodismo cuando éste adopta la forma narrativa: el punch-line al inicio del texto, como un anzuelo para seducir al lector con una dosis suficiente de sex and crime, hasta el efecto inesperado del punto final que penetra en el cerebro como un sacacorchos. Así es como debe sorprender, claro que sin ser osado ni realmente chocante. Se trata en general de no subestimar ni sobrepasar demasiado el horizonte promedio de experiencia que se les atribuye a los lectores. Una mezcla precisa de lo ajeno que despierta la curiosidad y un efecto de reconocimiento que la satisface: modelos narrativos convencionales de los años 50, acervo cultural desmoronado, al que corresponde también Ernest Hemingway, cuyas frases cortas y diálogos lacónicos han caído a la literatura de pacotilla, reapareciendo en numerosas novelas ilustradas y artículos de periódicos. Y eso que en la época de Hemingway ya era difícil establecer la diferencia entre un cuento y un reportaje. Las palabras Fakt (hecho) y Fiktion no sólo tienen un parentesco etimológico: el corresponsal para el sureste asiático de la Far Eastern Economic Review me confió en privado que, por años, él incluía en cada uno de sus artículos la misma descripción de la naturaleza, en la que se hablaba de estelas de polvo rojizo y sombras de nubes que se desplazan por encima de las montañas. Esto no sólo había pasado inadvertido ante el editor, cuya capacidad de reacción había puesto a prueba, sino que, por el contrario, éste cada vez lo elogiaba por su impresionante descripción. Como el fenómeno del déjà vu: detrás de la fachada del informe periodístico se deja entrever un paisaje arquetípico compuesto de fragmentos de escenografía, novelas de viajes y de aventuras.

En abril de 1997 me encontré con el caballero de industria Felix Krull. Él estaba en la antigua África oriental alemana, en Goma, en la ribera del norte del lago Kivu, donde el ejército del comandante insurgente Laurent Désiré Kabila había establecido su cuartel general — después de haber conquistado Kisangani en el curso superior del Congo - con el propósito de avanzar en marcha forzada a Kinshasa y mandar al diablo a Mobutu, el odiado dictador que lleva su mismo nombre: Désiré. Pese al sol abrasador, que reverbera los campos de lava de los volcanes adyacentes volviendo insoportable el calor, Felix Krull llevaba siempre una camisa alba recién planchada y un pantalón de lino con una hebilla de oro en el cinturón en forma 
de clave musical. Era alto y delgado; en la calle las muchachas jóvenes se daban vuelta a mirarlo y mujeres casadas le lanzaban elocuentes miradas. Sólo sus canosas sienes indicaban las décadas que habían pasado después de que Thomas Mann plasmara su historia en papel.

Como Felix Krull es un estafador de profesión, no le pregunté qué era lo que le molestaba en Europa como para marcharse al África oriental. A diferencia del personaje de Thomas Mann, había nacido y hablaba un francés entrecortado con acento renano de Hesse, una ciudad famosa por la sidra de bajo precio. Su inglés también era rudimentario. Pero él se hacía comprender sin palabras, por medio de miradas y algunos gestos. Y nadaba como un pez en las aguas peligrosas del África oriental contorneando diestramente los arrecifes y profundidades. Félix Krull estaba acostumbrado a dar órdenes: no se encontraba en el Tercer Mundo por primera vez y sabía que cada uno vale en tanto sabe hacerse valer. Pese a su habilidad diplomática, más bien reforzada que debilitada por su limitación lingüística — ya que el laconismo en África es sinónimo de autoridad—, se le iban acumulando dificultades inesperadas. Una organización humanitaria de renombre, cuya falta de profesionalismo disfraza con un activismo ciego, le había enviado con un cargo poco claro y mal preparado a Goma, donde un oficial del ejército insurgente dejaba pudrirse en un hangar cerca del aeropuerto víveres y medicamentos enviados desde Alemania. El jefe de la organización humanitaria le había dado poder general, porque Monsieur Jean, así se llamaba el oficial insurgente, había estudiado administración de empresas en Aquisgrán y hablaba fluidamente el alemán. Monsieur Jean guardaba bajo llaves el pasaporte de Felix Krull negándose, siempre bajo nuevos pretextos, a devolvérselo. Todo esto era un montaje para confiscar las mercaderías y los dólares que Felix Krull llevaba consigo para realizar su misión. "Su impaciencia es típicamente alemana”, solía decirle Monsieur Jean, “¿Para qué necesita usted un pasaporte? Disfrute del panorama de las montañas al borde del lago Kivu, y aclimátese aquí con nosotros. ¡En su patria tampoco anda por todos lados mostrando su pasaporte!"

De esta situación en jaque sólo había una escapatoria: la fuga hacia delante. Felix Krull telefoneó a la oficina de la organización humanitaria en Alemania y explicó su dilema. Propuso abandonar Goma y transferir el centro de sus actividades al extremo sur del lago Kivu, a fin de poder suministrar víveres y medicamentos a los refugiados que deambulaban errantes. La respuesta llegó con retraso porque el jefe de la organización humanitaria se encontraba, como siempre, de viaje. En compañía de Felix Krull, partí para Bukavu en su Land Rover. Sin visa en mi pasaporte - yo había franqueado ilegalmente la frontera y, en lugar de acreditación, poseía solamente 
una carta de la redacción de un periódico de Hamburgo en la que se que solicitaba facilitar el trabajo de sus corresponsales enviados al África-, atravesé con él pueblos incendiados y bases militares abandonadas. Un país destruido por la guerra, donde recientemente el ejército y los insurgentes habían librado violentos combates. A medio camino, el vehículo se hundió en el lodo hasta el tapabarro. Felix Krull lo puso en marcha, sin que quedara una sola mancha de barro en su albo pantalón, con la ayuda de la población autóctona que, según él, arrojaba agua sobre la pista todos los días para que los autos se atascaran al pasar —ésa era su principal fuente de ingresos. Nos detuvimos en un mirador sobre el lago Kivu. Mientras yo gozaba del panorama del paisaje, Felix Krull timbraba una falsa visa en mi pasaporte. Para eso llevaba en la guantera de su coche un juego completo de falsificador, siempre a punto para ser usado y al alcance de la mano; tenía tijeras, pegamento, emblemas nacionales y timbres, incluso una cámara polaroid para sacar fotos de pasaporte. Cuando retomamos la ruta, me explicó su concepto de marketing para la ayuda humanitaria: ésta debía concentrarse en lo que realmente importaba en África; en lugar de víveres y medicamentos que costaban fortunas y que finalmente se estropeaban o desaparecían sin dejar huella en los largos caminos de transporte, debían repartirse souvenirs, insignias y adhesivos, gorras, camisetas, lápices y encendedores con el emblema de la organización humanitaria. De esa manera sería conocida más rápidamente que otros servicios de ayuda, eliminando la competencia en terreno. Krull lo ilustraba a su paso, como príncipe de carnaval; en cada pueblo que atravesábamos, lanzaba banderitas de papel negro-rojo-dorado y globos con el logotipo de un grupo farmacéutico suizo que tenía formidable aceptación.

En Bukavu nos apropiamos de una casa quinta al borde del lago, arrendada por el servicio auxiliar de la Orden de Malta, cuyos moradores habían sido evacuados al desatarse el combate. Los empleados de la casa, que por semanas no habían recibido ni salario ni alimento, saludaron a Felix Krull como un salvador, y la cocinera negra, radiante de alegría, hizo las compras en el mercado. El regreso de su chef - todas las mujeres con las que había estado relacionado en Bukavu lo trataban de chef, con admiración- produjo un destello de luz en el sombrío horizonte de su porvenir. En un paseo por el jardín, descubrí un cadáver a la orilla del lago. El hombre parecía estar muerto desde hace días. Estaba boca abajo en el agua, el gas producido por la putrefacción había inflado las mangas de su uniforme. Quise notificar a la policía o al ejército, pero Felix Krull se opuso: nos detendrían como sospechosos del asesinato y sólo nos pondrían en libertad pagando una fianza, después de haber tenido que responder una cantidad 
de preguntas desagradables. Me propuso resolver el problema a la manera africana, así, uniendo nuestras fuerzas arrastramos al muerto al terreno vecino, donde quedó colgando en el embarcadero.

Quedé empapado en transpiración y apagamos la sed en el antiguo círculo de oficiales belgas, que servía de cuartel general para los residentes europeos en Bukavu. Los colaboradores de un grupo farmacéutico suizo, que plantaban árboles para producir quinina, se reunían en el bar con los asistentes del servicio humanitario, esperando el regreso de la población que había huido a los bosques; la cifra de refugiados se estimaba en más de cien mil, pero nadie sabía algo preciso, pues los caminos y las rutas estaban minados y se habían vuelto poco seguros por las tropas esparcidas del ejército o de los insurgentes.

A la mañana siguiente, los empleados de la casa nos condujeron hasta un Mercedes Benz, estacionado en el patio, que habían recubierto con follaje seco para ocultarlo de los soldados saqueadores. Felix Krull requisó el coche; el estanque de su Land Rover estaba vacío y en Bukavu era imposible conseguir bencina, por lo que pensó que sería más fácil para mí atravesar la frontera del país vecino, Ruanda, en un Mercedes, pues ganaría en prestigio ante los guardias fronterizos. Me recomendó expresamente no responder ninguna pregunta, simulando que yo no comprendía el francés ni el inglés. Durante los controles en la frontera, yo leería la Biblia, y para desviar la atención de los soldados, debía comer galletas de chocolate. Los guardias fronterizos tenían hambre y, si me pedían algo, podía ofrecerles de mala gana una o dos galletas; no más, pues eso despertaría sospechas. No debía presentar papeles, y si me preguntaban por mi nombre y mi profesión, murmuraría solamente la palabra chef; chef de tout, jefe de todo acá.

Me convertí en el maestro Puntila y Felix Krull se transformó en mi criado Matti. Cruzamos la frontera a Ruanda, cerrada durante la guerra del Congo —entonces Zaire-, sin ser controlados; ni siquiera mostramos nuestros documentos en un auto que no nos pertenecía. Horas más tarde, después de llegar a Kigali, Felix Krull lanzó una mirada al joven lustrabotas que introducía los cordones en los ojetillos de sus zapatos de Budapest y murmuró: "El problema en África es la cesantía. La gente aquí no tiene suficiente trabajo”, como si el papel del criado Matti hubiera despertado la conciencia social del caballero de industria Felix Krull.

Un mes después de mi regreso a Berlín, recibí una llamada telefónica de su mujer. Felix Krull estaba en el hospital de Bukavu, había recibido un balazo en la cabeza y la organización humanitaria para la que había trabajado, se negaba a repatriarlo por avión con el pretexto de que él se había 
alejado sin autorización de su lugar de servicio. Felix Krull estaba sentado en un café cuando le alcanzó una bala perdida; por suerte su vida no corrió peligro. El proyectil quedó incrustado entre el cuero cabelludo y el cráneo, pero la policía le atribuyó la responsabilidad a la víctima y lo arrestó por posesión indebida de armas. Pasaron varias semanas hasta que fue liberado de la prisión y regresó a casa, donde un litigio con su empleador lo llevó ante los tribunales. Debido a sus prácticas poco serias, la organización humanitaria dio lugar a murmuraciones y Felix Krull fundó su propia obra de beneficencia que prometía ayuda "rápida y sin burocracia".

El trabajo de un reportero a veces se parece a una sesión espiritista: la probabilidad de estar en el lugar cuando un actor político pronuncie una frase histórica es tan mínima como conjurar el espíritu de Julio César o el de Napoleón haciendo girar la mesa. En su lugar piden la palabra demonios inferiores, canallas, locos y espíritus atormentados, que en vez de aclarar los hechos, contribuyen a su confusión. A la primera categoría corresponden los supuestos observadores de la Unión Europea que se dejaron caer en Bosnia, durante el verano de 1995, como bandadas de aves de paso. La comparación con gansos salvajes o cisnes no es casual, pues los observadores de la UE estaban vestidos de blanco, como profesores de tenis que andan todo el tiempo con sus raquetas bajo el brazo. Eran funcionarios ministeriales de distintos países de la Unión Europea, la central de Bruselas los había enviado a la antigua Yugoslavia para observar los sucesos de la guerra allí mismo. Cuando pregunté cuál era la diferencia entre los sucesos de la guerra y la guerra misma, un observador venido de Bonn me respondió que era exactamente como en la meteorología: las perspectivas de mediano plazo sobre el tiempo, a diferencia de los pronósticos de corto plazo y del clima de largo plazo. La actividad de los observadores de la UE consistía en escribir informes, y como se les había advertido no exponerse a ningún peligro innecesario, abandonaban rara vez su hotel, donde conversaban con los reporteros que regresaban de la zona de combate, invitándolos a un café o a un trago en el bar para recolectar información. Todo lo que se transmitía en la noche por televisión y que se encontraba a la mañana siguiente en los periódicos, ellos lo transmitían semanas más tarde en forma estrictamente confidencial a sus superiores. Cuando no estaban organizando una comida de trabajo para poner al día su información, jugaban tenis, chapoteaban en la piscina, o se invitaban mutuamente a sus partys. Motivos había más que suficiente: siempre alguien estaba de cumpleaños o un Estado miembro celebraba su fiesta nacional. Es inútil precisar que los observadores de la UE no trabajaban gratis: adicionalmente a su salario de 
funcionarios, recibían indemnizaciones por su expatriación y gastos de representación —el sacrificio que hacían por la UE les era reconocido generosamente.

$\mathrm{Al}$ reino de los demonios inferiores pertenecen a su vez los reporteros vedette, que como monarcas reinantes llegan con un séquito motorizado. No me refiero a las estrellas de cine y televisión habituales, como el actor Pierre Brice que acompañó a Sarajevo a un convoy de camiones cargados con vestimenta y víveres, y permaneció sentado todo el día en el hall del hotel en Split, desconocido y triste, porque nadie le pedía un autógrafo o una entrevista. Y eso que había estrenado su papel de Winnetou en la montaña, no lejos de ahí. Me refiero al héroe de Bagdad, el reportero de CNN Peter Arnett, a quien sus colegas llamaban el ladrón de Bagdad, ya que había eliminado a periodistas de la competencia denunciándolos a las autoridades iraquíes a fin de poder realizar reportajes exclusivos sobre la guerra del Golfo. No sé si es cierto, porque yo no estaba entonces en Bagdad. Cuando me encontré con Peter Arnett en septiembre de 1994 en Port-au-Prince, él estaba en la cima de su gloria, llevaba un tupé ridículo para verse más joven de lo que era, y hacía vida de salón todas las tardes en el bar del hotel Montana, sorbía cócteles de ron y durante noches enteras narraba sus proezas en Vietnam que le habían valido el premio Pulitzer. Después de una semana de espera en el hotel, Peter Arnett llegó a la conclusión de que la crisis de Haití era un gran bluff y que el gobierno de los Estados Unidos no planificaba una intervención militar. Presuntamente recibía su información directamente del Pentágono. En la mañana, después de la precipitada partida de Peter Arnett, desembarcaron los US Marines en el puerto de Port-au-Prince —el reportero vedette había quedado penosamente en ridículo.

Más importantes que los big shots (peces gordos) son los así llamados stringers, colaboradores locales a tiempo parcial que arriesgan su vida por un salario mínimo. Son literalmente competentes para todo, desde el arriendo de un automóvil hasta un helicóptero, desde la máquina de café hasta la sesión de entrevista. Como no gozan de inmunidad diplomática y ningún medio ni gobierno los protege, los lores de la guerra y los dirigentes políticos desencadenan su furia contra ellos cuando aparecen comentarios críticos en los medios. Según el cliché "la culpa la tiene el mensajero y no el mensaje”, numerosos stringers se convierten en víctimas de la violencia que informan. En Bosnia y Chechenia, la tasa de muertos entre colaboradores locales, intérpretes y choferes de periodistas extranjeros fue especialmente elevada.

En territorios en crisis o en guerra, héroes y mártires son tan escasos como en la vida normal, pero Nyenati Allison fue para mí un héroe: como 
stringer de la BBC comentaba por la radio todas las tardes a las cinco, en directo desde la capital, Monrovia, o desde la selva, la guerra tribal en Liberia. Él no hacía ninguna concesión en sus comentarios, pero los combatientes de todos los ejércitos de la guerra civil lo respetaban, pues la World News From Africa, de la BBC, era la única fuente de información confiable y objetiva del país. Por la ruta a lo largo de la costa que va a Buchanan, los soldados de las Tropas por la Paz Africano-Occidentales (ECOMOG) nos interceptaron en un puente flotante del camino. "Why did you look at the bridge?” (¿Por qué han mirado el puente?), dijo un nigeriano con cicatrices rituales en su rostro, mientras me apuntaba con su ametralladora cargada. “Next time I break your legs" (La próxima vez le romperé las piernas). Yo quise saber si la amenaza podía tomarse en serio. "Yes, it is" (Sí, así es) dijo Nyenati Allison, y ofreció cigarrillos a los soldados de la ECOMOG. "I recognize your voice" (Reconocí tu voz) dijo el nigeriano riéndose, "you are Nyenati Allison" (eres Nyenati Allison).

Y en lugar de confiscar el micrófono y la grabadora del reportero de radio, como nos había amenazado, le pidió un autógrafo. Como no había alojamiento en Buchanan pasamos la noche en las ruinas de una casa saqueada. Afuera se cruzaban disparos, se oían gritos y ladridos que se aproximaban en la oscuridad. "No me gustaría cambiar de trabajo" dijo Nyenati Allison, y ató el mosquitero alrededor de una columna de concreto, “Amo mi profesión".

El equivalente a los arrogantes periodistas estrella son las almas benefactoras, tan compenetradas de su misión humanitaria que el mundo exterior se les presenta como un obstáculo para la realización de sus proyectos benéficos. Las fronteras entre países y Estados, los gobiernos y ejércitos, y las mismas iglesias y organizaciones humanitarias que compiten entre sí son, desde su punto de vista, vallas erigidas artificialmente que deben eliminarse del camino con rapidez y sin burocracia a fin de que la ayuda alcance a llegar a los necesitados, aunque su capacidad de iniciativa deje que desear; para no hablar de su conocimiento de la cultura tradicional. Es sabido que la distribución gratuita de vestimentas, víveres y medicamentos destruye los procesos de producción y distribución locales y degrada a los que la reciben al rango de objetos. Es menos sabido que tras la caridad de las benevolentes almas, dirigida a los humillados y agraviados, con frecuencia se encubre un desprecio paternalista por los infortunados, comenzando por sus propios colaboradores que arriesgan sus vidas y que están deficientemente formados, mal pagados e insuficientemente protegidos. El punto hasta el cual una ayuda mal coordinada es contraproducente se pudo ver en noviembre de 1996 durante el éxodo en masa de los refugiados hutus 
provenientes de Goma. Los convoyes de camiones, cargados con artículos de ayuda humanitaria, bloquearon la frontera y en su intento de abrirse el paso aplastaron a muchos niños refugiados que debían recibir esa ayuda. A su vez, durante el verano de 1998, en el sur de Sudán, personas hambrientas fueron heridas y murieron aplastadas por los paquetes de víveres lanzados desde los aviones. A este género de cosas corresponde el bombardeo a los convoyes de refugiados durante la guerra del Kosovo, cuando los aviones de la OTAN, por error, diezmaron a la población civil que debían proteger de los ataques serbios; según el lema intemporal del general Westmoreland en Vietnam: "Para salvar Hue, tuvimos que destruir Hue".

Durante una visita a Burundi me encontré con el homólogo masculino de la Madre Teresa, un gurú de la caridad. Él estaba en una recepción de la embajada en Bujumbara, con motivo de la fiesta nacional alemana - 0 quizá se trataba de la "fiesta de la cerveza" bávara en octubre - y nosotros hacíamos fila ante el buffet. En honor a ese día había salchichas de cerdo con chucrut. Las salchichas enviadas en el avión del ejército de la República Federal venían exactamente contadas, dos por persona, pues los habitantes de Burundi se morían de hambre. Pese a que el personal de la cocina sugirió moderación, el hombre caritativo amontonó seis u ocho salchichas en su plato y cuando un cocinero alemán le explicó el reglamento, exclamó furioso que él había hecho tanto bien en su vida que tenía el derecho a comer tantas salchichas como quisiera, y desapareció en la oscuridad con una copiosa porción en su plato. Aun hoy resuenan en mis oídos las palabras del gurú, cuya voz se puso ronca a fuerza de protestas, terminando en carraspeo. A veces un buffet caliente o frío es más revelador que la crisis política más peligrosa: a la vista de salchichas de cerdo, el hombre caritativo perdió su compostura y mostró su verdadero rostro.

Los verdaderos héroes son diferentes: el arzobispo de Monrovia, Michael Francis, por ejemplo, creó un programa para la reinserción social de asesinos menores de edad, que se desarrolla en tres fases, en este orden: desarme, perdón y rehabilitación. En una ceremonia que se realiza bajo la dirección de uno de los más ancianos del pueblo, un sacerdote o mullah, el asesino adolescente, a fin de ser reintegrado en la comunidad, es castigado con una paliza por los parientes de sus víctimas. Los criminales lo prefieren así, señala el arzobispo Francis, al que se le asoman zapatillas Adidas debajo de la sotana. Yo quiero saber qué va a pasar con "Rebel King", un ex alumno de la misión de alrededor de veinte años de edad, cuya conciencia carga con cientos de personas, entre ellas dos monjas italianas, a las que se dice torturó a muerte. "Como ciudadano exijo una pena severa, señala el 
arzobispo Francis, pero como cristiano rezo por el bien del alma de Rebel King”.

El padre Mario, un sacerdote salesiano italiano que encontré en el sur de Sudán, es quien más me ha impresionado. El fanático de Cristo estaba parado con los brazos abiertos delante de las ruinas de su iglesia destruida por segunda o tercera vez por los fundamentalistas islámicos. En cada ocasión había abandonado Sudán por instrucción de sus superiores, poniéndose a resguardo en Roma y volviendo después a Sudán con el propósito de reconstruir la iglesia con sus propias manos. Sólo el muro externo detrás del altar había quedado en pie. Los miembros de la parroquia habían pintado frescos sobre el ábside, donde estaba representado San Juan Bautista en el desierto. Como no tenían pinceles ni tinturas, habían mezclado la tierra roja a base de laterita con agua, pintando con sus manos sobre el muro blanqueado a la cal: como los hambrientos en el sur de Sudán, Juan Bautista se alimentaba de saltamontes mientras a su alrededor pastaban cebúes.

Le pregunté si no temía por su vida. Mi italiano, o el inglés del padre Mario, debe haber sido tan deficiente que hablábamos desesperadamente sin llegar a comprendernos. "Si usted quiere comer pasta fresca", dijo riéndose, "vaya donde la hermana Gabriela a Gogrial. ¡Ella prepara los mejores spaghetti de todo Sudán!” Un cameraman de la RAI, la cadena de televisión italiana, que filmaba la escena, se golpeaba la frente con la punta del dedo: "Padre Mario perdió la razón”, me susurraba al oído. “idespués de cuarenta años en este país no resultaba asombroso!”

\section{IV}

Como los redactores saben que muchos lectores sólo leen las primeras frases de un artículo, el lenguaje que se emplea en nuestro periódico es conciso y preciso, concentrando la información más importante y actual al inicio del artículo. Nuestros reporteros reúnen la información y la envían a la central del Time en New York, donde se elabora bajo la forma de un memorándum. En seguida el texto es rescrito por varios autores hasta transformarlo en un artículo al estilo del Time, donde se prefieren verbos activos, frases cortas y certeras. A veces un artículo contiene también pasajes que sugieren al lector lo que debe pensar del contenido, pero finalmente es el redactor jefe quien se reserva el juicio sobre ello.

El periodista que investiga con perseverancia, hablando con la gente, aprendiendo a conocerla en su trabajo colectivo o 
en su actividad social, observando y analizando los procesos, forja una relación estética con las personas y los acontecimientos. Esto se caracteriza por el hecho de abarcar la personalidad entera, pensamiento y sentimiento, sobre una base que implica aprobación y concordancia. (...) En este sentido, se recomienda exigir que la personalidad del periodista esté marcada por la filosofía marxista-leninista, a fin de realizar la política del partido de la clase obrera y de persuadir a los lectores de los fundamentos de esta política.

Dos definiciones del trabajo periodístico diametralmente opuestas, pero que se corresponden como en un espejo: realismo capitalista y realismo socialista, venidos de EE.UU. y de la RDA de los años 80. Si se hace una abstracción de los diferentes contextos ideológicos, las dos declaraciones concuerdan en un punto central: el escamoteo de la realidad sensible y tangible tal como es aprehendida por la vista, el oído, el olfato, y que aniquilada por una interpretación prefabricada, no aparece más que como un factor de interferencia o como arena en el mecanismo. Estas prescripciones no ayudan al reportero en su trabajo en terreno; al contrario, le obstruyen la mirada, impidiendo el asombro elemental que inspira la realidad, la que es totalmente diferente a como aparece en sus divulgaciones ulteriores, ya sea desde uno u otro punto de vista ideológico. El siguiente texto se encuentra en una tumba de la dinastía Han, escrito por un estratega militar chino; con una actualidad sorprendente, confirma las vivencias que más de dos mil años más tarde tuve en Sierra Leona, Camboya y Chechenia, donde soldados hambrientos limosneaban a los periodistas, cigarrillos, aspirinas o cassettes de música:

El general debe tratar a sus soldados como si fueran bebés, cuidarlos como a niños regalones, respetarlos como a profesores honorables y pisotearlos sin piedad como a la tierra y el pasto. (...) Cuando se da la orden de combatir, los soldados lloran. Los soldados que permanecen sentados tienen su ropa empapada de lágrimas, a los soldados acostados les corren lágrimas por sus mejillas. (...) El general debe estar en condiciones de engañar a oficiales y soldados de tal manera que ellos ignoren todas las maniobras del ejército. Él ordena a sus tropas partir al frente en una fecha determinada y luego les corta la retirada, lo mismo que si después de que hubiesen escalado el muro les quitara la escalera. Dispone que las naves se quemen y se rompan las vasijas de campaña; conduce a sus soldados por aquí y por allá, como a un rebaño de ovejas, así ninguno de ellos sabrá adónde debe ir. 
A Bertolt Brecht le habrían gustado estas frases que recuerdan el refrán del cabaretista Karl Valentin, que antes del combate les dice a los soldados en su dialecto bávaro: “Furcht hams, blass sans!” (¡Ellos tienen miedo, ellos están pálidos!), indicación que el joven Brecht utiliza en su puesta en escena de Eduardo II de Shakespeare. El teórico militar Sun Bin, de quien proviene esta cita, sabía de lo que hablaba, pues no observaba las guerras tan sólo a buena distancia. Él vivió en la época de los "reinos guerreros”, alrededor de 350 a.C., y era discípulo del estratega Sun Tzu (también escrito como Sun Wu) con el cual fue confundido más tarde, y fue muy apreciado por Mao Tse-tung. El general en jefe de Wei, sabiendo que Sun Bin era intelectualmente superior, hizo que le quebraran sus rótulas y le tatuaran la cara para impedir que el soberano de Wei lo recibiera en audiencia. Pero el enviado del reino Qi reconoció el talento de Sun Bin como estratega, lo escondió en su carruaje y lo llevó escondido a Qi, cuyo rey quería nombrarlo como general. Entonces Sun Bin dijo: "Un discapacitado torturado no sirve para general”, y fue nombrado como consejero militar. Sentado en un carruaje, cubierto por un telón, le impartía consejos al soberano del reino Qi: “Quien desea resolver una querella, no debe implicarse en ella; quien intenta deshacer un nudo enredado, no debe tirar del hilo sin reflexionar".

"No mencione mi nombre", dijo monsieur Dupont de Montauban que desactiva minas en los alrededores de Siem Reap, antigua villa real de Camboya. "Escriba mejor sobre nuestro chef de section Suong Van, padre de cinco niños que arriesga su vida todos los días por cien dólares al mes, a fin de liberar a Camboya de sus minas. Es a gente como Suong Van que deberían dar el premio Nobel de la Paz y no a cualquiera de los filántropos europeos o americanos que nunca han tenido una mina entre sus manos y no saben distinguir una MD 82 B de una T 72 A”.

Estamos en la cima de Phnom Krom, una altura que domina la planicie del lago Tonle-Sap y que fue conquistada sucesivamente por las tropas del dictador Lon Nol, el Khmer Rojo y el ejército vietnamita. Todos ellos colocaron minas entre las exuberantes malezas de la pendiente, minas que no están indicadas en ningún mapa —no por mala intención sino por descuido. Por el momento, la colina está tomada por los soldados del gobierno democráticamente elegido del viceprimer ministro Hun Sen, y para protegerse de posibles ataques ellos han vuelto a minar sus posiciones. Delante de la pagoda que data del siglo XI han emplazado baterías de defensa antiaérea y ametralladoras, cañones que apuntan al lago que se evapora por el calor, como si de allí pudiese esperarse un ataque del Khmer Rojo. Un soldado en 
calzoncillos de color kaki enciende una pipa de hachís y observa en la penumbra, entre la bruma, las ruinas de la antigua ciudad real Ancor Vat, mientras un gong llama para la oración matinal a los monjes del monasterio budista vestidos con sus togas color azafrán.

"Hay dos maneras de eliminar las minas”, dice monsieur Dupont, que con su equipo ha desactivado 315.066 minas durante la guerra del Golfo y ha perdido "sólo" a dos colaboradores que desatendieron las reglas de seguridad en Kuwait: "De lo contrario ambos aún estarían con vida”, añade moviendo la cabeza. "Los ingleses y americanos hacen estallar las minas; nosotros, los franceses, preferimos el método tradicional y las desactivamos a mano.” Pregunto si monsieur Dupont tiene familia en Francia, si su señora se preocupa por él. "Para no preocuparse, ella tendría que haberse casado con un fontanero. Sin embargo, también yo soy una especie de fontanero y, como usted ve, aún conservo ambas piernas y cinco dedos en cada mano”. Monsieur Dupont dibuja líneas en la arena con un bastón. "Los vietnamitas eran profesionales”, añade a guisa de explicación. “Ellos sabían emplazar muy bien un cinturón de minas. El Khmer Rojo hizo una labor chapucera, y sus minas son especialmente traicioneras pues están esparcidas a la orilla de caminos y en los arrozales. Cuando un búfalo o un niño pisa una mina, procedemos de la misma manera: les preguntamos a los habitantes qué caminos son seguros y conducimos nuestra ambulancia lo más cerca posible de la zona de peligro. Después penetramos centímetro a centímetro en el terreno minado. El défricheur despeja la maleza sin rozar el suelo delante suyo. El détecteur registra con un detector de metal el terreno despejado y el sondeur introduce una sonda en las partes donde el detector registra un objeto sospechoso, aunque se trate de un casquillo o de una lata de conservas vacía. Como en una excavación arqueológica, cada centímetro cúbico de tierra es tamizado, hasta que todas las partículas de metales han sido apartadas. Recién ahí el tramo de terreno es declarado viable”.

Mientras monsieur Dupont explica el trabajo de su equipo, su chef de section Suong Van deja al descubierto un MD 82 B vietnamita y, a buena distancia de nosotros, desatornilla el detonador. La cápsula de plástico verde se ve inofensiva como una polvera o un trompo para niños, pero puede matar a personas. Hay 40.000 víctimas de minas antipersonales en Camboya y cada mes se añaden 200 más, cruelmente mutiladas por minas dispersas en todo el país y cuya cifra nadie conoce. Según las declaraciones de la ONU, serían hasta diez millones; el gobierno de Phnom Penh habla de tres a cuatro millones. A diferencia de Kuwait que quitó todas las minas colocadas durante la guerra del Golfo en un tiempo récord, Camboya, que no tiene ingresos del petróleo, carece de los recursos necesarios para desactivar las 
minas. A su vez, cada mina retirada por un experto es reemplazada por una nueva colocada por los beligerantes. Pese a los reclamos internacionales, el ejército y los insurgentes no están dispuestos a renunciar a este medio de combate. Recientemente, partidarios del primer ministro Ranariddh, destituido por Hun Sen, se jactaban de querer minar de nuevo el territorio fronterizo de Tailandia. “¡Ha perdido usted la razón!”, grita monsieur Dupont, arrancándome de las manos la cápsula de plástico, cuando, sin pensar, intento introducir el detonador en la apertura prevista ¡De este modo yo habría reactivado la mina!

Rodeados de niños mendicantes volvemos a nuestro jeep estacionado en la ribera del lago. Casas sobre pilotes (palafitos) y barcos-vivienda, gallinas que escarban el suelo, patos contoneándose y cerdos hundiendo el hocico en el lodo. "La gente acá es muy pobre", dice monsieur Dupont, mientras reparte bombones a los niños: "El Khmer Rojo masacró a muchos pescadores porque eran oriundos de Vietnam. Durante el período de sequía, no tienen nada que comer y roban todo lo que se les cruza en el camino. Utilizan los letreros de advertencia colocados por nosotros, "Danger Mines!”, como palas; el cordón que prohíbe el paso a la zona de peligro, como sedal para pescar, y extraen la pólvora de las minas para cazar pájaros y conejos. Siempre se producen accidentes. Hace poco, un hombre que asaba una serpiente en medio de un campo de minas fue herido gravemente. Por suerte nuestra ambulancia estaba cerca y pudimos asistirle con primeros auxilios".

Dos horas más tarde me encuentro en el hospital de Siem Reap, a la cabecera de la cama de un hombre de 46 años al que una mina le arrancó el pie derecho. Se llama Sapal y viene del pueblo Srepo, donde pisó una mina al borde del camino. Fue transportado herido en una carreta de bueyes durante tres días y al llegar al hospital se le tuvo que amputar el pie debido a la gangrena. No podrá volver a caminar, pues su pierna izquierda también fue impactada por el proyectil quedando rígida. La mujer de Sapal está sentada al borde de la cama, ahuyenta con un abanico las moscas que zumban alrededor del vendaje sangriento que envuelve el muñón de su pierna. Le pregunto quien ha colocado las minas: ¿'los soldados de gobierno, el Khmer Rojo o las tropas vietnamitas? La mujer de Sapal se encoge de hombros y su marido sacude la cabeza en silencio: no sabe, ni tampoco le interesa.

"Es más eficaz enfermar al adversario que matarlo", dice monsieur Dupont. "La víctima de una mina necesita un promedio de seis personas para su cuidado. Así las fuerzas enemigas se inmovilizan y, a diferencia de lo que ocurre con las bombas, ningún edificio se destruye. Las minas antipersonales son las armas nucleares de los países pobres”. 
Comprendo recién la cínica verdad de este comentario al visitar el taller de Handicap International, anexo al hospital, donde las víctimas de minas tornean las prótesis bajo la dirección de colaboradores para el desarrollo. Lon Sok Pheak, un soldado del ejército gubernamental, ignoró la regla fundamental de que jamás se debe apresurar en acudir a socorrer un herido, aunque éste grite a todo pulmón. En la tentativa de salvar a su camarada, él mismo pisó una mina que le mutiló sus pies y en el hospital le amputaron ambas piernas a partir de la rodilla. El joven de veintiún años recibe 65.000 riel, apenas 20 euros al mes, y sólo se puede desplazar penosamente por medio de un carrito construido por él mismo.

"Por favor, no escriba nada sobre minas", me dice el redactor jefe del semanario alemán que me envió a Camboya. "Ya tratamos ese tema. Usted nos debía comentar el estado de ánimo de la gente de ese país después de treinta años de guerra civil. En lugar de ello, usted escribió una historia sobre los buscadores de minas. Es lo mismo que si usted volviera del Ártico con un reportaje sobre los pingüinos. Los pingüinos son de la Antártica, no del Ártico”.

"Por supuesto, tiene razón. Hay algo que yo siempre le he querido preguntar: ¿usted nunca ha tenido miedo?”

La respuesta prefiero guardármela, pues dura más de diez segundos y sobrepasa el marco de una conversación telefónica. Sí, al partir hacia lo desconocido, el miedo se apodera de mí; pensar en el peligro que me espera en Bosnia o Chechenia, Ruanda o Camboya, me ha deparado más de una noche de insomnio. Es el miedo de la infancia ante lo inasible e incomprensible que acecha en la oscuridad. Los consejos bien intencionados de los colegas en el sentido de portar siempre un chaleco de antibalas y jamás abandonar la huella de los neumáticos al descender de un auto, ya que las zanjas podrían estar minadas, nunca ayudaron a disminuir este miedo; por el contrario. Pero al llegar, este temor se disipa, como ocurre con el miedo a volar una vez que se está en el avión. A mí mismo me sorprende hallarme tan frío y tranquilo. Incluso en medio de los silbidos de las balas, nada puede alterar mi serenidad. Ya sea por necedad o falta de imaginación — equivalen a lo mismo—, no he podido establecer una relación entre mi persona y los muertos o heridos que se me ofrecen a la vista. No he podido o no he querido imaginar lo que significa ser impactado por una granada o una bala, a pesar de ver a las víctimas ahí mismo. Tal vez detrás de eso se esconde una especie de superstición o la ilusión de ser invulnerable. Solamente horas después de las masacres de las cuales fui testigo, primero en Haití y después en Ruanda, me comenzaron a temblar las piernas y sentí náuseas de pensar con qué facilidad me podía haber impactado una bala de fusil o un golpe de machete. 
El peor de los miedos me venía ante la perspectiva de regresar a casa, ante las indefensas preguntas de amigos bien intencionados, ante la reacción del redactor jefe del periódico que me envió a la región en guerra. El enemigo más peligroso de un corresponsal de guerra no son los mosquitos que transmiten enfermedades contagiosas, ni las minas escondidas al borde del camino, no son los soldados o insurgentes que de manera arbitraria disparan a los periodistas, sino los redactores de los medios de comunicación para los que uno trabaja. He aquí un ejemplo.

Ludwig Thoma tenía la misma fisonomía con que imagino al escritor homónimo, un bávaro bon vivant que amaba la comida y la bebida. En vez de escribir farsas sobre niños revoltosos, realizaba reportajes para un canal de televisión privado sobre la guerra civil en la ex Yugoslavia, guerra que vivió y comentó desde la separación de Eslovenia, es decir, desde el comienzo. Hallándose casualmente en el momento y lugar en cuestión, se transformó involuntariamente en experto del caso de Yugoslavia, ascendió a senior war correspondent y encabezó la corresponsalía de guerra de su emisora y de los medios de comunicación alemanes en general, sin colegas de la competencia. Lo conocí en junio de 1995 en un hotel de Split frecuentado por los periodistas, mientras yo consultaba a varios equipos de televisión en busca de un motorizado que me pudiese llevar a Sarajevo, cercada por el ejército serbio. Thoma se ofreció espontáneamente a llevarme en su coche. En compañía de su camarógrafo polaco, un ingeniero de sonido y una intérprete, había recorrido en su Land Rover todas las repúblicas de la antigua Yugoslavia, y trató de disuadirme del viaje a Sarajevo, pues la artillería bosnio-serbia atrincherada en el monte Igman disparaba expresamente a los periodistas. Mientras recorríamos Bosnia en zigzag, pasando por fincas incendiadas y mezquitas bombardeadas, me iba narrando la génesis del conflicto, que él conocía en detalle y por eso se le hacía más difícil tomar partido; síndrome conocido como clientelismo, con el que frecuentemente me encontré en las regiones de guerra. Thoma no les temía a las barricadas emplazadas en la ruta por soldados armados, que él engañaba hábilmente con maniobras —o entregándoles cintas de video vírgenes_- ni siquiera temía a los comandos de asesinos del Ejército Nacional croata con sus uniformes negros. Lo que le producía dolores de estómago y noches de insomnio era el fatigoso 'tira y afloja' con su redacción, a la que llamaba por teléfono satelital dos veces al día para grabar sus reportajes y recibir instrucciones. La cadena para la cual Thoma trabajaba tenía mala reputación a causa de la superficialidad de su programación, compuesta de concursos interrumpidos con spot publicitarios de mujeres con senos desnudos, en 
que las imágenes de guerra surtían ahí el efecto de cuerpos extraños. La tendencia era reducir en lo posible los reportajes sobre la antigua Yugoslavia o suprimir el noticiero nocturno por completo. Como periodista competente, tanto en historia como en política, Thoma tenía la sensación de estarles lanzando perlas a los cerdos, y de arriesgar su vida inútilmente por reportajes que aburrían a sus superiores y que a nadie en su país le interesaba ver. "Estoy harto de esta farsa", gruñía furioso para sí mismo. Se podría decir que sobre el campo de batalla de la guerra civil yugoslava él libraba una extenuante guerra personal contra sus empleadores. Aunque no tomaba partido - para él todos los que participaban en las matanzas tenían la conciencia manchada-, simpatizaba con los habitantes de Belgrado, a quienes los medios de Occidente habían puesto en la picota. Más absurdo me pareció cuando escuché por la radio que al inicio de la guerra del Kosovo, Ludwig Thoma había sido arrestado por las autoridades yugoslavas como presunto espía de la OTAN. Eso fue en la primavera de 1999. De la noche a la mañana aquel periodista, lacónico y esquivo de la publicidad, se hizo famoso y fue festejado como un héroe por los medios de comunicación. Después de una detención de varias semanas, con interrogatorios de veinticuatro horas que agravaron su enfermedad del estómago, fue liberado gracias a una intervención diplomática y trasladado a Munich en un avión de la Bundeswehr, donde le esperaba una desagradable sorpresa: cuando descendió del coche, a la orilla del Ammersee, confirmó que su yate —el único lujo que Thoma poseía-, comprado con el dinero de su trabajo como corresponsal de guerra, había tocado fondo en el puerto. El bote se había desfondado y fracasaron todos los esfuerzos por remolcarlo a un dique seco. Eso, me dijo Ludwig Thoma al teléfono, fue peor que todos los interrogatorios de la Seguridad del Estado yugoslavo.

Yo comprendo su reacción, pues el más pequeño trastorno del equilibrio interno turba la percepción del mundo exterior o, como dice Zarathustra de Nietzsche: "La vida es una fuente de gozo; pero para aquel que habla por boca de un estómago indigesto — padre de toda aflicción—, todas las fuentes están envenenadas”. Comprobé conmigo mismo la veracidad de esta frase.

El 9 de febrero de 1998, a las siete de la mañana, subí a un bus que debía llevarme de Argel a Sidi Hamed, un pueblo cerca de Blida que había adquirido triste reputación después de una masacre perpetrada por fundamentalistas argelinos. Había dormido mal y tenía frío. Pese a las temperaturas primaverales, al aire libre y a la bufanda de lana que me había enrollado al cuello, yo chupaba pastillas para la tos y debía sonarme la nariz — de la 
que goteaba una verdosa mucosidad — cada dos minutos. Por suerte traía conmigo suficientes pañuelos de papel. Algo me había enfermado: quizás el virus de la gripe se había esparcido por el aire acondicionado del hotel El Djazair o a través del viento que soplaba nubes de polvo seco en las calles de Argel. Podía ser la desolada atmósfera de esta ciudad, aterrorizada por bandas de asesinos, en la que no podía dar un paso sin la vigilancia de la policía y del ejército — según decían, por mi propia seguridad. Los periodistas que abandonaban el hotel sin autorización eran perseguidos por policías como criminales aprehendidos en un delito infraganti, y, bajo custodia severa, devueltos al hotel. Contrariamente al año anterior, casi todas las mujeres andaban cubiertas con un velo y los pocos cafés y restaurantes que no habían cerrado por temor a los atentados de bombas, estaban poblados de barbudos fumadores compulsivos, que sentados durante horas delante de una taza de café hojeaban periódicos en los que fuera de las declaraciones oficiales no había gran cosa para leer. "ALGÉRIE - GUINÉE 1 : 0”, decía el titular de El Watan esta mañana; pudo haber sido también El Moudjahid. Al lado de una foto tramada de grano grueso del presidente de la República de Níger que llegaba a Argel en una visita amistosa, se podía leer que órganos de seguridad habían eliminado en la cercanía de Blida a cuarenta y cuatro terroristas, entre los cuales había varios emires: así les decían sus adversarios a los comandantes del ejército del GIA y del Frente Islámico de Salvación (FIS).

Lo que me enfermaba era la sensación de parálisis que me producían las mentiras que me contaban todos con quienes hablaba, desde el taxista y el garzón del café hasta los políticos de gobierno y oposición. El vocero de prensa del ejército me hacía esperar vanamente, día a día, para decirme que mi petición de conversar con los sobrevivientes de una masacre debía ser examinada por las autoridades competentes. Aquella mañana, de repente, llegó el momento, y el bus con los representantes de los medios partió zumbando, escoltado por vehículos militares y automóviles policiales con baliza y aullidos de sirena, por el sentido contrario de la autopista, pasando por nuevas construcciones sin terminar y por cauces de hormigón llenos de carrocerías de autos oxidados. Un pastor con su albornoz agitado por el viento atravesó la carretera mientras guiaba un rebaño de ovejas y el bus frenó chirriando; las ovejas se empujaban unas a otras, atemorizadas, mientras nuestros acompañantes uniformados cargaban sus armas por temor a una emboscada —en francés faux barrage, falsa barricada, tendida por terroristas islámicos. En el triángulo de la muerte —así se llama en jerga periodística la fértil planicie costera entre Argel y Blida - florecían cerezos, olivos y naranjos que se cubrían de hojas de un verde lleno de savia, en medio 
de las relucientes frutas amarillas, el viento fresco del invierno acercaba y hacía palpable las cimas nevadas del Atlas. La belleza de la naturaleza ofrecía un asfixiante contraste con la miseria de las personas; como siempre, me propuse visitar nuevamente la región una vez terminada la guerra, cuando el bus se detuvo en Sidi Hamed.

Durante el banquete que anuncia el último día del Ramadán, desconocidos habían asaltado el pueblo situado en la loma de la montaña y masacrado a 151 hombres, mujeres y niños en el interior de sus casas. También habían muerto dos terroristas que, rociados con bencina, fueron quemados vivos por los "patriotas" — así se llamaba el ejército de autodefensa del pueblo en las declaraciones oficiales. Entre ambos extremos, terroristas o patriotas, el ejército había hecho tabula rasa. Como siempre, la masacre comenzó con un apagón. Cuando los asesinos entraron en acción, los habitantes del pueblo estaban cenando totalmente a oscuras. Noventa minutos más tarde todo había terminado. La exactitud de la planificación del asalto era sospechosa; su precisión era de relojería, desde la explosión del poste de alta tensión hasta la retirada de los agresores, que antes de escaparse a la montaña habían minado casas y lanzado bombas incendiarias en el cine repleto de personas donde se exhibía una copia pirata de Titanic. Lo que volvía el asunto aún más sospechoso era que el ejército, alertado por los habitantes del pueblo, había renunciado rápidamente a la persecución de los fugitivos, so pretexto de que les era imposible distinguir si era un amigo o un enemigo en la oscuridad. En vez de eso, a la mañana siguiente, la aviación lanzó cohetes aire-suelo sobre una base de abastecimiento de los terroristas en la proximidad de Mefta.

Ninguno de los testigos y sobrevivientes quiere o puede dar información sobre el motivo del ataque y la identidad de los terroristas. Un hombre viejo, que trabajó de albañil en Chicago, me aparta para un lado y me susurra en inglés que él sabe quiénes son los agresores; uno de ellos sería natural del pueblo vecino. Al ver que se aproxima un policía de civil, interrumpe la conversación y me pide que envíe de su parte saludos a su hijo que trabaja en Alemania.

Aunque se hubiese sabido que el ejército o el FIS eran los responsables de la masacre, eso no habría cambiado nada ante el horror que sentí al ingresar a las casas de muros en construcción, donde numerosas familias de origen cabil vivían en un espacio extremamente reducido. Sidi Hamed es un pueblo pobre, no quedó más que una tierra quemada, el pilar de una puerta calcinada de donde colgaba un atado de corontas de maíz quemadas, un reloj mural perforado por las balas que se detuvo poco antes de las diez, al momento de la masacre. Una alfombra carbonizada sembrada con cuadernos 
escolares despedazados, fotografías a color de un calendario y suras del Corán, pinzas para el pelo, pulseras y, como siempre, zapatos de niños. Frazadas arrugadas, impactos de balas y huellas de granadas en los muros blanqueados a la cal. Lo que parece barniz negro o alquitrán es sangre coagulada. Lentejas secas y macarrones crujen debajo de mis suelas. Me agacho y recojo de la ceniza una cadena de perlas, no son legítimas, sino artificiales, debió pertenecer a una pequeña niña que la llevaba en su cabello o alrededor de su cuello. Al lado hay un pato de plástico amarillo, al recogerlo del suelo siento un chillido en la mano. "Eran 70 agresores", dice Miched Zerrouk, un desempleado de 35 años que perdió a su mujer y a su hija Aída, de diez años, en el ataque. El menor de sus hijos, Djelal, fue impactado en el ojo por una granada, la abuela murió por el shock. De los veintidós miembros de esta gran familia, sólo siete sobrevivieron a la masacre. "Estamos todos traumatizados", dice la profesora del pueblo al conducirme a través del cementerio a las tumbas recién cubiertas; aún no llevan los nombres, están consecutivamente numeradas. "Tenemos miedo de que la masacre se repita". "Violan a nuestras mujeres y raptan a nuestras hijas para que los emires las usen de esclavas sexuales. Los islamistas llaman a esto mariage de plaisir (Boda de placer). Me defenderé contra estos salvajes hasta con mi última gota de sangre”, grita Abbed Mohammed, de 73 años, veterano de la guerra de la Independencia, que confiesa haber matado a once terroristas en Sidi Moussa. "No le crea nada", dice el albañil de Chicago que me siguió por el cementerio. "El ejército ha organizado el asalto para desacreditar a la FIS. Por favor, no mencione mi nombre, si no tendré problemas". "They don't care about people”, añade en inglés, "just power and money” (A ellos no les preocupa la gente, sólo buscan el poder y el dinero).

Yo estaba estupefacto ante el océano de dolor, cuyas olas me reventaban desde todas partes, pero lo más deprimente era que durante mi jornada por Sidi Hamed había estado permanentemente preocupado por mi nariz goteante, advirtiendo con terror que mi provisión de pañuelos de papel llegaba a su fin. La percepción interior había suprimido la percepción exterior, la picazón en la garganta y las palpitaciones en las sienes dominaban todo lo demás. Me sorprendió mi pensamiento herético; al parecer, mi resfrío era más grave que la miseria de la gente que me rodeaba. Retrospectivamente me parece que detrás de esta reacción falsa y casi absurda se escondía una especie de autoprotección, gracias a la cual me podía resguardar del peligro del mundo exterior.

"La política en una obra literaria es como un disparo de pistola en medio de un concierto, una cuestión grosera, de la cual, sin embargo, no es 
posible desviar la atención”, escribe Stendhal en La Cartuja de Parma, y prosigue: "Nosotros hablaremos solamente de cosas muy viles que, por más de una razón, intentamos callar; pero estamos obligados a abordar acontecimientos que aquí corresponden porque son para el teatro, el corazón de los personajes ${ }^{\mathrm{xxvi}}$ ". El pasaje citado es revelador desde varios puntos de vista: tematiza la irrupción de la política en la literatura y trae a la memoria, no por casualidad, la sospechosa frase de André Breton que dice que dispararle a la muchedumbre al azar sería un acto artístico. La Cartuja de Parma combina dos modelos narrativos que hasta entonces habían existido estrictamente separados el uno del otro: la novela romántica, la historia de capa y espada, que, como Carmen o El Conde de Montecristo, se desarrolla en países mediterráneos de carácter exótico o entre gitanos, y la crónica política de la historia contemporánea, desde la Revolución Francesa hasta la derrota de Napoleón.

Cada uno de estos discursos era suficientemente conocido y no suscitaba interés. Sin embargo, al mezclarlos reaccionan como dos productos químicos, y aunque cada uno sea inofensivo, de su combinación surte un efecto explosivo. Como elemento detonador, destruyó la estructura de género literario tradicional contribuyendo a la irrupción de un nuevo tipo de novela, la novela contemporánea que reemplazó el Bildungsroman, la "novela de formación” pedagógica. Ya en los primeros capítulos, Fabricio, el hijo de dieciséis años de una noble familia italiana que no entiende nada de historia ni de política, asiste a la batalla de Waterloo y ve aquellas "cosas muy viles” de las cuales no puede “desviar su atención”:

La cara de Fabricio, muy pálida por naturaleza, adquiere un tono verdoso fuertemente pronunciado; la cantinera, después de haber examinado al muerto, dice como hablando consigo misma: “Éste no es de nuestra división”. Después alza la vista hacia nuestro personaje y estalla en risas. (...) "Acércate”, le dice la cantinera a Fabricio. “¡Desciende del caballo! A esto te tienes que acostumbrar. Sí, a éste le dieron en la cabeza”. Una bala que había penetrado al lado de la nariz, había salido por la sien opuesta, desfigurando el cadáver de una forma repugnante; lo había dejado con un ojo abierto.

“Desciende pues del caballo”, le decía la cantinera, “y dale un apretón de mano, para ver si él te la vuelve a apretar”xxvii.

\footnotetext{
xxvi Stendhal, La Chartreuse de Parme (Paris: Gallimard, 1948), p. 405. Citas traducidas de la edición francesa. Cf. Archipel de la Douleur, p. 311 y ss. (N. del T.).

xxvii Stendhal, La Chartreuse de Parme (Paris: Gallimard, 1948), p. 59. Citas traducidas de la edición francesa (N. del T.).
} 
Como Pierre en La Guerra y la Paz, novela de Tolstoi, que también narra las guerras napoleónicas, Fabricio es un civil que, salvo en la caza, nunca ha tenido un arma entre sus manos; él yerra como una gallina ciega en el campo de batalla de Waterloo sin comprender el peligro en que se encuentra. Sólo posteriormente deduce el significado de aquello que ocurrió en torno suyo:

Unos instantes después, Fabricio vio delante suyo, a veinte pasos, un campo sin arar que parecía haber sido sacudido de una extraña manera. Los surcos estaban llenos de agua y pequeños trozos negros de tierra muy húmeda saltaron hasta tres a cuatro pies de altura. Pasando a caballo, Fabricio observó este extraño proceso. Escuchó a su lado un grito sordo: dos húsares cayeron impactados por las balas, y cuando quiso dirigirles la mirada, la escolta había avanzado veinte pasos. (...) Se dijo a sí mismo, bueno, entonces estoy por fin en medio del fuego. Olí la pólvora. Ahora soy un verdadero soldado. (...) "Es la primera vez que me encuentro en una batalla”, le dijo al guardia. “¿Pero es ésta una batalla verdadera?” “Como quien dice. ¿Pero quién es usted ${ }^{\text {xxviii??” }}$

Para el autor, Stendhal, no se trata solamente de mostrar con ayuda de técnicas de distanciamiento la realidad de la guerra que no sólo conocía de oídas, pues como oficial de Napoleón había participado en numerosas campañas. Se trata de aquello que Georg Lukács caracterizó en su ingeniosa obra de juventud Die Theorie des Romans (La teoría de la novela), como incongruencia del mundo y del alma: el alma del protagonista puede ser más estrecha o más amplia que el mundo exterior; las dos no coinciden jamás, esta desilusión es una experiencia fundamental del arte y de la literatura modernas. Mirándolo así, el protagonista de Stendhal, Fabricio, tiene más parentesco con Werther que con Wilhelm Meister, y se aproxima más a Don Quijote que a Fausto, que siempre aspiraba a una meta definida:

Él tiene que ser un aventurero. Pero (...) el mundo en el que se encuentra, no está solamente lleno de vida, sino que su resplandor proviene precisamente de aquella vida que se activa en él en cuanto esencia única. De esta incomprensión del mundo surge, pues, la intensidad de su grotesca manera de proceder al abordarlo tan pronto: el reflejo de la idea se disipa ante el rostro enajenado del ideal petrificado. La verdadera

xxviii Stendhal, La Chartreuse de Parme (Paris: Gallimard, 1948), p. 64. Citas traducidas de la edición francesa (N. del T.). 
esencia del mundo como tal, su orgánica ${ }^{\mathrm{xxix}}$, adquiere, más allá de las ideas y en defensa de su existencia, su correspondiente posición reinante sobre todo lo demás. (Georg Lukács, Die Theorie des Romans, Berlín, 1920.).

Esto es más que la filosofía práctica de Bergson o que un hegelianismo de segunda mano; la teoría literaria se transforma en una finalidad en sí, en l'art pour l'art.

El viaje a una región en guerra se parece a una escala de Richter abierta, no hacia arriba, sino hacia abajo. Sin embargo, a diferencia del Dante, el descenso al infierno comienza con el ascenso al paraíso. En el avión, cada pasajero es un privilegiado, mimado por la azafata con comidas y bebidas, pero también hay escalafones: desde la primera clase hasta business (para gente de negocios) y finalmente hasta la clase económica; desde vuelos charter hasta el avión militar repleto de cajas y sacos de lona, que en lugar de asientos confortables sólo contiene sogas y cinturones en los que los civiles se enredan al igual que paracaidistas inexpertos. Luego sigue el helicóptero de combate que pasa como un trueno, a baja altura, por encima de un campo de hielo, mientras el fotógrafo suizo Urs Möckli se inclina por la escotilla abierta para fotografiar un pingüino emperador — su vida pende de mis puños apretados alrededor de sus tirantes. O bien el piloto de la selva noruego Hans Hansen, cuyo avión Cessna roza las copas de los árboles en las cimas de los bosques vírgenes, mientras extrema la velocidad hacia una planicie montañosa llamada tepui y sólo vira en el último segundo para mostrarme al pasar las inscripciones grabadas en la roca por los indígenas precolombinos. Estoy sentado tras él, pálido de terror, apretado entre los bidones llenos de kerosén, al igual que una bomba de tiempo, porque como no hay gasolinera en la selva, Hans Hansen la transporta en el cockpit.

Pero el individuo más extraño era Dale Lee Roark, norteamericano de ascendencia indígena, que como piloto con experiencia de vuelo en la selva era adecuado para este tipo de aventuras. Él vivía en la reservación cheyenne de Oklahoma — por razones fiscales, me decía él. Dale había comprado en Ucrania, por un precio irrisorio de 100.000 dólares, un avión de carga Antonow y, junto a Sacha, su copiloto ruso, lo había conducido de Kiev a Kenia. Lo vi por primera vez en la primavera de 1997, en Goma, ciudad de Zaire, donde Sacha me explicó que el vodka era el mejor remedio contra el sida, una enfermedad de moda, que sólo afecta a los occidentales 'debiluchos’; los rusos estarían inmunizados contra la epidemia. Más tarde, volví a

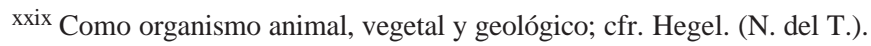


encontrarlos a ambos en Kisangani, al interior del Congo; los insurgentes contra Mobutu los habían enrolado como pilotos para transportar a su jefe Kabila por África, a donde él quisiera ir. En agosto de 1998, reencontré a Sacha y a Dale en Kenia, en el campo de base de las Naciones Unidas en la ciudad fronteriza de Lokichokio. Habían ganado una fortuna con los vuelos charter organizados para abastecer a la población hambrienta en el sur de Sudán.

Cuarenta y ocho horas más tarde Dale aterrizaba su deteriorada máquina Antonow 28 sobre una pista empapada por la lluvia en Rumbek, en medio de una región asolada por el hambre, y en la que debilitado por la fiebre y la diarrea yo esperaba poder trasladarme en avión a Lokichokio. Los pasajeros tuvieron que echar una mano y abrirse paso por los charcos, hundiéndose hasta las rodillas, para limpiar la pista inundada por el agua y el barro; bajo un calor pétreo despejamos con palas el tren de aterrizaje hundido en el lodo, y reunimos todas nuestras fuerzas para empujarlo de vuelta a la pista. Sólo al tercer o cuarto intento se encendieron los motores, y poco antes del despegue, mientras la máquina lanzaba torbellinos de agua sucia sobre la pista, un brazo extendido me alzó por la puerta abierta hacia el interior. Con la alegría de haber conseguido partir, el piloto arrancó su Antonov 28 a pique vertical y en altura ejecutó un looping que hizo volar el equipaje sobre las cabezas de los pasajeros. Cuando horas más tarde descendí del avión en Lokichokio, estaba congelado, me castañeteaban los dientes y tenía escalofríos. Por suerte, la mujer dinka, vestida tan sólo con un paño delgado y en estado de embarazo avanzado, que debió ser evacuada de la zona afectada por el hambre para recibir cuidados médicos, no sufrió un mal parto durante el vuelo.

"En el culo del mundo no hay un WC", dijo Sacha y orinó al borde de la pista ante los ojos de la mujer encinta. Pero estaba equivocado, pues en Lokichokio había un sistema de lavabo estudiado con un refinamiento sutil. Entre los contenedores que albergaban habitaciones y oficinas había un incesante ir y venir de empleados de las organizaciones humanitarias con rollos de papel higiénico bajo el brazo; se dirigían a los recintos de las duchas y WC, escondidos detrás de cercos de cactos y muros levantados a la estatura de las personas, separados por sexos y también por criterios religiosos y étnicos. Había baños para cristianos, musulmanes y africanos que preferían defecar parados en vez de sentados, como se decía, mientras que los hombres árabes elegían la posición sentada; por el contrario, las mujeres africanas orinaban paradas. Letreros con gráficas y placas en varias lenguas europeas y africanas explicaban la utilización políticamente correcta de los WC. En África occidental, vertederos, playas, desiertos y sabanas 
sirven de baños públicos. En Lagos nadie ve inconveniente en que alguien se baje los pantalones a la vista de todos en un descanso de la calzada para peatones, pero aquí todo estaba reglamentado, hasta el más pequeño detalle, por temor a que la violación de un tabú religioso pudiese enturbiar la coexistencia pacífica de las naciones reunidas en Lokichokio. Lo escribo porque nadie habla sobre esto; aunque la cuestión de los baños juega un papel primordial en la cotidianeidad de los corresponsales que recorren países del Tercer Mundo. Me viene a la mente aquel colaborador para el desarrollo que encontré hace doce años en el sur de Senegal, en Casamance. Él vivía en un pueblo de la etnia de los diolas para estudiar su arquitectura tradicional de arcilla, y pasaba cada fin de semana en el hotel de Cap Skirring — como me confió - para poder al fin defecar en paz. En el pueblo de los diolas no había baños, y cada vez que él iba a los matorrales a hacer sus necesidades, una docena de niños escondidos detrás de las plantas de anchas hojas y que lo habían seguido en secreto, lo espiaban para saber qué hacía ahí ese blanc (blanco); es imposible imaginar una deposición regular en esas condiciones.

Esto vale también para Chechenia, que se encuentra en la zona vertiente — geográficamente hablando, en el cruce- del "baño" ruso y del turco: ni el uno ni el otro fueron célebres por su confort. En las ciudades bombardeadas no había hotel ni restaurante, y me alojaba, como los demás periodistas, donde un lugareño en una casa de campo chechena, denominada Aúl. Una vez sentí la necesidad de un baño en medio de la noche, encendí un fósforo - la pila de mi linterna estaba vacía- y escalé por encima de mis guardias armados hasta los dientes, de puntillas y en calcetines, a fin de no hacer estallar una granada por un contacto involuntario. En la escalera me arrebocé con una piel de oveja sobre el pijama, me calcé las botas y, chapoteando en el barro hasta los tobillos atravesé el patio en dirección al establo de enfrente, donde según me habían dicho, se encontraba el baño. Escuché el resuello de una vaca y el chillido de un puerco; en 1995, la charia no había sido aún introducida y los chechenos comían carne de cerdo. Me acurruqué encima de la paja mientras en la oscuridad un animal invisible había comenzado a roer mis botas, probablemente un puerco, en cuyas emanaciones animales recalenté mis dedos entumecidos. La caminata al baño duraba diez minutos, sin contar la limpieza de las botas al final. Tan sólo al regresar descubrí, en la penumbra del amanecer, el lugar asignado para esta faena: una cabaña de madera con una ventanita en forma de corazón al pie de la escalera.

Dos horas más tarde me despiertan unos disparos de salva: no es un ataque del ejército ruso, como temí en un principio, sino la señal de una 
fiesta de boda chechena, semejante a una boda de campesinos pintada por Brueghel, sólo que las kalachnicov no calzan en el cuadro. Los boieviki disparan al aire de alegría, sin pensar que las balas vuelven a caer a la tierra; dos invitados son heridos por dos balas perdidas, una pequeña niña es alcanzada por una de esas balas en el muslo, pero eso es parte de una verdadera fiesta de boda. Mientras tanto la novia vestida de blanco, que ha sido simbólicamente secuestrada por los hermanos del futuro esposo, recibe visitas y regalos sin una palabra de saludo o agradecimiento; los ojos castos miran hacia abajo como corresponde a una virgen. Me llenan con bocados exquisitos y una robusta matrona canta una melodía improvisada acompañada por el acordeón, la letra narra la historia de un reportero alemán que vino a Chechenia para asumir el lugar del marido de dicha matrona, caído en la guerra. En vano explico que ya estoy casado, y sólo con esfuerzo logro escaparme de la boda.

En febrero de 1995, durante mi primera visita a Monrovia, tuve la sensación de haber llegado al último círculo del infierno. Eso que aún no había muertos en las calles, ya que los combatientes de la guerra civil habían convenido un cese al fuego y las casas de la ciudad todavía no estaban destruidas; en los mercados se vendían frutas y verduras y cada día había agua y electricidad durante algunas horas. Varios síntomas dejaban entrever el desmoronamiento del Estado, pero nada había de aquella alegre anarquía que imaginaron los estudiantes del 68, más bien lo contrario. El cuartel general de Trae Whig Party, fundado en 1869 por los esclavos liberados de los Estados Unidos y que gobernó a Liberia durante más de un siglo, había sido saqueado por los pobladores y reconvertido en un baño. (La palabra Whig no tenía que ver con pelucas, como yo supuse en un comienzo, era la abreviación de We Hope in God, tenemos esperanza en Dios.) El templo vecino, donde la elite de los americanos-liberianos celebraba sus rituales masones, había sido devastado; los azulejos de mármol estaban cubiertos de excrementos. Los ladrones habían arrancado la estatua de bronce de Tubman, que fue presidente durante muchos años, y sobre el pedestal del monumento sólo quedaban sus pies dentro de los zapatos de bronce, como una reliquia absurda.

El edificio de la clínica de obstetricia, construido en el período de gobierno de Tubman con los adelantos más modernos de la medicina occidental de aquel entonces, albergaba ahora a refugiados de guerra y personas desplazadas, que eran socorridos por la UNCHCR y alojaban en condiciones higiénicas infrahumanas. De las ventanas quebradas se agitaba la ropa colgada, los ascensores desbordaban de basura. Las salas de enfermos y los quirófanos, donde en otro tiempo enfermeras y médicos se habían 
inclinado sobre sus pacientes con instrumentos relucientes, ahora estaban divididos en minúsculos reductos separados con trapos sucios, en los que familias numerosas cocinaban, comían y dormían. El edificio repleto de displaced persons (personas desplazadas) se había convertido en una incubadora de epidemias y crímenes, y los refugiados estaban expuestos sin protección alguna a las represalias de los combatientes de la guerra civil.

En el punto más bajo de esta escala descendiente de Richter, que indica todos los grados de podredumbre y abandono, se encontraba el Ducor Palace, un antiguo hotel de lujo situado en la cima de una colina con vista sobre la bahía de Monrovia. En otros tiempos había sido la primera construcción de la ciudad. Un olor a materias fecales impregnaba escaleras y corredores, y en los muros recubiertos de moho goteaba el agua que faltaba en las duchas y en los baños. Los oficiales del ejército africanooccidental de intervención por la paz de la ECOMOG se habían alojado en los pocos cuartos aún habitables, y sobre la azotea jardín del hotel, la piscina llena de sacos de basura y de preservativos usados estaba custodiada por los soldados nigerianos.

"Usted ha cometido un error al digitar", dijo la redactora del periódico, a la que presenté semanas más tarde mi reportaje sobre Liberia. "Debe decir: la escala de Richter abierta hacia arriba". Le señalé en vano que el adjetivo latín altus significa, según el contexto, alto o bajo, y cité igualmente en vano los versos con los que Mefistófeles le explica a Fausto la formación de las montañas:

Teniendo hoy la cuestión por otro cabo, / pues lo que antaño fue del fondo ahora es cima. / Fundándose así la justa doctrina, / al invertir arriba por abajo ${ }^{\mathrm{xxx}}$.

La redactora permaneció indiferente: "Usted no es Goethe”, dijo ella con plena razón, y “no escribe en latín, sino en alemán”.

Al llegar a este punto, debo precisar lo que este libro no es:

1. No es un llamado a paliar la miseria o a una intervención militar.

2. Ni es una contribución para explicar el primero, segundo, tercero o cuarto mundo (valga cualquier cosa que pueda esconderse detrás de esta numeración).

xxx Estos cuatro versos de Faust II de Goethe, se relacionan con el espíritu del pensamiento místico medieval. Aquí se orientan por endecasílabos y consuenan en a-a-bb. Esta versión intenta dejar una leve impresión al conservar el sentido, el endecasílabo y los versos con asonancia en a-b-b-a (N. del T.). 
3. Ni es un reproche destinado a los medios de comunicación, ni una crítica a la censura o a la manipulación.

4. Ni es una acusación ante el Tribunal Internacional de Derechos Humanos de Arusha o de La Haya; ni tampoco una petición de financiamiento para aliviar a las víctimas.

5. Ni es un estudio del estrés postraumático; ni tampoco una sesión psicoterapéutica destinada a ferroviarios y bomberos que recogen cadáveres carbonizados y mutilados.

Si bien contiene algo de todo eso y aborda reiteradas veces estos temas, el texto no trata ninguno de ellos de una manera completamente satisfactoria. Quien busca respuestas a tales preguntas haría mejor en volver a cerrar el libro. Bien, ahora podemos continuar la conversación. (Éste es un homenaje a mi amigo fallecido Reinhard Lettau, que tenía la costumbre de reducir a la mitad el número de participantes en sus seminarios de creative writing en el sur de California, preguntando: “¿Quién de ustedes se interesa por novelas policiales? ¿Quién de ustedes se interesa por la ciencia ficción? Todos aquellos que levantaron la mano abandonen la sala, pues yo no enseño novelas policiales ni de ciencia ficción.”)

El texto aquí presentado no es un informe elaborado por un experto que da respuesta a supuestas preguntas técnicas. Como toda literatura que merece este nombre, plantea preguntas tan ingenuas que nadie las hace. La pregunta de Tolstoi, por ejemplo: “¿Qué es el coraje?”, o la que hace Fabricio (en la obra de Stendhal) después de la batalla de Waterloo: “¿Era esa una verdadera batalla?” La sabiduría de Sócrates consistía en saber que él no sabía nada, como Galileo Galilei en la obra epónima de Brecht: “¡Hombre de Dios!, yo no soy tan sesudo como los señores de la Facultad de Filosofía. Soy necio. No entiendo absolutamente nada. Estoy obligado a rellenar los vacíos de mi conocimiento”. (Aquí resisto a la tentación de añadir una digresión sobre la necedad de los intelectuales que no previeron el desmoronamiento de la RDA ni la caída de la Unión Soviética, sino que aseguraban, convencidos, que ambos Estados eran económicamente fuertes y políticamente estables. Yo prefiero hablar de mis propias estimaciones erróneas: 1989, después de la masacre en la plaza Tiananmen, creí que el proceso de democratización continuaría después de una corta interrupción, y tuve que ser instruido por un poeta disidente chino que me advirtió que un cambio de dirección en la línea del partido demora por regla general siete años. Y en 1995, después de mi primera visita a Monrovia, me atreví a emitir el pronóstico de que todos los protagonistas de la guerra civil liberiana estaban agotados y que el retorno a la paz era inminente; en ambos casos estuve trágicamente equivocado.) 
En un epílogo errático de La Guerra y la Paz, que aparece al final de esa novela monumental como un cuerpo extraño, Tolstoi adopta la perspectiva de un campesino iletrado que intenta en vano comprender qué fuerza mueve a una locomotora: ¿es el humo o el diablo, el mujik ruso que palea el carbón o el ingeniero alemán que aceita la máquina? Nada de todo eso.

Desde la perspectiva del campesino analfabeto, Tolstoi narra la historia de la humanidad "en un pequeño rincón del mundo que se llama Europa”, y especialmente aquel tramo de la historia europea que precede a los acontecimientos expuestos en la novela. La mirada extraña revela una verdad suprimida, que por ser tan elemental, escapa a la percepción del historiador, quien a fuerza de ver árboles no ve el bosque o a fuerza de ver el bosque no ve los árboles; ambos ejemplos acaban igual: “A finales del siglo XVIII, se habían reunido en París una veintena de personas que discutían que todos debían ser iguales y libres. De ello resultó que en toda Francia la gente comenzó a matarse y a ahogar en sangre a sus semejantes. Luego resurgió en Francia un genio, Napoleón. Él venció en todas partes, es decir, mató a mucha gente porque era un gran genio. Partió a matar, no se sabe por qué, a los africanos, y los mató tan limpiamente, y era tan astuto e inteligente, que a su regreso a Francia ordenó a todos obedecerle. Y todos le obedecieron. Apenas se había convertido en emperador, partió una vez más a matar a pueblos en Italia, Austria y Prusia. Y mató a muchísimos”.

"Sería vano pensar que todo esto que acaba de exponerse, corresponde a una burla o a una caricatura de los relatos históricos”, añade Tolstoi, a guisa de resumen. "Es, por el contrario, la expresión más delicada de estas contradicciones, que no dan una respuesta satisfactoria a las preguntas planteadas a lo largo de toda la historia”.

La genialidad de Tolstoi consiste en observar el mundo con los ojos de un analfabeto y poner en evidencia que el sentido de la historia, tomado como moneda legítima por los intelectuales de todas partes, no es sino un engaño y una falsa moneda: se trata de una convención práctica que nos ayuda a apartar de nosotros la idea inquietante de que se trata en verdad de una cadena de masacres absurdas —aquí este adjetivo muy gastado es adecuado. Sus necias preguntas son indicadores de caminos por una región aún no cartografiada, a diferencia del conocimiento de los autoproclamados expertos que avanzan sobre rieles trillados. Lo que aquí vengo diciendo no vale sólo para el campo del arte y la literatura, sino también para las ciencias y las humanidades — como lo atestigua Galilei en BrechtLe dejo una vez más la palabra a un escritor al final de estas reflexiones. Schlachthof 5 (Matadero 5) es el título de la novela de Kurt Vonnegut Jr. sobre la destrucción de Dresde por los bombardeos aéreos en la noche del 
13 al 14 de febrero de 1945. El autor vivenció aquello como prisionero de guerra, logrando salir ileso por casualidad, escondido en el sótano de un matadero. El libro trata de las dificultades de escribir una novela sobre un desastre provocado por la mano del hombre y que supera toda capacidad individual de percepción, y con ello toda posibilidad de empatía. Como todos los sobrevivientes, el narrador está traumatizado y le faltan las palabras adecuadas para dimensionar los acontecimientos, porque éstas no existen. Kurt Vonnegut se zafa del dilema con una ironía que linda en el cinismo; a finales de los años 60, época en que se publica la novela, esto se conocía bajo el término específico de humor negro:

Cuando regresé de la Segunda Guerra Mundial hace 23 años, pensaba que no me sería difícil escribir sobre la destrucción de Dresde, puesto que me bastaría con relatar lo que había visto. Contaba con que iba a ser una obra maestra o que, al menos, un tema de esa magnitud me reportaría una buena cantidad de dinero.

El recurso literario de Kurt Vonnegut consiste en abstenerse de todo juicio moral o político sobre los acontecimientos expuestos en la novela, y ceñirse permanentemente a la perspectiva narrativa de su personaje, un Simplicissimus ${ }^{\mathrm{xxxi}}$ moderno que, al igual que los protagonistas de Stendhal o Tolstoi, confía a expertos la evaluación de los hechos. Más importante que lo que el autor dice es aquello que permanece inexpresado, quedando así libre a la imaginación del lector. Desde esta perspectiva ética y estética, aparecen como dos caras de una sola y misma cosa ${ }^{\text {xxxii. }}$

"Eso tenía que ocurrir", dijo Rumfoord a Billy, a propósito de la destrucción de Dresde.

"Yo lo sé", dijo Billy.

“¡Esto es guerra!”

"Yo lo sé. No me quejo”.

xxxi Simplicissimus era una revista semanal satírica alemana, fundada por Albert Langen en abril de 1896 y que se publicó hasta 1944. Su título se inspiraba en la novela del siglo XVII: Der abentenerliche Simplicissimus, que combinaba un contenido descarado y políticamente atrevido con un estilo gráfico inmediato. Publicó artículos de escritores como Thomas Mann y Rainer Maria Rilke. (N. del T.)

xxxii Como conclusión del ensayo, el gesto de Kurt Vonnegut (1922-2007) tiene apoyo histórico-filosófico en el pensamiento estoico-escéptico. Vonnegut sostiene que no podemos llegar a conocer, en realidad, la diferencia entre las cosas. Por eso conviene abstenerse de todo juicio para alcanzar la imperturbabilidad anímica: la ataraxia. Cfr. Francisco Sánchez, Que Nada se Sabe (Quod Nihil Scitur), primera edición, Lyon, 1581 (N. del T.). 


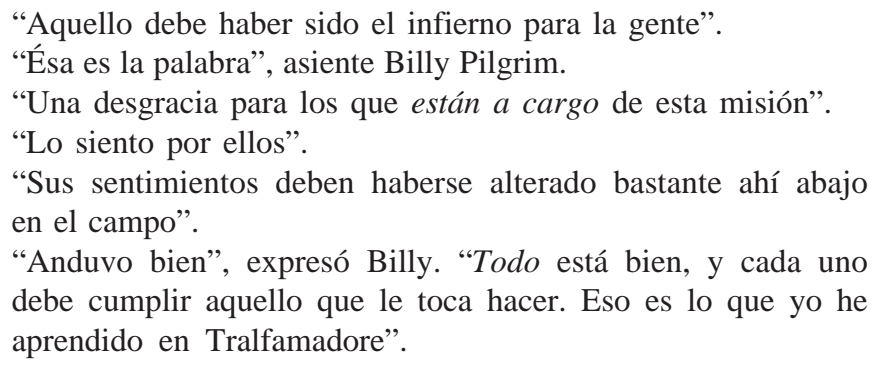

\section{SIGLAS Y ABREVIACIONES}

AFL: Fuerzas Armadas de Liberia.

ALIR: Ejército de Liberación de Ruanda. Miembros de la guerrilla tutsi.

Aprosoma: Avocación para la Promoción Social de las Masas. Movimiento anti-tutsi.

Boieviki: Miembros de la guerrilla chechena.

CEDEAO: Comunidad Económica de Estados del África Occidental.

ECOMOG: Grupo de Observadores Militares enviados por la CEDEAO.

FIS: Frente Islámico de Salvación. Partido musulmán fundamentalista de Argelia.

FNPL: Frente Nacional Patriótico de Liberia.

FPR: Frente Patriótico Ruandés. Movimiento compuesto por exiliados tutsis que invade Ruanda desde Uganda. El actual presidente de Ruanda Paul Kagame es miembro del FPR.

GIA: Grupo Islámico Armado. Grupo islámico extremista de Argelia.

GPU: Policía secreta estalinista.

KGB: Comité de Seguridad del Estado, en la ex URSS.

Khmer Rouge: (Khmer Rojo) organización comunista camboyana que tras la Guerra de Vietnam, la expulsión de los Estados Unidos y el derrocamiento del general Lon Nol, tomó el poder el 17 de abril de 1975 y fundó la Kampuchea Democrática (KD), un nuevo Estado comunista bajo la dirección de Pol Pot (Saloth Sar).

Interahamwe: Milicia extremista hutu, responsable del genocidio de tutsis en Ruanda.

INTERFET: Fuerza Multinacional en Timor Oriental. Tropas de intervención en Timor Oriental conducidas por australianos.

Milicia Krahn: Partidarios militantes del presidente liberiano Samuel Doe, asesinado en 1990, que ocupó las posiciones claves con miembros de su etnia, el Krahn. 
MSF: Médicos Sin Fronteras.

NKWD: Comisariado Popular del Interior, policía secreta estalinista. Organización sucesora de la GPU y antecesora del KGB.

ONU: Organización de Naciones Unidas.

OSCE: Organización para la Seguridad y la Cooperación Europea.

OTAN: Organización del Tratado del Atlántico Norte.

Pacto de Varsovia: Acuerdo de cooperación militar firmado el 14 de mayo de 1955 en Varsovia por los países del Bloque del Este, abarcando todos los estados socialistas de Europa del Este (Albania, Bulgaria, Checoslovaquia, Hungría, Polonia, la República Democrática Alemana, Rumania y la Unión Soviética) a excepción de Yugoslavia. La República Popular China estuvo afiliada al Pacto de Varsovia como observador. A partir de 1989, varios estados anuncian su retiro del Bloque. Su disolución oficial ocurrió el 1 de julio de 1991.

Parmehutu: Partido del Movimiento de Emancipación Hutu.

POUM: Partido Obrero de Unificación Marxista.

RADER: Unión Democrática Ruandesa.

RDA: República Democrática Alemana.

Stasi: (Ministerium für Staatssicherheit, abv.: MfS, o "Stasi”) Ministerio de Seguridad del Estado de la ex RDA. Agencia de servicio secreto del interior y exterior de la RDA.

UÇK: Ejército de Liberación de Kosovo.

UNAMET: Misión de las Naciones Unidas en Timor Oriental.

UNAMIR o MINUAR: Misión de Pacificación de las Naciones Unidas.

UNHCR: Alto Comisariado de las Naciones Unidas para los Refugiados.

UNR: Unión Nacional Ruandesa. Movimiento anti-hutu.

Palabras clave: violencia humana; guerra; medios de comunicación; ética periodística; periodismo literario. 